UCRL-53195

Distribution Category UC-70

UCRL --53195

DE82 011842

\title{
Preparation and Properties of Synroc D Containing Simulated Savannah River Plant High-Level Defense Waste
}

\author{
C. Hoenig \\ R. Rozsa \\ F. Bazan \\ R. Otto \\ J. Grens
}

Manuscript date: July 23, 1981

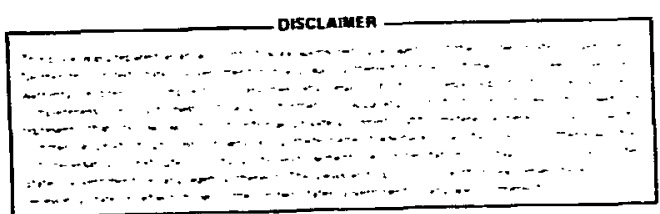

LAWRENCE LIVERMORE LABORATORY

Unit arsity of California • Livermore, California • 94550 
Foreword

Abstract

Introduction

Description of Savannah River Plant Hast:

The Comparative Leach Testing Program

Synroc D sormulations

General Background

Composite Waste Forms (S21, S29, S20) and Hollandites (s18, s03a)

ii

High-Iron Waste Forms (S26, S30) and Hcllandite (SAN)

High-Aluminum Waste Form (S31)

Waste Form Preparation

S29--The Reference Synroc D Composite Waste Form

Starting Materials

Slurry Preparation

Spray Drying and Calcination

Hollandite Preparation

Hot Pressing

Mechanical and Thermophysical Properties

Ultrasonic Elastic Constants

Flexural strength

Compression Sirength

Thermal Expansion

Thermal Conductivity

Microhardness

Leaching Characteristics

References

Appendix A.

Append ix B. 
FOREWORD

The information provided in this report summarizes the procedure for preparing the Synroc D test samples used in the Comparative Leach Test Program of FY81; results from some leaching, mechanical, and thermophysical property tests are also reported. As with any large experimental endeavor, the success of the efforts depends on contributions from a number of scientific, engineering, and cechnical support personnel. Those members of the LLN Synroc project team whose efforts made this report possible include:

Program Managers:

Ceramic Processing:

Leaching Studies:

Product Characterization:

Analytical Chemistry:

Physical Property Measurements:

Clerical :
Jack Campbel 1 and John Tewhey.

Herb Newkirk, Conrad Yu, Carolyn Rossington, Bill Wade, Kalph Smith, Ken Deas, and Gene Hammeral .

Susan MacLean and Art Langhorst. Gordon Smith, Rick Ryerson, Charles Farrell, Al Ulricht, Chuck Slottevold, Carol Weaver, and Roy Lindahl.

Bob Lim, Bill Sunderland, and Richard Ryon.

A. E. Brown, D. Hiromato, R. C. Lum, R. L. Brady, W. L. Thaver, R. S. Grady, and M. Karch .

Robin McClure and Cindy Anderson. 
PREPARATION AND PROPERTIES OF SYNROC D CONTAINING

SIMULATED SAVANNAH RIVER PLANT HIGH-LEVEL DEFENSE WASTE

\section{ABSTRACT}

We describe in detail the formulation and processing steps used to prepare all Synroc $D$ samples tested in the Comparative Leach Testing Program at the Savannah River Laboratory. We also discuss how the composition of the Savannah River Plant sludge influences the formulation and ultimate preparation of Synce D. Mechanical properties are reported in the categories of elastic constants, flexiral and compressive strengths, and microhardness; thermal expansion and thermal conductivity results are presented. The thermal expansion data indicated the presence of significant residual strain and the possibility of an unidentified amorphous or glassy phase in the microstructure. We summarize the standardized (MCC) leaching results for both crushed Synrec and monoliths in deionized water, silicate water, and salt brine at $90^{\circ} \mathrm{C}$ and $150^{\circ} \mathrm{C}$.

\section{INTRODUCTION}

Defense wastes represent most of the high-level nuclear waste in the United States. 1 These wastes are presently stored in three DOE facilities: the Savannah River Plant near Aiken, SC, the Hanford Plant near Hanford, WA, and the Idaho Chemical Processing Plant near Idaho Falls, ID. A total of about $2.8 \times 10^{5} \mathrm{~m}^{3}$ (75 million gallons) of waste containing about $1.3 \times 10^{9} \mathrm{Ci}$ has been generated as - result of producing plutonium and tritium for nuclear veapons. By 1990, the project ad inventory of defense waste is expected to reach $1.8 \times 10^{9} \mathrm{Ci}$--an increase of about 387 .

In comparison, commercial wastes in the United States (mostly in the form of unprocessed spent reactor-fuel elements) represent a slightly larger inventory of about $5 \times 10^{9} \mathrm{Ci}$. By 1990 , this commercial inventory is expected to reach $23 \times 10^{9} \mathrm{Ci}--a n$ increase of about $360 \mathrm{z}$.

The Mineral Waste Form Program at the Lawrence Livermore National Laboratory (LLML) was established to develop techniques to imobilize 
radioactive wastes at the Savannah River Plant (SRP), which has operated since 1953. These acid wastes have been neutralized with sodium hydroxide and are presently stored in large underground tanks as precipitated sludge, alkaline salt cake, and supernate.

In 1977, the Energy Research and Development Administration (now Department of Energy) completed a site-specific study for SRP as a step toward establishing long-range goals and policies to insure safe permanent disposal of these wastes. Twenty-three separate plans for the processing and storage of SRP wastes were evaluated in this study. ${ }^{2}$ At that time, the only solid waste forms under consideration were glasses, concrete, dry sludge, and salt cake. Borosilicate glass was eventually selected as the reference form for waste imobilization. Subsequent additional studies were also initiated on 11 solid waste forms as alternates to glass. ${ }^{3}$ This became known as the Alternate Waste Form Program. As a part of this program, LLNL was designated the lead laboratory to evaluate the synroc ${ }^{4}$ concept and its potential to inmobilize SRP waste. An important part of the evaluation process was the Comparative Leach Testing Program (CLT) in which all participants supplied waste-form samples to the SRP for evaluation using standardized leach tests.

This report summarizes the method we used to prepare the Synroc D samples submitted for CLT and presents the results of thermal- and mechanical-property tests we made on these samples.

\section{DESCRIPTION OF SAVANNAH RIVER PLANT WASTE}

The 1980 inventory ${ }^{1}$ of stored SRP waste was $1 \times 10^{5} \mathrm{~m}^{3}$ (25 million gallons) of sludge, alkaline salt cake, and supernate. About $85 \%$ of this waste is supernate/salt that contains most of the radioactive cesium and some of the strontium. The balance, about $15 \%$, is sludge, an alkaline mixture of hydrous oxides produced by neutralizing acid wastes with excess $\mathrm{NaOH}$ (Fig. 1). Because about $95 \%$ of the soluble salts can be removed from the sludge by washing, 5,6 each cubic metre of waste yields $180 \mathrm{~kg}$ (i.e., $1.5 \mathrm{Ib} / \mathrm{gal}$ ) of washed and dried sludge. Hence, the total approximate dried solid-waste equivalent in the 1980 inventory was 2,550 metric tons. With a processing throughput goal of one ton/day, it would take from seven to eight years to convert all present SRP waste into a waste form suitable for storage. 

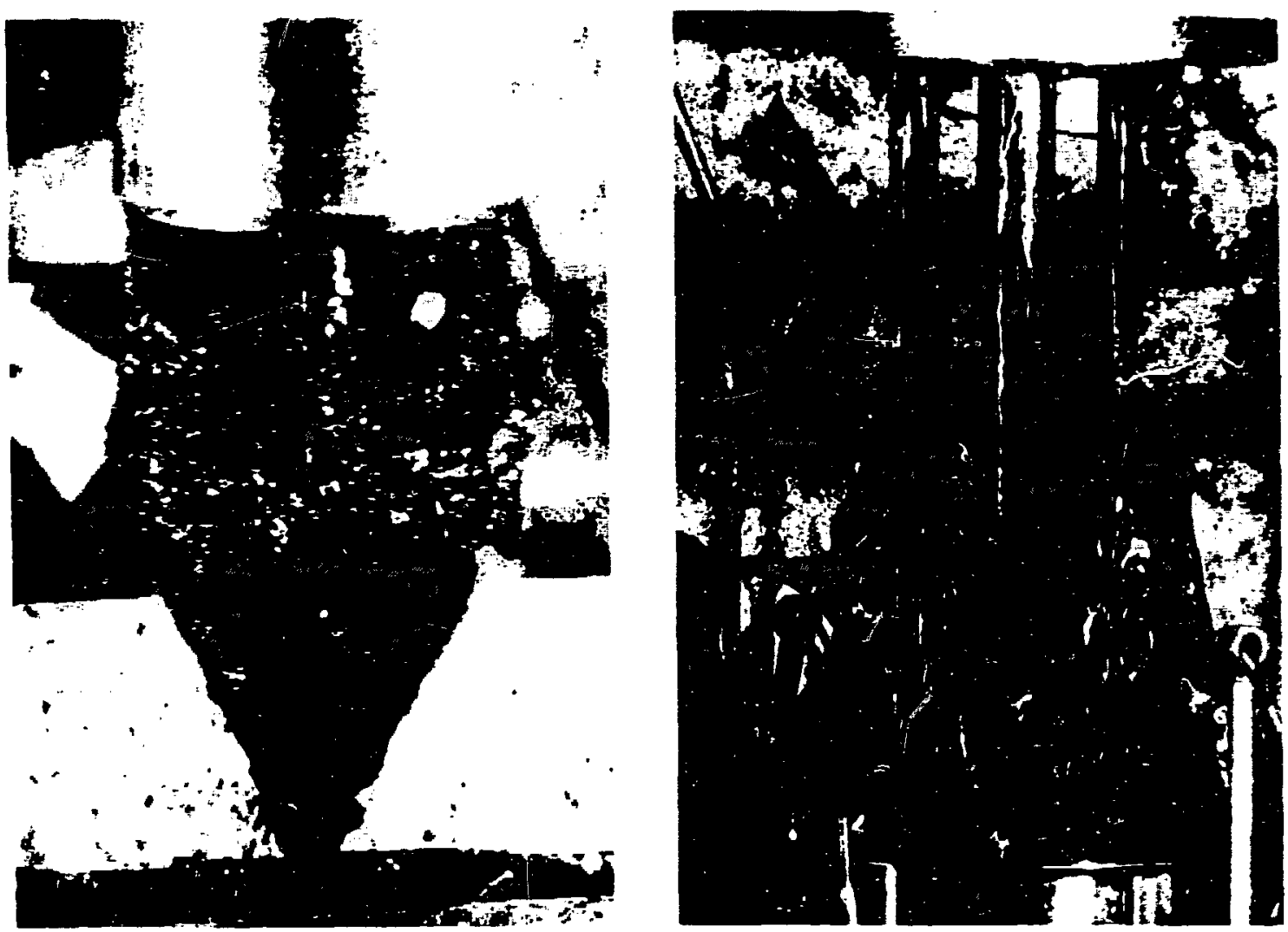

Figure 1. High-level radioactive sludge stored at the Savannah River Plant in (a) Tank No. 7 and (b) Tank No. 15. The sludge, which represents about $15 \%$ of the radioactive waste at SRP, is an alkaline mixture of hydrous oxides produced by neutralizing acid wastes with excess $\mathrm{NaOH}$.

Detailed descriptions of the radionuclide content ${ }^{2}$ and the processing steps $^{3}$ for the reference glass waste form may be found in earlier reports.

The 1980 reference-glass process consists of three input feed streams:

1. The major feed stream is a slurry of washed sludge containing hydrous oxides of elements such as iron, aluminum and manganese. Washing removes about $95 \%$ of the soluble salts, and the sludge contains most of the radionuclides in the waste, including ${ }^{90} \mathrm{Sr},{ }^{239} \mathrm{Pu}$, and rare-earth fission products. About $75 \%$ of the aluminum is removed by caustic washing; this step is desirable for the reference borosilicate glass process but is not required for the Synroc waste form.

2. The second feed stream is a slurry of aluminosilicate zeolite grains (ion exchange column) containing ${ }^{137} \mathrm{Cs}$ adsorbed from the supernate fraction 
of SRP waste. The volume and mass of this stream is relatively small, but it contains nearly all of the ${ }^{137} \mathrm{Cs}$ radionuclide.

3. The third stream, also minor, contains dissolved Na-EDTA, tine eluting agent for ion-exchange separation of ${ }^{90} \mathrm{Sr}$ from the supernate fraction of SRP waste. This stream, labelled "Sr concentrate," contains only a smail part of total ${ }^{90} \mathrm{Sr}$.

The reference-glass process is continously evolving; coneequently, some of these feed streams may change in the future. Table 1 lists the average major-element compositions of the waste stream, given as oxide/salt equivalents. Compositions with and without aluminum are also given because aluminum removal by caustic washing was an added step required by the reference borosilicate glass process. Contractors studying the alternate waste forms were allowed to choose compositions from either category in order to optimize their waste-form performance for CLT; we chose the composition from which aluminum had not been removed.

In Table 1, each category consists of three compositions: high iron, $h i$ ph aluminum, and composite. The high-iron and high-aluminum compositions are thought to represent the compositional extremes whereas the "composite"

Table 1. Compositions of SRP waste calcines. ${ }^{a, b}$

Without aluminum removal (wt\%)

Component

High Fe Composite High Al

$$
53.17
$$

4.89

$\mathrm{Al}_{2} \mathrm{O}_{3}$

$\mathrm{MnO}_{2}$

$\mathrm{U}_{3} \mathbf{0}_{8}$

$\mathrm{CaO}$

NiO

$\mathrm{SiO}_{2}$

$\mathrm{Na}_{2} \mathrm{O}$

$\mathrm{Na}_{2} \mathrm{SO}_{4}$

Zeolite
3.56

12.34

3.62

9.08

0.40

4.52

$<0.50$

8.82

100.90

$$
36.13
$$

28.26

9.94

3.26

2.69

4.47

0.85

5.08

0.93

8.93

100.54

\subsection{2}

76.05

4.37

1.28

0.35

0.78

0.56

1.96

$<0.50$

9.33

100.50

With aluminum removal ( $\left(\omega t_{\circ}^{\circ}\right)$

High Fe Composite High Al

55.99

1.29

3.74

12.98

3.80

9.54

$<0.40$

4.75

$<0.50$

8.00

100.90
47.16

9.24

12.98

4.25

3.51

5.84

1.12

6.63

1.21

B.05

99.99
14.80

50.77

12.16

3.57

0.97

2.17

1.57

5.41

$<0.50$

8.53

100.50

a Values taken from Ref. 2.

b Only the major elements are 1 isted.

c Ion-Siv IE-95; mixture of $\mathrm{CaAl}_{2} \mathrm{Si}_{4} \mathrm{O}_{12} \cdot 6 \mathrm{H}_{2} \mathrm{O}$ and $(\mathrm{NaKCa})_{3} \mathrm{Al}_{3} \mathrm{SiO}_{24} \cdot 8 \mathrm{H}_{2} \mathrm{O}$. 
composition represents an average of the total tank inventory at SR?. During processing, extensive blending of the SRP waste is planned, which will give greater importance to the composite compositions. However, because significant variations in tank feed are possible, the waste form must also be able to accomnodate the extreme high-iron and high-aluminum compositions.

The glass reference process calls for an aluminosilicate ion-exchange media (zeolite) to separate cesium from the salt/supernate. Other ion-exchange media such as titanates, which are more compatible with the Synroc process, are also acceptable as a substitute for zeolite.

Uranium oxide $\left(\mathrm{U}_{3} \mathrm{O}_{8}\right)$ is the only radioactive compound listed in Table 1. The total fraction of other radionuclides constitutes about $3 \%$ of the calcinated SRP waste. Table 2 lists weight-percent ranges for 37 minor elements that have also been identified. Some of these elements (such as $C$, $\mathrm{Cl}, \mathrm{Hg}, \mathrm{P}, \mathrm{Pb}, \mathrm{Ag}$, and $\mathrm{F}$ ) may affect both waste-form synthesis and performance, but in this initial development program, these elements were not included in the waste formulation. Simulated waste supplied to us by SRP

Table 2. Minor elements in SRP waste sludges. ${ }^{a, b}$

\begin{tabular}{|c|c|c|c|}
\hline Element & Range (wt\%) & Element & Range (wt\%) \\
\hline $\mathrm{Ag}$ & $0-0.3$ & $\mathrm{Nb}$ & $0.02-01$ \\
\hline B & $0-0.05$ & Nd & $0.3-1.0$ \\
\hline $\mathbf{B a}$ & $0.1-0.25$ & $\mathbf{P}$ & $0.03-0.3$ \\
\hline $\mathrm{C}$ & $0-16.8$ & $\mathrm{~Pb}$ & $0.1-0.5$ \\
\hline $\mathrm{Cd}$ & $0-0.05$ & Pd & $0-0.03$ \\
\hline $\mathrm{Ce}$ & $0.05-1.0$ & $\mathrm{Pm}$ & $0-0.04$ \\
\hline $\mathrm{Cl}$ & $0-2.0$ & $\mathbf{P r}$ & $0.04-0.2$ \\
\hline Co & $0-0.01$ & $\mathbf{R h}$ & $0-0.05$ \\
\hline $\mathrm{Cr}$ & $0.01-0.45$ & $\mathbf{R u}$ & $0.03-0.5$ \\
\hline Cs & $0-0.06$ & $\mathbf{S}$ & $0.02-0.5$ \\
\hline $\mathrm{Cu}$ & $0.03-0.15$ & Sta & $0-0.05$ \\
\hline Eu & $0-0.02$ & $\mathbf{S r}$ & $0-0.15$ \\
\hline $\mathbf{F}$ & $0-0.15$ & Th & $0-0.18$ \\
\hline $\mathrm{Hg}$ & $0.1-2.8$ & $\mathrm{Ti}$ & $0-0.1$ \\
\hline $\mathrm{K}$ & $0.02-0.14$ & $\mathbf{v}$ & $0-0.01$ \\
\hline La & $0.04-0.3$ & $\mathbf{Y}$ & $0.01-0.05$ \\
\hline $\mathrm{Mg}$ & $0.06-0.3$ & $\mathrm{Zn}$ & $0.04-0.5$ \\
\hline Mo & $0-0.01$ & $\mathbf{Z r}$ & $0.1-0.5$ \\
\hline
\end{tabular}

¿̀ Values taken from Ref. 2 .

b Value is wt\% in washed, dried sludges. 
contained only uranium, strontium, neodymium, and cerium as radwaste elements; we added enough cesium to make its concentration equal to that of strontiur.

The concentration of sodium in SRP sludge is about $5 \%$ (see Table 1). Sodium concentrations are of concern because Synroc minerals have a limited capacity to accommodate sodium. As will be shown, we immobilize sodium in a silicate phase (nepheline). This phase has much poorer leach resistance than the normal titanate Synroc phases. Also, the large amount of sodium and the silica additive used to make nepheline increase the chance for formation of amorphous phases in our ceramic waste form.

\section{THE COMPARATIVE LEACH. TESTING PROGRAM}

The CLT program ${ }^{7}$ was initiated by SRI to provide the performance information needed to select one alternate waste form (in addition to borosilicate glass) for further development in FY 82-83. The program was designed to provide test data by August 1981, when the alternate vaste form would be selected for further hot-cell testing and engineering studies.

All waste-form developers were asked to provide input to SRL before the plan was finalized. The LLNL response ${ }^{8}$ dealt with our concerns about leaching temperatures, neutron activation of test samples before leaching, emphasis on composite, high-iron, and high-aluminum compositions, leach solutions that simulate geochemical conditions, and surface-preparation procedures.

Once the final CLT plan was adopted, ${ }^{9}$ SRL sent the plan and three specially prepared sludge compositions (composite, high iron, and high aluminum) to the waste-form developers. Each sludge contained a mixture of strontium, cerium, neodymium, and uranium to simula e fission products and actinides in the waste. Each develcper was allowed to add cesium from the supernate in any form desired with the proviso that the concentration ci cesium and strontium be equivalent and that the method of addition be based on the actual plant process. The plan included a detailed description of the methods used to prepare these simulated SRP sludges (Appendix A).

The plan also included instructions and guidelines on sample preparation and leach testing. It required that final waste-form samples for testiug be in the fcrm of large pieces or fragments that could be core-drilled or sawed into mo:koliths for leach testing. 
Both the SRL developers of the reference glass and six off-site waste-form developers submitted samples incorporating the three simulated compositions. These seven waste forms were:

- Borosilicate glass, from the DWPF reference process (SRL) 10

- High-silica glass, from a porous glass matrix process (CUA). 11

- Tailored ceramic derived from the supercalcine concept (RES). 12

- Synroc, a titanate-based ceramic (LLNL).13

- Coated ceramic pellets (PNL). 14

- Coated sol-gel spheres (ORNL).15

- FUETAP (Formed Under Elevated Temperature And Pressures) concrete (ORNL). 16

These six waste forms were tested and evaluated at SRL. Leaching tests using neutron activation at SRL were complemented with off-site leach testing by the Materials Characterization Center (MCC) and by the waste-form developers. CLT samples were tested using the standardized Materials Characterization Center (MCC) tests. 17,18 Furthermore, in the case of Synroc, we at LLRL characterized the microstructure, mineralogy, radwaste distribution among the various phases, mechanical and thermophysical properties of our waste form. We also evaluated the probable effects of radiation damage. 19

In preparing our Synroc D samples for the CLT program, we intensively studied surrogate waste cimpositions to establish the correct additives and processing conditions. Most of our work was devoted to the SRP composite waste composition. Three spray-dried composite compositions ( $507, \mathrm{~s} 10$, and S11) were needed to optimize the final conditions necessary before the samples were prepared for CLT. In the case of the compositional extremes in SRP wastes, two spray-dried compositions [S12 (high iron) and S14 (high aluminum)] were evaluated before the CLT samples were prepared

During October and November 1980, SRL shipped about $2 \mathrm{~kg}$ of simulated composite sludge (air dried and hydrated) and about $1.3 \mathrm{~kg}$ of both "high iron" and "high aluminum" to LLNL. These sludges were analyzed at LLNL and the composition compared wich the "as-made" values reported by SRL (Appendix A).

We sent our first Synroc composite CLT waste form [with cesium added as a hollandite solid solution--(S21-S18)] to SRL in January 1981. The high-iron waste form with cesi:m added as a hollandite solid solution (S26-SAN) was shipped in April 1981. The high-aluminum waste form with cesium mineralized in situ as nepheline or pollucite was shipped in June 1981. 
At the request of $S R L$, we sent two additional waste-form samples to $S R L$ during this period. These two samples were not prepared using SRL simulated waste because we had insufficient SRL material. Instead, we prepared a nearly identical substitute by adding the radwaste components strontium, cesium, cerium, neodymium, and uranium to simulated sludges prepared by Southwestern Analytical Chemicals,. Inc. (Austin, TX). The major oxide components were similar to the simulated waste supplied by SRL. Compositions were again confirmed by analyses at LLNL.

Our first alternate sample (S29) was a composite sample with cesium mineralized in situ as nepheline (or possibly pollucite); it was shipped in May 1981. Preparation of this sample involved a different processing concept. In making the first sample (s21-s18), cesium had been mineralized first as a hollandite solid solution and then added to the bulk waste. (If this concept is adopted, cesium will be processed separately from the sludge stream but using the same equipment. This approach may have merit for the two-stage processing schedule now envisioned for SRP waste.) In preparing sample S29, however, cesium was added to the sludge stream as a water-soluble salt and mineralized in situ in nepheline (or pollucite).

Our second alternate sample (S30-HP3A) was a high-iron sample; it was shipped in June 1981. We submitted this sample because our first sample (S26-SAN) exhibited cracking. We determined that the high-magnetite phase component in this waste form was highly susceptible to localized nonisothermal heating effects when the sample was inductively hot pressed. These effects could be eliminated entirely by resistive hot pressing, and we submitted sample S30-HP3A as a replacement for the high-iron sample. Also, the resistively hot pressed sample more closely represents the reference Synco: process in which hot isostatic pressing (HIP) is used for densification.

\section{SYNROC D FORMULATIONS}

\section{GENERAL BACKGROUND}

Exploratory phase-equilibria studies by Ringwood ${ }^{4}$ showed that adding $\mathrm{TiO}_{2}, \mathrm{ZrO}_{2}, \mathrm{CaO}$, and $\mathrm{SiO}_{2}$ to the three SRP simulated waste compositions yielded three radwaste host phases: zirconolite $\left(\mathrm{CaZrT}_{2} \mathrm{O}_{7}\right.$ ), perovskite $\left(\mathrm{CaTiO}_{3}\right)$, and nepheline $\left(\mathrm{NaAlSi}_{2} \mathrm{O}_{6}\right)$. The remaining phases, which did 
not act as radwaste hosts, were iron-aluminum spinel-solid solutions $\left(\mathrm{MO} \cdot \mathrm{M}_{2} \mathrm{O}_{3}\right)$ of varying compositions. Ringwood made hot pressings of small samples at $0.5 \mathrm{GPa}(73 \mathrm{ks})$ at temperatures between 1000 and $1300^{\circ} \mathrm{C}$ and at differenc oxygen fugacities using platinum, iron, and nickel capsules. For all compositions, the solidus temperatures were in the range of 1150 to $1200^{\circ} \mathrm{C}$. Only those samples hot pressed at or above $1150^{\circ} \mathrm{C}$ had crystallite sizes sufficiently large to allow accurate phase cnnpositions to be determined using the electron microprobe. Ringwood reported difficulty in achieving phase equilibrium in his mixed oxide samples at temperatures below $1100^{\circ} \mathrm{C}$.

Table 3 summarizes phase compositions determined by Ringwood for the three SRP compositions. In this study, Ringwood reported the partitioning behavior of only two radwastes (uranium and samarium). Uranium, reported as $\mathrm{UO}_{2}$, partitioned predominantly into zirconolite regardless of the sludge composition. The concentrations of $\mathrm{UO}_{2}$ in zirconolite were in the range of 4 to $5.5 \mathrm{~mol} \%$. Smaller amounts of $\mathrm{UO}_{2}(0.7$ to $1.3 \mathrm{~mol} \%)$ also partitioned into perovskite. Ringwood made the general observation that uranium and other tetravalent actinides partition in zirconolites and perovskites in ratios (zir/per) varying from 2 to 5, depending on the early mineralization history and oxygen fugacity. Ringwood suggested that if time-temperature conditions are favorable to early perovskite formation, then subsequent redistribution of uranium into zirconolite may be more difficult.

The only data for rare-earth particioning reported by Ringwood was for the composite sludge. Table 3 shows that $\mathrm{Sm}_{2} \mathrm{O}_{3}$ partitioned into both zirconolite $(0.7 \mathrm{~mol} \%)$ and perovskite $(1.5 \mathrm{~mol} \%)$ in the ratio of 0.5 (zir/per). Ringwood described similar partitioning behavior for other rare earths and also postulated that $\mathrm{Am}^{+3}$ and $\mathrm{Pu}^{+3}$ would partition in this manner.

Ringwood gave no data for sesium and strontium in his report. However, on the basis of his work with Synroc, he be:lieved that strontium and cesium would partition strongly into perovskite and nepheline, respectively. Ringwood indicated his general preference for hollandite orer nepheline as a cesium waste form except when sodium levels in the sludge were high.

Another feature of Ringwood's data (Table 3) is the importance of the iron oxidation state in iron oxide. Depending on the siudge composition, the iron oxidation state is important in controlling the spinel mineralogy and composition if the amount of titania $\left(\mathrm{TiO}_{2}\right)$ consumed in spinel formation is to be minimized. When the sludge contains sufficient alumina to react 
Table 3. Phase compositions of Synroc D containing simulated SkP sludges from Ringwood. ${ }^{a}$

Est imated amount of phase in vaste composition (vtz)

Phase Composite ${ }^{b}$

High iron ${ }^{c}$

High a! ininum

\begin{tabular}{llll}
\hline Zirconolite & 16 & 15 & 16 \\
Perovskite & 11 & 11 & 13 \\
Nepheline & 18 & 15 & 16 \\
Spinel & 55 & 59 & 55 \\
\hline
\end{tabular}

Oxide content of phase in each waste composition (mol\%)

Zirconolite

Oxidè

Perovskice

Nephel ine

Al
Comp. $\mathrm{Fe}$

Al
Spine1

Comp. Fe

A 1

\begin{tabular}{|c|c|c|c|c|c|c|c|c|c|c|c|c|}
\hline $\mathrm{TiO}_{2}$ & 40.6 & 42.1 & 35.8 & 49.9 & 46.0 & 47.1 & 0.4 & 0.4 & 0.2 & 15.7 & 10.0 & 6.2 \\
\hline $\mathrm{ZrO}_{2}$ & 26.5 & 19.7 & 29.6 & $<0.1$ & 0.8 & 0.4 & - & - & - & 0.2 & - & 0.2 \\
\hline $\mathrm{CaO}$ & 17.5 & 25.0 & 21.2 & 45.3 & 49.8 & 48.0 & 1.0 & - & - & 0.4 & - & - \\
\hline $\mathrm{uO}_{2}$ & 4.1 & 5.5 & 5.0 & $<0.8$ & 0.7 & 1.3 & - & - & - & $<0.03$ & - & - \\
\hline $\mathrm{Sm}_{2} \mathrm{O}_{3}$ & 0.7 & - & - & 1.5 & - & - & - & - & - & - & - & - \\
\hline $\mathrm{Na}_{2} \mathrm{O}$ & 1.1 & 0.3 & 3.6 & $<0.6$ & - & - & 24.7 & 23.6 & 24.7 & $<0.14$ & - & - \\
\hline $\mathrm{SiO}_{2}$ & - & - & - & - & - & - & 48.7 & 49.2 & 49.1 & - & - & - \\
\hline $\mathrm{Al}_{2} \mathrm{O}_{3}$ & 1.0 & 0.4 & 1.0 & 0.1 & 1.1 & 0.2 & 24.7 & 24.6 & 25.0 & 14.8 & 7.9 & 40.3 \\
\hline $\mathrm{Fe}_{2} \mathrm{O}_{3}$ & 4.4 & 4.7 & - & 1.3 & 0.7 & - & 0.5 & 2.3 & - & 11.2 & 28.9 & - \\
\hline $\mathrm{FeO}$ & - & - & 5.5 & - & - & 2.3 & - & - & 0.8 & 37.8 & 27.3 & 44.4 \\
\hline MnO & 1.3 & 2.4 & 1.2 & 0.3 & 0.8 & 0.7 & - & - & 0.2 & 13.3 & 12.8 & 8.7 \\
\hline NiO & 2.8 & - & - & 0.2 & 0.2 & - & - & - & - & 6.7 & 13.1 & 0.4 \\
\hline Totals & 100.0 & 100.1 & 99.9 & 100.1 & 100.1 & 100.0 & 100.0 & 100.1 & 200.0 & 100.3 & 100.0 & 100.2 \\
\hline
\end{tabular}

a Ref. 4 .

b Composite sludge was hot pressed in a nickel capsule at $5 \mathrm{kbar}$ and $1150^{\circ} \mathrm{C}$ for $1 \mathrm{~h}$; doped with $1-2 \% \mathrm{Sm}_{2} \mathrm{O}_{3}$.

c High-iron sludge was hot pressed in a platinum capsule at $5 \mathrm{kbar}$ and $1150^{\circ} \mathrm{C}$ for $1 \mathrm{~h}$.

d High-aluminum sludge was hot pressed in an iron capsule at $5 \mathrm{kbat}$ and $1200^{\circ} \mathrm{C}$ for l h. 
Table 4. Nominal composition for Synroc D simulated composite oludges (S11, S2 1 and S29).

Chemical

ingredient
S11

$(w t z)$
529

$(w t z)$
S21

(wtz)
Average sludge

composition (utz)a

\section{Composite sludge}

$\begin{array}{lrrrc}\mathrm{Fe}_{2} \mathrm{O}_{3} & 26.2 & 23.8 & 24.7 & 27.1 \\ \mathrm{Al}_{2} \mathrm{O}_{3} & 20.4 & 18.6 & 19.3 & 21.2 \\ \mathrm{MnO}_{2} & 8.1 & 7.4 & 6.0 & 6.1 \text { (Ano) } \\ \mathrm{CaO} & 1.4 & 1.8 & 1.7 & 2.0 \\ \mathrm{NiO} & 3.3 & 3.0 & 3.2 & 3.4 \\ \mathrm{Na}_{2} \mathrm{O} & 3.6 & 3.3 & 2.8 & 3.8 \\ \mathrm{Na}_{2} \mathrm{SO}_{4} & 0.6 & 0.6 & 1.4 & 0 \\ \mathrm{SiO}_{2} & 0.6 & 0.6 & 0.5 & 0.6 \\ & \frac{0.6}{64.2} & 59.1 & 59.6 & 6 . \overline{2}\end{array}$

Radioactive waste compounds

$\begin{array}{lllll}\mathrm{U}_{3} \mathrm{O}_{8} & 2.4 & 2.1 & 2.3 & 2.3 \\ \mathrm{Cs}_{2} \mathrm{O} & 0 & 0.25 & 0 & 0 \\ \mathrm{SrO}^{\mathrm{Ce}} & 0.4 & 0.25 & 0.26 & 0 \\ \mathrm{Ce}_{2} \mathrm{O}_{3} & 0.4 & 0.50 & 0.54 & 1-2 \mathrm{Z} \mathrm{Sm}_{2} \mathrm{O}_{3} \\ \mathrm{Gd}_{2} \mathrm{O}_{3} & 0.4 & 0 & 0 & 0 \\ \mathrm{Nd}_{2} \mathrm{O}_{3} & 0.4 & 0.50 & 0.54 & 0 \\ \mathrm{Eu}_{2} \mathrm{O}_{3} & 0.4 & \frac{0}{3.6} & \frac{0}{3.6} & \frac{0}{4.3}\end{array}$

$\frac{\text { Synroc additives }}{\mathrm{CaO}}$

$\mathrm{ZrO}_{2}$

$\mathrm{TiO}_{2}$

$\mathrm{SiO}_{2}$

Totals

\section{7}

5.3

15.4

$\frac{7.0}{31.4}$

$\overline{100.0}$

\section{3}

6.5

18.8

$\frac{6.6}{37.3}$

$\overline{100.0}$
5.4

6.2

18.4

$\frac{6.7}{36.7}$

$\overline{99.9}$
4.9

4.0

15.0

$\frac{7.5}{31.4}$

$\overline{100.0}$

a From Ringwood, Ref. 4.

completely with iron oxide (to form a hercynite-type spinel, $\mathrm{FeAl}_{2} \mathrm{O}_{4}$ ), then redox conditions near the Fe/FeO buffer were employed to reduce all iron oxide to FeO. These conditions exist in the case of the high-aluminum sludge, and the iron oxide component for this sludge is reported as Feo (Table 3). In the case of higi-icon sludges, ess powerful reducing conditions at the $\mathrm{Ni} / \mathrm{NiO}$ buffer are needed to form magnetite $\left(\mathrm{Fe}_{3} \mathrm{O}_{4}\right)$. Ringwood described the composite-sludge spinel as a complex solid solution between the ferrite and 
hercynite spinels. For the high-iron and compusite spinels shown in Table 3 , the $\mathrm{FeO} / \mathrm{Fe}_{2} \mathrm{O}_{3}$ mol ratios were 1.0 and 3.4 , respectively.

The composite waste forms that we hot pressed at $1050^{\circ} \mathrm{C}$ contained two spinels instead of one. One spinel was $r i c h$ in hercynite whereas the other was rich in ulvospinel $\left(\mathrm{Fe}_{2} \mathrm{TiO}_{4}\right)$ and magnetite. The high-aluminum and high-iron waste forms prepared at LLKL showed sing:e-spinel formation. A detailed discussion of the phase equilibria responsible for our double-spinel waste form was given previously. ${ }^{20}$ Basically, we believe that the two spinels formed early at the $800^{\circ} \mathrm{C}$ calcination step and that subsequent hot pressing to $1050^{\circ} \mathrm{C}$ for $1 \mathrm{~h}$ was insufficient to completely equilibrate the waste form into a single-phase spinel.

In our formulations of Synroc D for CLT samples, we relied on Ringwood's work $^{4}$ (Table 3), especially in the case of spinel compositions and uranium-rare earth partitioning. However, we extended his work with our own syntheses and phase analyses for composite waste forms ( 511 and 521 ) containing $\mathrm{yO}_{2}, \mathrm{SrO}$, and rare earth oxides. Table 4 shows the nominal composition for S1l, S21, S29, and Ringwood's composite sludge. The nominal compositions of all synroc D samples sent to SRL for testing are 1 isted in Append ix B.

We prepared samples $S 11$ and $S 21$ to study their phase characteristics. The components were first siurry-mixed and then spray dried to a power that was calcined in air to constant weight.

To make S11, titanium powder was added directly to air-calcined powder to allow in situ redox control during hot pressing. The amount of titanium added was calculated to ad just the mol ratio of $\mathrm{FeO} / \mathrm{Fe}_{2} \mathrm{O}_{3}$ to about 3.4 , similar to that reported by Ringwood in Table 3 . During hot pressing in a nickel capsule, the sample (S11-HP3A) was first held at $800^{\circ} \mathrm{C}$ (a temperature just below the onset of densification) for 60 min to allow redox equilibration. The sample was then heated to $1100^{\circ} \mathrm{C}$ and held for 50 min at $27.6 \mathrm{MPa}$ (4 ksi). During this period, the temperature fluctuated between 1070 and $1140^{\circ} \mathrm{C}$ as a result of power-control problems. Because we observed large grain growth in the microstructure, we believe that the sample may have reached the solidus temperature momentarily during this period (Fig- 2a).

To make S21, the air-calcined powder was then calcined in a reducing gas environment of flowing $\mathrm{Co} / \mathrm{CO}_{2}$. In this case, titanium additions were unnecessary. The sample S21-HP3A was hot pressed above the solidus 

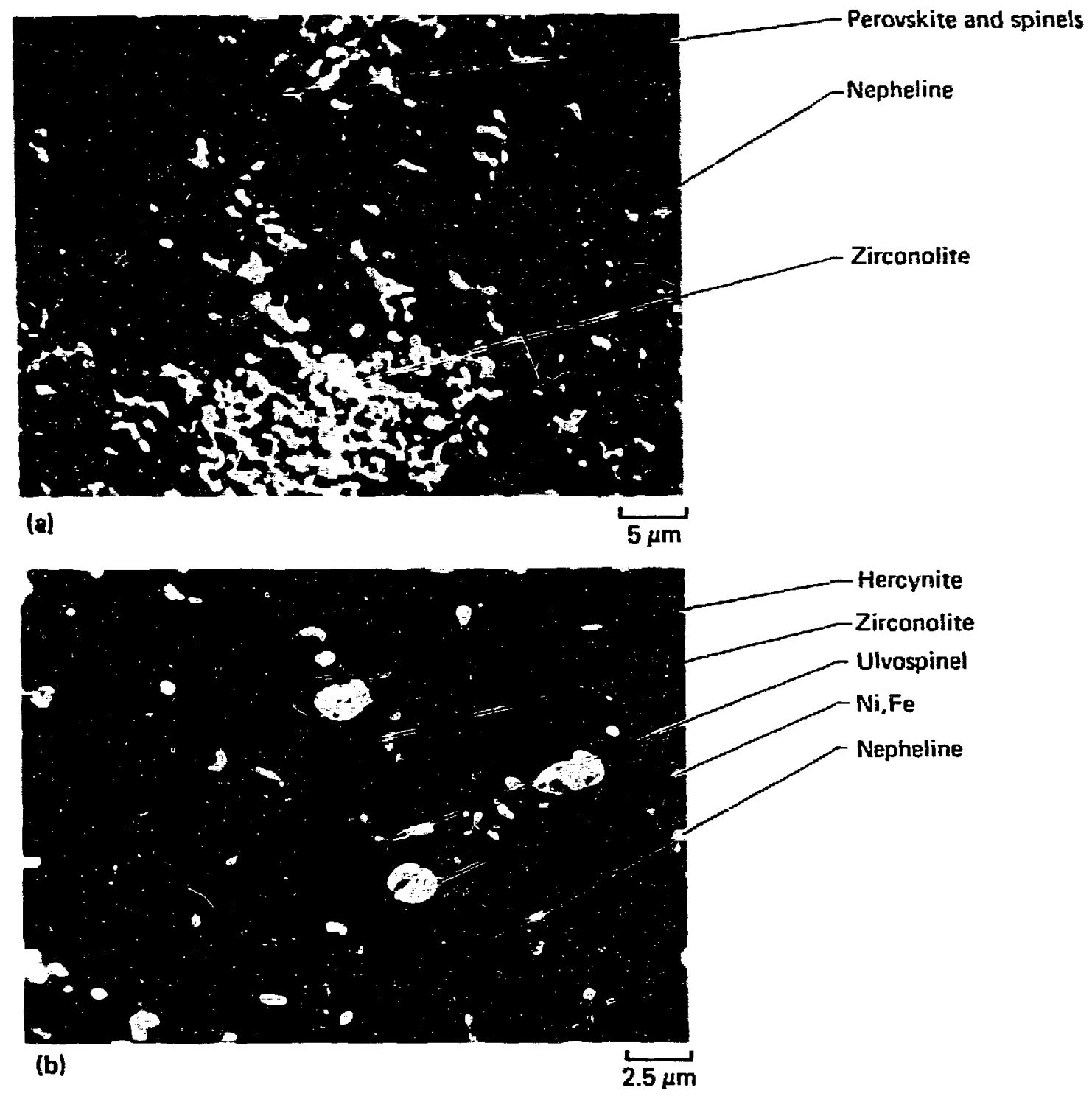

Figure 2. Scanning electron micrascope photographs of composite Synroc D samples. (a) Sample Sll-HP3A after hot pressing in a nickel capsule to $1100^{\circ} \mathrm{C}$ at $27.6 \mathrm{MPa}$ (4 ksi) for $50 \mathrm{~min}$. (b) Sample s2l-HP3A after hot pressing in graphite to $1200^{\circ} \mathrm{C}$ at $6.9 \mathrm{MPa}$ ( $1 \mathrm{ksi}$ ) for $30 \mathrm{~min}$.

temperature at $1200^{\circ} \mathrm{C}$ to promote large grain growth for the purpose of microstructural analysis (Fig. $2 b$ ).

Table 5 lists the electron-microprobe phase characterizations for $\mathbf{S l l}$ and S21. A more detailed and inclusive phase- anc microstructural-characterization study of Synroc $D$ was made by Ryerson and Smith. 21 A comparison of the 
Table 5. Microprobe analyses of perovskite, zirconolite and spinel phases in two composite Synroc D samples.

\section{Composition (molz)}

\begin{tabular}{|c|c|c|c|c|c|}
\hline Zirco & olite & Pero: & skite & & \\
\hline S11-HP3A & S21-HP 1A & S11-HP3A & S21-HP IA & & \\
\hline & & & & No. 1 & No. 2 \\
\hline 36.0 & 39.4 & 50.3 & 49.8 & 20.9 & 6.8 \\
\hline 22.1 & 14.8 & 0.5 & 0.3 & 0 & 0 \\
\hline 16.4 & 25.6 & 35.9 & 37.1 & 0 & 0 \\
\hline 0.8 & 0.1 & 0.8 & 1.1 & 1.4 & 1.4 \\
\hline 2.8 & 2.5 & 1.1 & 3.2 & 12.0 & 9.4 \\
\hline 7.6 & 5.2 & 3.7 & 3.1 & 46.5 & 39.2 \\
\hline 3.7 & 4.4 & 1.2 & 1.7 & 19.3 & 43.3 \\
\hline 5.9 & 3.9 & 0.1 & 0 & 0 & 0 \\
\hline 0.8 & 0.2 & 3.1 & 0.5 & 0 & 0 \\
\hline 3.5 & 2.7 & 0.5 & 1.3 & 0 & 0 \\
\hline c & $0.8^{d}$ & $0.3^{d}$ & $0.1^{\mathrm{d}}$ & 0 & 0 \\
\hline 0.1 & 0.4 & 1.2 & 1.7 & 0 & 0 \\
\hline 0.3 & e & 1.2 & e & e & e \\
\hline e & f & $e$ & $\mathbf{f}$ & $\mathbf{E}$ & $\mathbf{f}$ \\
\hline e & $\underline{f}$ & e & $\mathbf{f}$ & $f$ & $\mathbf{f}$ \\
\hline 99.9 & 100.0 & 100.0 & 99.9 & 99.9 & 100.0 \\
\hline
\end{tabular}

a LLNL analyses by $R$. Ryerson.

b SIl-HP3A was hot pressed in a nickel capsule at $4 \mathrm{ksi}$ and $1100^{\circ} \mathrm{C}$ for $1 \mathrm{~h}$. S21-HP lA was hot pressed in graphite at $1 \mathrm{ksi}$ and $1200^{\circ} \mathrm{C}$ for $0.5 \mathrm{~h}$.

c Below detection limit.

d Estimates.

Not analyzed.

f Not added.

phase compositions for major constituents in $S 11$ and $S 21$ with those reported by Ringwcod ${ }^{4}$ ( $T a b l e ~ 3$ ) showed good agreement for $\mathrm{TiO}_{2}$ and $\mathrm{ZrO}_{2}$ in percuskite and zirconolite. The agreement for CaO was only fair. Both $\mathrm{Sll}$ and S2 1 contained about $30 \mathrm{~mol}$ perovskite vs $45 \mathrm{~mol}$ reported by Ringwood. For $\mathrm{UO}_{2}$, our analysis showed good agreement with Ringwood's values for both the perovskite and $z$ irconolite phases. Overall, we believe our analyses agree very well with those of Ringwood. 
COMPOSITE WASTE FORMS ( $S 21, S 29, S 20)$ AND HOLLANDITES $(S 18, S 03 a)$

We prepared three composite waste- form samples (Append $i x$ B). Two samples (S21-S18 and S29) were sent to SRL for CLT. The third sample (S20-S03a) was used in mechanical and thermophysical property studies at LLN,. A portion of this third sample was sent to Argonne National Laboratory (Argonne, IL) for brittle fracture impact studies. The $\mathbf{5 2 0 - 5 0 3 a}$ waste form was nearly identical to the $521-518$ sample.

The two composite waste-form samples for CLT differed mainly in the way cesium was added. In $521-518$, the cesium was first incorporated in hollandite (S18) and then added to the main waste-form starting powier (S21). In S29, cesium was added directly to the main waste form as a water-soluble salt $\left(\mathrm{CsNO}_{3}\right)$ and then immobilized as nepheline/pollucite in the final synthesis step.

A more complete description of the formulation procedures used to prepare CLT sampl is may be found in a report by Ryerson, Burr, and Rozsa. 22 As one example, we show the formulation of 529 in Table 6. The nominal S29 sludge composition without Synroc additives was taken from Append $i x$ and is expressed as moles of oxide per kilogram of sludge. Both uranium and manganese oxides were converted to the reduced oxides $\mathrm{UO}_{2}$ and $\mathrm{Mno}$, respectively; all sndium was converted to $\mathrm{Na}_{2} \mathrm{O}$. We arbitrarily added a slight excess of each Synroc component as a safety margin.

The following steps were used to determine the amount of each additive that must be added to the composite sludge to make $\$ 29$ :

1. $\mathrm{Na}_{2} \mathrm{O}$ and $\mathrm{Cs}_{2} \mathrm{O}$ in Nephel ine ( $\left.\mathrm{Na}_{2} \mathrm{O}_{-\mathrm{Al}}{ }_{2} \underline{\mathrm{O}}_{3} \cdot 2 \mathrm{SiO}_{2}\right)$. We first determined the amount of $\mathrm{SiO}_{2}$ and $\mathrm{Al}_{2} \mathrm{O}_{3}$ needed to give a mol ratio of $2.0\left[\mathrm{SiO}_{2} /\left(\mathrm{Na}_{2} \mathrm{O}+\mathrm{Cs}_{2} \mathrm{O}\right)\right]$. For example, $0.94 \mathrm{~mol}$ of $\mathrm{Na}_{2} \mathrm{O}+\mathrm{Cs}_{2} \mathrm{O}$ required $1.88 \mathrm{~mol}$ of $\mathrm{SiO}_{2}$ and $0.94 \mathrm{~mol}$ of $\mathrm{Al}_{2} \mathrm{O}_{3}$. Because the sludge already contained $0.17 \mathrm{~mol} \mathrm{SiO}_{2}$ and $2.91 \mathrm{~mol} \mathrm{Al}_{2} \mathrm{O}_{3}$, only $1.71 \mathrm{~mol}$ of $\mathrm{SiO}_{2}$ was needed. We added $1.75 \mathrm{~mol}$ of $\mathrm{SiO}_{2}$, which included a slight excess.

2. $\mathrm{UO}_{2}$ in Zirconolite $\left(\mathrm{CaO}^{\circ} \mathrm{ZrO}_{2} \cdot 2 \mathrm{TiO}_{2}\right)$. We used the data in Tables 3 and 5 , which give the $\mathrm{vO}_{2}$ concentrations in zirconolite for the composite sludge as $4.1,3.5$ (S11), and 2.7 (S21) mol\%, respectively. Uranium can substitute for zirconium in the zirconolite lattice, and the $\mathrm{UO}_{2} /\left(\mathrm{ZrO}_{2}+\mathrm{UO}_{2}\right)$ ratios from Ringwood's composite (Table 3 ) and $\$ 11$ and $\$ 21$ (Table 5) were $0.13,0.14$, and 0.15 , respectively. This was remarkably good agreement. We 
Table 6. S29 Reference Synroc D formulation for SRL composite sludge.

\begin{tabular}{|c|c|c|c|c|c|c|}
\hline \multirow[b]{2}{*}{ Oxide } & \multirow{2}{*}{$\begin{array}{l}\text { Composition of } \\
\text { sludge vith } \\
\text { additives (wtz) }\end{array}$} & \multirow{2}{*}{$\begin{array}{l}\text { Oxide } \\
\text { present } \\
\text { (mol/kg } \\
\text { sludge) }\end{array}$} & Amount nergded & to form mineral & phase (mol/kg & sludge) \\
\hline & & & Nepheline ${ }^{b}$ & Zirconolite & Perovskite & Spinele \\
\hline \multicolumn{7}{|c|}{ Oxide sludge, unwashed } \\
\hline Fe0 & - & - & & & & 1.8 \\
\hline $\mathrm{Fe}_{2} \mathrm{O}_{3}$ & 38.0 & 2.38 & & & & 0.5 \\
\hline $\mathrm{Al}_{2} \mathrm{O}_{3}$ & 29.7 & 2.91 & 0.94 & & & 0.7 \\
\hline $\mathrm{HnO}_{2}$ & 11.8 & $1.36 \mathrm{f}$ & & & & 0.7 \\
\hline $\mathrm{U}_{3} \mathrm{O}_{8}$ & 3.3 & 0.123 & & 0.12 & & \\
\hline $\mathrm{CaO}$ & 2.9 & 0.52 & & 0.5 & & \\
\hline Nio & 4.8 & 0.64 & & & & 0.3 \\
\hline $\mathrm{SiO}_{2}$ & 1.0 & 0.17 & 1.7 & & & \\
\hline $\mathrm{Na}_{2} \mathrm{O}$ & 5.3 & $0.93^{\mathrm{h}}$ & 0.93 & & & \\
\hline $\mathrm{Na}_{2} \mathrm{SO}_{4}$ & 1.0 & & & & & \\
\hline $\mathrm{Cs}_{2} \mathrm{O}$ & 0.4 & 0.01 & 0.01 & & & \\
\hline Sro & 0.4 & 0.04 & & & 0.04 & \\
\hline $\mathrm{Ce}_{2} \mathrm{O}_{3}$ & 0.8 & 0.02 & & & & \\
\hline $\mathrm{Nd}_{2} \mathrm{O}_{3}$ & $\frac{0.8}{100.2}$ & 0.02 & & & & \\
\hline \multicolumn{2}{|c|}{ Synroc additives } & \multicolumn{5}{|c|}{ Moles added ${ }^{i}$} \\
\hline $\mathrm{TiO}_{2}$ & & 3.8 & & 1.2 & 1.5 & 0.7 \\
\hline $\mathrm{ZrO}_{2}$ & & 0.9 & & 0.8 & & \\
\hline $\mathrm{CaO}$ & & 1.6 & & & 1.5 & \\
\hline $\mathrm{SiO}_{2}$ & & 1.8 & 1.7 & & & \\
\hline
\end{tabular}

a Unwashed composite sludge from Southwestern Analytical Chemicals, Inc. containing additives from LLNL to simulate DP-1545.

b $\mathrm{Na}_{2} \mathrm{O} \cdot \mathrm{Al}_{2} \mathrm{O}_{3} \cdot 2 \mathrm{SiO}_{2}$; the mol ratio of $\mathrm{SiO}_{2} /\left(\mathrm{Na}_{2} \mathrm{O}+\mathrm{Cs}_{2} \mathrm{O}\right)$ is 2.0 .

c Table 4, composite.

d Contains 1.3 molz of strontium.

e Table 4; the ratio of $\mathrm{FeO} / \mathrm{Fe}_{2} \mathrm{O}_{3}$ is 3.4 .

E Mno.

$8 \mathrm{UO}_{2}$.

h Total Na2O.

i slight excess added.

used Ringwood's composite composition for zirconolite to determine the $\mathrm{TiO}_{2}$, $\mathrm{ZTO}_{2}$, and $\mathrm{CaO}$ additions for $\mathrm{S} 29$. Our composite sludge contained $0.12 \mathrm{~mol} / \mathrm{kg}$ $\mathrm{UO}_{2}$, which required that $2.9 \mathrm{~mol}$ of zirconolite be zlded. This in turn required adding $1.2 \mathrm{~mol} / \mathrm{kg} \mathrm{TiO}, 0.8 \mathrm{~mol} / \mathrm{kg} \mathrm{ZrO}_{2}$, and $0.5 \mathrm{~mol} / \mathrm{kg} \mathrm{CaO}$.

Because the sludge already contained $0.5 \mathrm{~mol} / \mathrm{kg}$ of $\mathrm{JaO}$, only the amounts of $\mathrm{TiO}_{2}$ and $\mathrm{ZrO}_{2}$ are 1 isted as Synroc additions (Table 6).

3. SrO in Perovskite $\left(\mathrm{CaO}^{\circ} \mathrm{TiO}_{2}\right)$. We could only use our estimates of sro concentrations (Table 5 ) as a guide because we had difficulties analyzing the low strontium concentrations in these compositions. For S29, we 
arbitrarily set the molar concentration of SrO in perovskite at 1.3 mol\%, which is higher than the value reported in Table 5. Using this criterion, $0.04 \mathrm{~mol} / \mathrm{kg}$ of $5 r 0$ requires that $3.0 \mathrm{~mol}$ of perovskite $\left(1.5 \mathrm{~mol} / \mathrm{kg}\right.$ of $\mathrm{TiO}_{2}$ and $1.5 \mathrm{~mol} / \mathrm{kg}$ of $\mathrm{CaO}$ ) be made to immobilize Sro. Since the CaO initially present in the sludge was already comitted to forming zirconolite, both $\mathrm{TiO}_{2}$ and the additional $\mathrm{CaO}$ are 1 isted in Table 6 as Synroc additives.

4. $\mathrm{TiO}_{2}, \mathrm{ZrO}_{2}$ and $\mathrm{CaO}$ in Spinel. Our microprobe analysess showed insignificant amounts of $\mathrm{ZrO}_{2}$ and $\mathrm{CaO}$ ( $\mathrm{Tables} 3$ and 5 ) in the spinel phase. However, there were significant amounts of $\mathrm{TiO}_{2}$ in the spinel phases that must be taken into account. Our average $\mathrm{TiO}_{2}$ concentracion for the two spinels was about $14 \mathrm{~mol}$ (Table S) vs Ringwood's value of 10 molz for a single-phase spinel ( $T a b l e ~ 3)$.

We used Ringwood's analysis to calculate the amount of $\mathrm{TiO}_{2}$ required to form the spinel phases. In this case, we first determined that the $\mathrm{FeO} \mathrm{Fe}_{2} \mathrm{O}_{3}$ mol ratio in composite spinel listed in Table 3 was 3.4; we then converted the $2.38 \mathrm{~mol} / \mathrm{kg} \mathrm{Fe} \mathrm{O}_{3}$ for $\mathrm{S} 29$ in Table 6 to $0.54 \mathrm{~mol} / \mathrm{kg}$ $\mathrm{Fe}_{2} \mathrm{O}_{3}$ and $1.84 \mathrm{~mol} / \mathrm{kg} \mathrm{FeO}$. The mol ratio of $\mathrm{TiO}_{2} / \mathrm{FeO}$ from Table 3 was 0.4 . Therefore, the amount of $\mathrm{TiO}_{2}$ required for the spinel phase in $\mathrm{S} 29$ was $0.71 \mathrm{~mol} / \mathrm{kg}$.

Finally, Table 6 gives the molar concentration of $\mathrm{Al}_{2} \mathrm{O}_{3}$ needed to form the composite spinel $(0.7 \mathrm{~mol} / \mathrm{kg})$. Formation of both the spinel and nepheline requires $1.66 \mathrm{~mol} / \mathrm{kg}$ of $\mathrm{Al}_{2} \mathrm{O}_{3}$--well below the $2.91 \mathrm{~mol} / \mathrm{kg}$ that is available in the sludge. However, for high-iron formulations, the $\mathrm{Al}_{2} \mathrm{O}_{3}$ concentrations in the sludge were low, requiring that additional $\mathrm{Al}_{2} \mathrm{O}_{3}$ be added as a synroc ingredient.

5. Rare Earth $0 x i d e s \mathrm{Ce}_{2} \underline{0}_{3}$ and $\mathrm{Nd}_{2}{ }_{-3}$. We did not specifically calculate Synroc additives for rare earth oxides in 529 . As shown in Tables 3 and 5 , the rare earth oxides partition into both zirconolite and perovskite phases to the extent of 2-3 mol\% (total rare earths). We believed that the amounts of zirconolite and perovskite already added to $\mathrm{S} 29$ to immobilize $\mathrm{UO}_{2}$ and Sro would adequately accommodate the rare earth oxides.

The compositions of $\mathrm{S} 21-518$ and $\mathrm{S} 20-\mathrm{SO} 3 \mathrm{a}$ were formulated in the same manner except that hollandite rather than nepheline was selected as the mineral host for cesium. Table 7 shows the composition and process description of $\mathrm{S} 18$ hollandite and a second improved hollandite designated SAN. This improved hollandite was added to the high-iron waste form and is discussed below. 
Table 7. Hollandites (S1B, SAN, and SO3a) added to Synroc D coxposite ( $S 21-518$ and $S 20-S 03 a$ ) and high-icon (S26-SAN) vase forws.

\begin{tabular}{|c|c|c|c|c|c|}
\hline \multirow{2}{*}{$\begin{array}{l}\text { Hollandite } \\
\text { type }\end{array}$} & \multicolumn{3}{|c|}{ Oxide } & \multirow{2}{*}{$\begin{array}{l}\text { Hollandice added } \\
\text { ( } / \text { /kg Synroc D } \\
\text { oxide sludge) }\end{array}$} & \multirow[b]{2}{*}{ Process conditions } \\
\hline & & $(w t z)$ & $(m o 1 x)$ & & \\
\hline S18-HP3Aa & $\begin{array}{l}\mathrm{TiO}_{2} \\
\mathrm{Al}_{2} \mathrm{O}_{3} \\
\mathrm{BaO} \\
\mathrm{Cs}_{2} \mathrm{O}\end{array}$ & $\begin{array}{r}67.4 \\
12.4 \\
16.8 \\
3.4 \\
100.0\end{array}$ & $\begin{array}{r}77.6 \\
11.2 \\
10.1 \\
1.1 \\
100.0\end{array}$ & 75.7 & 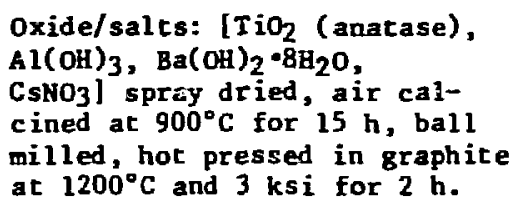 \\
\hline SAN-HP4AB & $\begin{array}{l}\mathrm{TiO}_{2} \\
\mathrm{Al}_{2} \mathrm{O}_{3} \\
\mathrm{BaO} \\
\mathrm{Cs}_{2} \mathrm{O}\end{array}$ & $\begin{array}{r}72.3 \\
13.0 \\
9.1 \\
5.6 \\
100.0\end{array}$ & $\begin{array}{r}81.4 \\
11.5 \\
5.3 \\
1.8 \\
100.0\end{array}$ & 48.9 & $\begin{array}{l}\text { Tetraisopropyl titanate (TIPT) } \\
\text { reacted with methanol solution } \\
\text { of CsOH + Ba(OH) } 2 \text {. Then re- } \\
\left.\text { acted with aq. Al( } \mathrm{NO}_{3}\right)_{3} \text {. Air } \\
\text { dried and calcined at } 650^{\circ} \mathrm{C} \text {; hot } \\
\text { pressed at LLN in graphite at } \\
1200^{\circ} \mathrm{C} \text { and } 3.5 \mathrm{ksi} \text { for } 1 \mathrm{~h} \text {. }\end{array}$ \\
\hline
\end{tabular}

a Crushed; particle size $=1.00-0.42 \mathrm{~mm}$, density $=4.23 \mathrm{~g} / \mathrm{cm}^{3}$, porosity $=5.17$. S03a Hollandice uas prepared by a similar procedure.

b Crushed, particle size $=1.00-0.42 \mathrm{~mm}$, density $=4.15 \mathrm{~g} / \mathrm{cm}^{3}$. Prepared by R. G. Dosch, Sand ía National Laboratories, Albuquerque, NM. (Ref. 24).

HIGH-IRON WASTE FORMS ( 226, S30) AND HOLLANDITE (SAN)

We prepared two high-iron waste form samples (S26-SAN and S30) for CLT. The overall compositions are listed in Appendix B. As in the case for composite waste forms, the primary difference between S26-SAN and S30 is the manner in which cesium was added. For example, Table 8 shows the 530 formulation. Although the formulation process used for high-iron sludge was similar to that used for the composite sludge, there were some important differences :

1. Because the uranium oxide concentration in high-iron sludge was considerably higher than in the composite, more zirconolite was required in this waste form. To determine the zirconolite components needed, we used Ringwood's analysis ${ }^{4}$ for high-iron sludge (Table 3 ). In his analysis, the $\mathrm{UO}_{2}$ concentration in zirconolite was slightly higher than that used in our 529 composite zirconolite. The $\mathrm{UO}_{2} /\left(\mathrm{ZrO}_{2}+\mathrm{UO}_{2}\right)$ ratio for Ringwood's high-iron material was 0.22 vs 0.13 for our 529 composite material. 
Table 8. S30 Reference Synroc D formulation for SRL high-iron sludge.

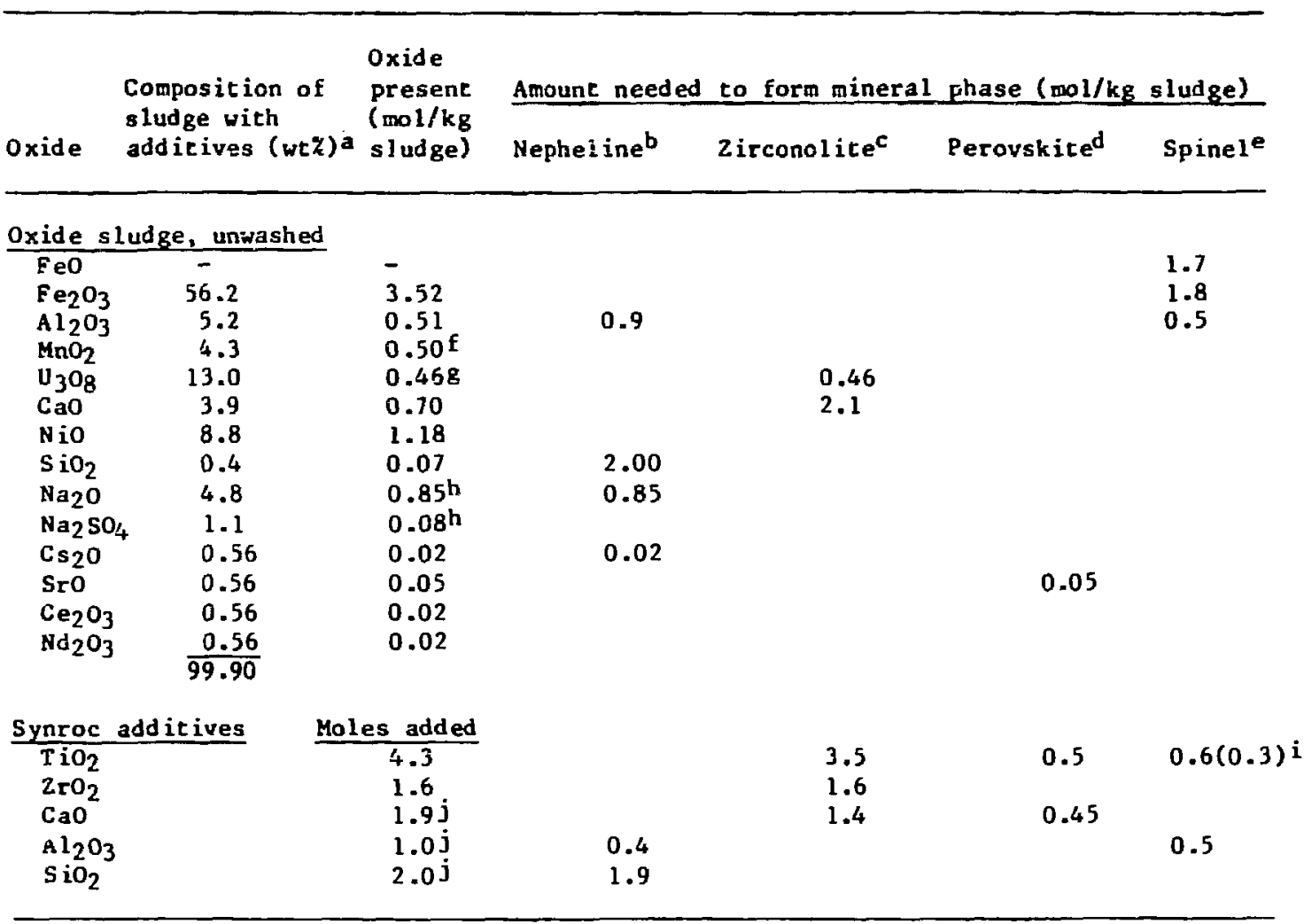

a Unwashed high-iron sludge from Southwestern Analytical Chemicals, Inc. containing additives to simulate DP- 1545 .

b $\mathrm{Na}_{2} \mathrm{O} \cdot \mathrm{Al}_{2} \mathrm{O}_{3} \cdot 2 \mathrm{SiO}_{2}$; the mol ratio of $\mathrm{SiO}_{2} /\left(\mathrm{Na}_{2} \mathrm{O}+\mathrm{Cs}_{2} \mathrm{O}\right)$ is 2.3 .

c Table 4, high iron.

d Contains 5.0 mol\% of strontium.

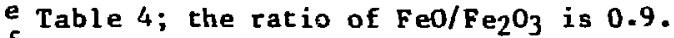

f MnO.

g $\mathrm{UO}_{2}$.

h Total $\mathrm{Na}_{2} \mathrm{O}$.

i Formation of spinel required $0.6 \mathrm{~mol} / \mathrm{kg}$ and $0.3 \mathrm{~mol} / \mathrm{kg}$ were added.

j slight excess added.

2. A slight excess of $\mathrm{SiO}_{2}$ was added to insure complete synthesis of nepheline. 23 The $\mathrm{SiO}_{2} /\left(\mathrm{Na}_{2} \mathrm{O}+\mathrm{Cs}_{2} \mathrm{O}\right)$ ratio was 2.3 vs 2.0 in the $\mathrm{s} 29$ composite waste form.

3. The concentration of Sro in perovskite was increased from 1.3 mols to $5.0 \mathrm{~mol} \%$.

4. The iron oxide in the spinel phase was not reduced as much as in the composite waste form. The $\mathrm{FeO} / \mathrm{Fe}_{2} \mathrm{O}_{3}$ mol ratio was 0.9 according to Ringwood (Table 3 ) vs 3.4 in our composite. 
5. We formulated $\mathrm{S} 30$ with less $\mathrm{TiO}_{2}$ in the spinel thase than was used in 526 . We added $4.3 \mathrm{~mol} \mathrm{TiO} / 2 / \mathrm{kg}$ of sludge (Table 8 ). Of this amount, 4.0 mol/kg was allocated to $z$ irconolite and perovskite, leaving the balance $(0.3$ mol $/ \mathrm{kg}$ ) to spinel--even though $0.6 \mathrm{~mol} / \mathrm{kg}$ was needed for a high-iron spinel, according to Table 3 . He formulated 526 in accordance with Table 3 using a small overall excess of $\mathrm{TiO}_{2}$.

6. There was insufficient $\mathrm{Al}_{2} \mathrm{O}_{3}$ in the sludge, which required that we add 0.9 mol $\mathrm{Al}_{2} \mathrm{O}_{3} / \mathrm{kg}$ sludge as a Synroc additive.

Table 7 gives the composition and process description of the hollandite (SAN) that was added to $\mathrm{S26}$. This hollandite precursor powder was prepared at Sandia National Laboratory by Dosch ${ }^{24}$ and then hot pressed at LLNL.

HIGH-ALUMINUM WASTE FORM (S31)

In our high-alumina waste form ( $\$ 31$;, we adjusted the initial composition by adding $\mathrm{Fe}_{2} \mathrm{O}_{3}$ to nearly duplicate the composite sludge and adopted the same formulation procedure used for the composite waste form 529 . Because of this $\mathrm{Fe}_{2} \mathrm{O}_{3}$ addition to $\mathrm{s} 31$, the radwaste components were more dilute than in the $\$ 29$ composition.

The overall composition is given in Appendix $B$.

\section{WASTE FORM PREPARATION}

S29--THE REFEREHCE SYNROC D COMPOSITE WASTE FORM

We designated 529 as our reference waste form. On the basis of our experience gained by preparing several waste compositions, we believe that 529 demonstrates the potential for a procedure for the large-scale remote processing of high-level defense waste. Ref. 25 gives a more detailed description of large-scale Synroc processing.

In Fig. 3, a basic flow diagram shows the processing steps for preparing S29. Precise formulation and microstructural characterization were not a major requirement. Good mixing and homogenization at the slurry-powder preparation stage using conventional spray-drying technology was successful; grinding and milling steps were not required. The redox control of the iron 
Prepare aqueaus slurry of simulated SRL waste

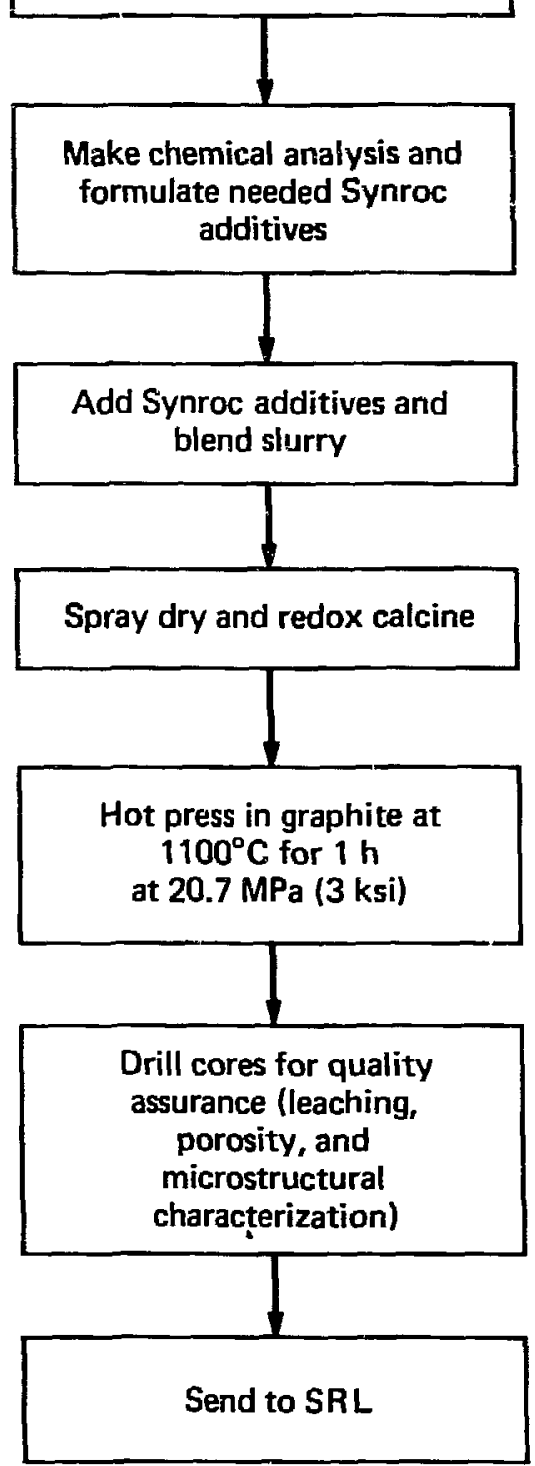

Figure 3. Processing steps for preparing sample S29, the reference Synroc D composite waste form. 
oxidation state was very flexible. The final step of densification and mineralization was achieved at very modest temperatures and time periods, which permits the application of conventional, well-understood ceramic technology in the fields of sintering and hot isostatic pressing.

We generally used the same procedure to prepare all Syoroc D CLT samples. In the following sections, we use $S 21$ powder with SRL simulated waste as an example. It was the first powder prepared for CLT and its preparation is representative of Reference $S 29$ and all subsequent preparation steps except that:

1. The mineral host selected for cesium was changed from hollandite to nepheline (except for high-iron S26-SAN).

2. Powder grinding proved unnecessary for adequate mixing and was eliminated in all subsequent CLT preparations.

3. Redox calcination temperatures were reduced from $965^{\circ} \mathrm{C}$ to $800^{\circ} \mathrm{C}$ in all later CLT preparations because the lower temperature is more desirable for large-scale processing, and it reduced the risk of forming unwanted precursor mineral phases such as ilmenite.

\section{STARTING MATERIALS}

In Table 9, we categorize all spray-dry batches according to the type of sludge used and the salt/oxide components added to make up the sliurry mixtures for spray drying. The preparation of dried sludges by SRL is discussed in Appendix B. Table 10 compares the results of our chemical analyses of sludges received from SRL listed in Table 10 to the nominal SRL compositions (taken from Appendix B). The values generally agree well except that our values for rare earth oxides $\mathrm{Ce}_{2} \mathrm{O}_{3}$ and $\mathrm{Nd}_{2} \mathrm{O}_{3}$ in the composite sludge were about 0.5 wtZ vs $1.0 \mathrm{wtZ}$ nominal reported by SRL. We used the SRL values in our formulated composite compositions.

For the additive salts listed in Table 9, we determined in advance the oxide equivalents of each salt. The SkL sludges were powders derived from slurry solutions that had been dried by an air sparge using low heat to evaporate the water. He conducted an initial test of the GRL powder for water-soluble oxides on only the "as-received" composite sludge. About $1.5 \mathrm{~g}$ of sludge powder was stirred in $100 \mathrm{ml}$ of distilled water at room temperature for $16 \mathrm{~h}$. Table 11 shows the spectrochemical analysis of the leachate. The 
Table 9. Starting materials for Synroc D waste-form preparation.

Spray-dry batch number

\begin{tabular}{|c|c|c|c|c|c|c|c|c|c|}
\hline \multirow[b]{3}{*}{ sludge type } & \multicolumn{9}{|c|}{ Spray-dry batch number } \\
\hline & \multicolumn{3}{|c|}{ Composice } & \multicolumn{2}{|c|}{ High iron } & \multirow{2}{*}{\multicolumn{2}{|c|}{$\frac{\text { high aluminum }}{\text { s31 }}$}} & \multicolumn{2}{|c|}{ holland ite } \\
\hline & $\mathbf{s} 20$ & s21 & $\mathbf{s} 29$ & $\mathbf{S 2 6}$ & $\mathbf{s} 30$ & & & $\$ 18$ & so $3 a$ \\
\hline
\end{tabular}

SRL composite

SRL high iron

SRL high aluminum

$\mathbf{x}$

SAI compositea

SAC high irona

$\mathbf{x}$

$\mathbf{x}$

$\mathbf{x}$

$\mathbf{x}$

oxide Salt

equivalent additive

\begin{tabular}{|c|c|c|c|c|c|c|c|c|c|}
\hline $\mathrm{TiO}_{2}$ & $\mathrm{TiO}_{2}$ (anatase) $^{\mathrm{b}}$ & $x$ & $\mathbf{x}$ & $x$ & $\mathbf{x}$ & $\mathbf{x}$ & $x$ & $\mathbf{x}$ & $\mathbf{x}$ \\
\hline $\mathrm{ZrO}_{2}$ & $\mathrm{Zr}\left(\mathrm{NO}_{3}\right)_{4}^{\mathrm{C}}$ & $x$ & $\mathbf{x}$ & $\mathbf{x}$ & $x$ & $x^{d}$ & $x^{d}$ & & \\
\hline $\mathrm{CaO}$ & $\mathrm{Ca}\left(\mathrm{NO}_{3}\right)_{2} \cdot \mathrm{H}_{2} \mathrm{O}$ & $\mathbf{x}$ & $\mathbf{x}$ & $x$ & $x$ & $\mathbf{x}$ & $\mathbf{x}$ & & \\
\hline $\mathrm{BaO}$ & $\mathrm{Ba}(\mathrm{OH})_{2} \cdot 8 \mathrm{H}_{2} \mathrm{O}$ & & & & & & & $x_{e}$ & $\mathrm{x}_{\mathrm{e}}$ \\
\hline $\mathrm{Al}_{2} \mathrm{O}_{3}$ & $\mathrm{Al}\left(\mathrm{NO}_{3}\right)_{3} \cdot 9 \mathrm{H}_{2} \mathrm{O}$ & $\mathbf{x}$ & $\mathrm{x}$ & $\mathbf{x}$ & $\mathbf{x}$ & $\mathbf{x}$ & $\mathbf{x}$ & $x^{e}$ & $x^{e}$ \\
\hline $\begin{array}{l}\mathrm{Fe}_{2} \mathrm{O}_{3} \\
\mathrm{SiO}\end{array}$ & $\begin{array}{l}\mathrm{Fe}\left(\mathrm{NO}_{3}\right)_{3} \cdot 9 \mathrm{H}_{2} \mathrm{O} \\
\text { Colloidal silicate } \mathrm{F}\end{array}$ & $x$ & $\mathbf{x}$ & $x$ & $x$ & $x$ & $x$ & & \\
\hline $\mathrm{Na}_{2} \mathrm{O}$ & $\mathrm{NaNO}_{3}$ & & & $\mathrm{x}$ & & & & & \\
\hline $\mathrm{Na}_{2} \mathrm{O} \cdot \mathrm{SiO}_{2}$ & $\mathrm{NaO} \cdot \mathrm{SiO}_{2} \cdot \mathrm{H}_{2} \mathrm{O}$ & $\mathbf{x}$ & & & & & & & \\
\hline $\mathrm{Na}_{2} \mathrm{O}$ & $\mathrm{Na}_{2} \mathrm{SO}_{4}$ & $\mathbf{x}$ & & & & $\mathbf{x}$ & & & \\
\hline $\mathrm{UO}_{2}$ & $\mathrm{UO}_{2}\left(\mathrm{NO}_{3}\right)_{2} \cdot 6 \mathrm{H}_{2} \mathrm{O}$ & $\mathbf{x}$ & & $\mathbf{x}$ & & $\mathbf{x}$ & & & \\
\hline $\mathrm{Cs}_{2} \mathrm{O}$ & $\mathrm{CsNO}_{3}$ & & & $x$ & & $x$ & $\mathbf{x}$ & $\mathbf{x}$ & \\
\hline Sro & $\mathrm{Sr}\left(\mathrm{NO}_{3}\right)_{2}$ & $\mathbf{x}$ & & $\mathbf{x}$ & & $\mathbf{x}$ & & & \\
\hline $\mathrm{Ce}_{2} \mathrm{O}_{3}$ & $\mathrm{Ce}\left(\mathrm{NO}_{3}\right)_{3} \cdot 6 \mathrm{H}_{2} \mathrm{O}^{8}$ & $\mathbf{x}$ & & $\mathbf{x}$ & & $\mathbf{x}$ & & & \\
\hline $\mathrm{Nd}_{2} \mathrm{O}_{3}$ & $\mathrm{Nd}\left(\mathrm{NO}_{3}\right)_{3} \cdot 5 \mathrm{H}_{2} \mathrm{O}^{8}$ & $\mathbf{x}$ & & $\mathbf{x}$ & & $x$ & & & \\
\hline $\mathrm{Eu}_{2} \mathrm{O}_{3}$ & $\mathrm{Eu}\left(\mathrm{NO}_{3}\right)_{3}=5 \mathrm{H}_{2} 0^{\mathrm{g}}$ & $x$ & & & & & & & \\
\hline $\mathrm{Ge}_{2} \mathrm{O}_{3}$ & $\mathrm{Ge}\left(\mathrm{NO}_{3}\right)_{3} \cdot 5 \mathrm{H}_{2} \mathrm{O}^{\mathrm{g}}$ & $x$ & & & & & & & \\
\hline
\end{tabular}

a Simulated sludge prepared by Southwestern Analytical Chemicals, Austin, TX.

b Pigment Grade Titanox 1000, supplied by NL Chemicals Co., South Amboy, NJ.

c Prepared by BDH, England, and supplied by Gallard Schlesinger, Carle Place, NY.

Calcined at $300^{\circ} \mathrm{C}$ to $\mathrm{ZrO}_{2}$ before adding to sludge.

$\mathrm{d} Z$ irconium added as the nitrate.

e Added as $\mathrm{Al}(\mathrm{OH})_{3}$.

f Supplied as ammonium-stabilized Ludox colloidal. silica by E.I. du Pont de Nemours and Co., Wilmington, DE.

g Supplied by Research Chemicals, Phoenix, AZ. 
Table 10. Chemical analyses of "as received" dried sludges from the Savannah River Laboratory.

\section{Composition (nominal wt\%)}

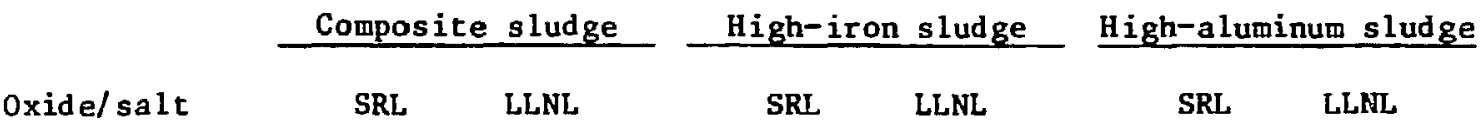

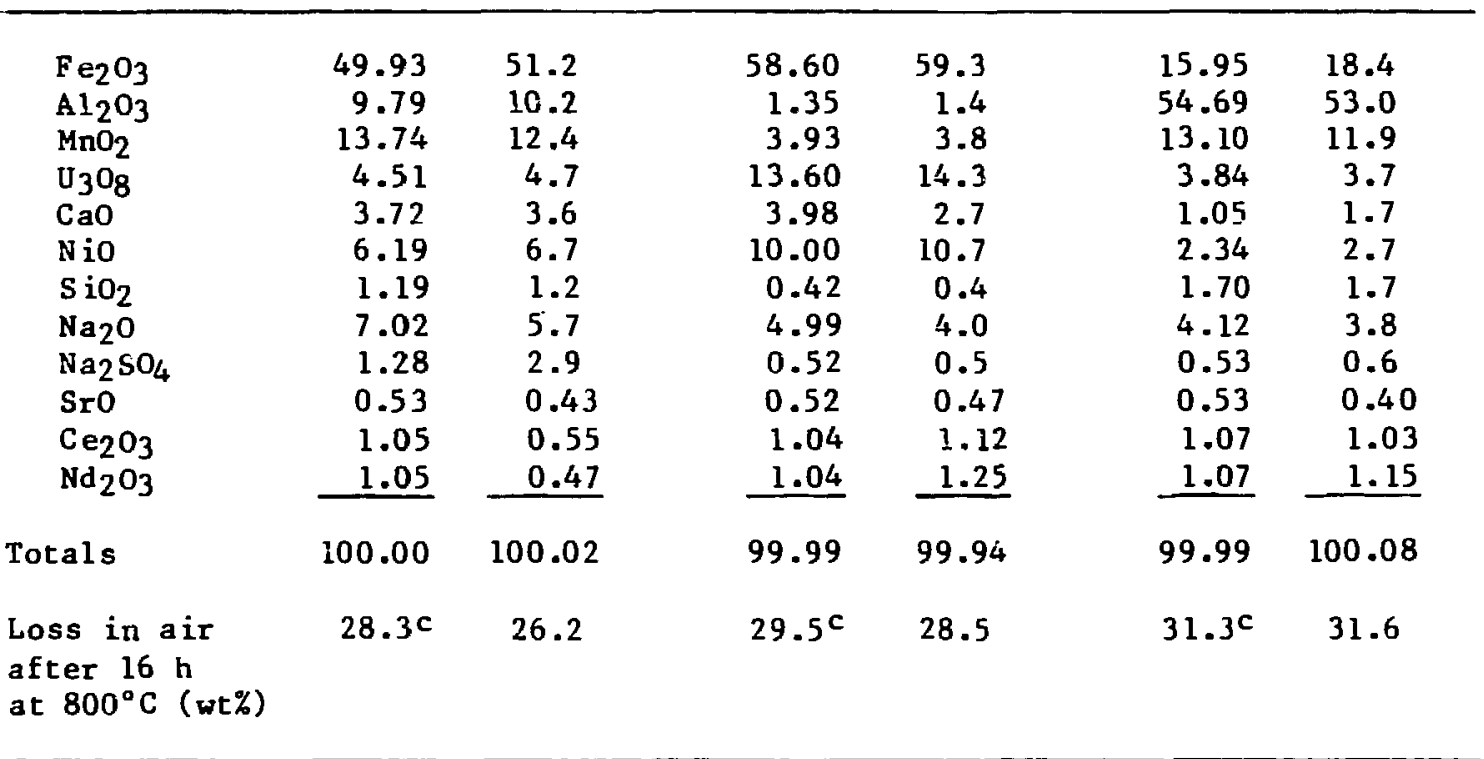

a Atomic absorption analyses were performed by Bob Lim, and $x$-ray fluorescence analyses were performed by Richard Ryan, both at LLNL.

b Data taken from Append ix A.

c SRL weight losses in air after $96 \mathrm{~h}$ at $900^{\circ} \mathrm{C}$.

leachate indicated very low concentrations of all elements except sodium, which was expected. On the basis of $200 \mathrm{\mu g} \mathrm{Na}{ }_{2} \mathrm{O} / 100 \mathrm{ml}$ leachate, we estimated that about $1.8 \mathrm{wt} \%$ of $\mathrm{Na}_{2} \mathrm{O}$ was leached from the powder vs the 5.7 wt initially present in the starting sludge. This low rate of sodium dissolution may result from the fact that the simulated SRL sludge was dried at low temperatures.

To demonstrate the differences between formulated and mixed compositions for a large batch of sludge, we compare three different analyses of random samples in Table 12. These samples were taken from about $2.2 \mathrm{~kg}$ of $52 \mathrm{l}$

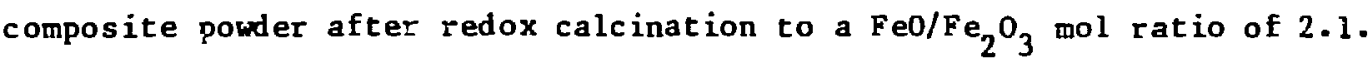
In Table 13, we show the analyses of two hot-pressed composite samples (S21-S18 and S29) and one high-iron sample (S26-SAN). There is generally good 
Table 11. Spectrochemical analysis of aqueous phase after separation from simulated SRL composite sludge/water slurry after stirring $16 \mathrm{~h}$ at room temperature.

\section{Elements detected}

\begin{tabular}{lccc}
\hline Element & $\begin{array}{l}\text { Concentrationa } \\
(\mu \mathrm{g} / \mathrm{ml})\end{array}$ & Element & $\begin{array}{l}\text { Concentrationa } \\
(\mu \mathrm{g} / \mathrm{ml})\end{array}$ \\
\hline $\mathrm{Na}$ & $\geq 200^{\mathrm{b}}$ & $\mathrm{Ba}$ & 0.1 \\
$\mathrm{U}$ & $\geq 30^{\mathrm{c}}$ & $\mathrm{Fe}$ & 0.1 \\
$\mathrm{Al}$ & 20 & $\mathrm{~B}$ & 0.06 \\
$\mathrm{Ca}$ & 6 & $\mathrm{Sr}$ & 0.06 \\
$\mathrm{Zn}$ & 5 & $\mathrm{Mg}$ & 0.02 \\
$\mathrm{Si}$ & 0.4 & $\mathrm{Ag}$ & $\$ 0.006$ \\
$\mathrm{Cr}$ & 0.2 & $\mathrm{Cu}$ & 0.006 \\
\hline
\end{tabular}

Elements not detected

Element

Limit of detection ( $\mu g / m l)$
$\mathrm{Sm}, \mathrm{Tb}$
$<2$
Dy, Gd, Ge, Ho, La, Lu, Nb, Nd, Pr, Sb, Sc, Zr
$<0.2$
$\mathrm{Er}, \mathrm{Eu}, \mathrm{Ni}, \mathrm{Pb}, \mathrm{Tm}, \mathrm{V}, \mathrm{Y}$
$<0.06$
$B i, C d, S n, T i, Y b$
$<0.02$
Be, Co, Mo, Mn
$<0.006$

a $1.4 \mathrm{~g}$ dried, simulated sludge leached in $100 \mathrm{ml}$ water.

b About 1.8 wtz Na2O.

c About $0.002 \mathrm{wt} \% \mathrm{UO}_{2}$.

agreement between nominal and measured compositions in both the caicined powder and hot pressed stages of Synroc D synthesis. Since then, we have prepared batches of up to $65 \mathrm{~kg}$ of powder and have observed little or no variation in composition within the bacch.

\section{SLURRY PREPARATION}

To prepare simulated SRL composite sludge for slurry mixing and spray drying, $2 \mathrm{~kg}$ of the powder was first divided into four 500-g portions. Each 
Table 12. Analyses of 521 composite waste-form powder after redox calcination in a carbon monoxide-carbon diaxide $(10: 1)$ gas environment at $965^{\circ} \mathrm{C}$ for about $10 \mathrm{~h}$ in a rotary kiln.

\section{Composition (wtz)}

Oxide As formulated Atomic absorption X-ray fluorescence

\begin{tabular}{|c|c|c|c|c|}
\hline $\mathrm{Fe}_{2} \mathrm{O}_{3}$ & 24.7 & 26.1 & 28.3 & 24.4 \\
\hline $\mathrm{Al}_{2} \mathrm{O}_{3}$ & 19.3 & 19.6 & 18.5 & - \\
\hline $\mathrm{MnO}_{2}$ & 6.0 & 6.2 & 6.5 & 7.3 \\
\hline $\mathrm{U}_{3} \mathrm{O}_{8}$ & 2.3 & - & 2.4 & 1.9 \\
\hline $\mathrm{CaO}$ & 7.2 & 7.5 & 9.1 & 8.4 \\
\hline $\mathrm{NiO}$ & 3.2 & 3.2 & 3.1 & 2.3 \\
\hline $\mathrm{Na}_{2} \mathrm{O}$ & $3.4^{b}$ & 3.4 & 3.8 & - \\
\hline $\mathrm{SiO}_{2}$ & 7.2 & - & 10.1 & - \\
\hline Sro & 0.25 & 0.21 & 0.21 & 0.19 \\
\hline $\mathrm{Ce}_{2} \mathrm{O}_{3}$ & 0.50 & - & 0.61 & - \\
\hline $\mathrm{Nd}_{2} \mathrm{O}_{3}$ & 0.50 & - & 0.57 & - \\
\hline $\mathrm{TiO}_{2}$ & 18.4 & 14.9 & 13.9 & 21.9 \\
\hline $\mathrm{ZrO}_{2}$ & 6.3 & - & 6.0 & 5.3 \\
\hline Totals & 99.3 & & 103.1 & \\
\hline
\end{tabular}

a Three batches were cone-blended for $2 \mathrm{~h}$ before 6 ampling. The mol ratio of $\mathrm{FeO} / \mathrm{Fe}_{2} \mathrm{O}_{3}$ was 2.3 .

b Total $\mathrm{Na}_{2} \mathrm{O}$ reported, which includes 1.4 wt: $\mathrm{Na}_{2} \mathrm{SO}_{4}$ -

portion was then combined with about $870 \mathrm{~g}$ of an oxide/salt mixture containing the appropriate amounts of each ingredient. Each batch of powder (about $1.4 \mathrm{~kg}$ ) was then combined with about 61 of water and tumbled with a small number of alumina balls for about $16 \mathrm{~h}$ in a large 5-gal plastic container. The container was removed from the roller mill just before spray drying. When using sludges prepared as aqueous slurries from Southwestern Analytical Chemicals, Inc., slurries were mixed homogeneously in barrels before removing known aliquots for subsequent combination with the required additives.

\section{SFRAY DRYING AND CALISINATION}

After the sludge and additives have been slurried, the measured pH was 3 to 5. At these pH levels, the hydrogen-ion concentrations were still quite low and probably insufficient to dissolve significant amounts of the suspended 
Table 13. Analysis of composite ( $\$ 21-S 18$ and S29) and high-iron (S26-SAN) waste forms after hot pressing in graphite.

\begin{tabular}{|c|c|c|c|c|c|c|c|c|}
\hline \multirow[b]{3}{*}{ Oxide } & \multicolumn{8}{|c|}{ Composition (wt $x$ ) } \\
\hline & \multicolumn{4}{|c|}{$s 21-s 18-H P 8 A^{b}$} & \multicolumn{2}{|c|}{ S29-HP8Ac } & \multicolumn{2}{|c|}{ S26-SAN ${ }^{d}$} \\
\hline & Nomina 1 & $\begin{array}{l}\text { Atomic } \\
\text { absorption }\end{array}$ & $\begin{array}{l}X \text {-ray } \\
\text { fluorescence }\end{array}$ & $\begin{array}{l}\text { Electron } \\
\text { microprobe }\end{array}$ & Nominal & $\begin{array}{l}X-r a y \\
\text { fluorescence }\end{array}$ & Nomina 1 & $\begin{array}{l}\text { X-ray } \\
\text { fluoreocence }\end{array}$ \\
\hline $\begin{array}{l}\mathrm{Fe}_{2} \mathrm{O}_{3} \\
\mathrm{Al}_{2} \mathrm{O}_{3} \\
\mathrm{MnO}_{2} \\
\mathrm{U}_{3} \mathrm{O}_{8} \\
\mathrm{CaO} \\
\mathrm{NiO} \\
\mathrm{Na}_{2} \mathrm{O} \\
\mathrm{SiO}_{2} \\
\mathrm{Ca}_{2} \mathrm{O} \\
\mathrm{SrO} \\
\mathrm{Ce}_{2} \mathrm{O}_{3} \\
\mathrm{Nd}_{2} \mathrm{O}_{3} \\
\mathrm{TiO}_{2} \\
\mathrm{ZrO}_{2} \\
\mathrm{BaO}\end{array}$ & $\begin{array}{c}23.0 \\
18.9 \\
5.6 \\
2.1 \\
6.6 \\
3.0 \\
3.2 \\
6.7 \\
0.24 \\
0.24 \\
0.50 \\
0.50 \\
21.85 \\
5.8 \\
1.28 \\
\end{array}$ & $\begin{array}{c}23.3 \\
18.7 \\
5.6 \\
- \\
7.4 \\
3.0 \\
2.8 \\
- \\
- \\
- \\
- \\
- \\
17.9 \\
-\end{array}$ & $\begin{array}{c}25.0 \\
20.0 \\
5.8 \\
2.3 \\
6.6 \\
3.1 \\
2.9 \\
8.2 \\
0.22 \\
0.12 \\
0.55 \\
0.55 \\
18.5 \\
5.9 \\
1.5 \\
\end{array}$ & $\begin{array}{c}22.8 \\
22.1 \\
5.6 \\
2.3 \\
7.7 \\
2.7 \\
4.6 \\
11.7 \\
- \\
- \\
0.38 \\
0.54 \\
21.2 \\
6.2 \\
0\end{array}$ & $\begin{array}{c}23.8 \\
18.6 \\
7.4 \\
2.1 \\
7.1 \\
3.0 \\
3.6 \\
7.2 \\
0.25 \\
0.25 \\
0.50 \\
0.50 \\
18.8 \\
6.6 \\
0 \\
\end{array}$ & $\begin{array}{c}25.3 \\
23.3 \\
7.6 \\
2.4 \\
7.1 \\
3.2 \\
3.2 \\
9.0 \\
0.20 \\
0.14 \\
0.58 \\
0.50 \\
15.3 \\
6.6 \\
0 \\
\end{array}$ & $\begin{array}{r}28.9 \\
6.9 \\
1.9 \\
6.7 \\
7.3 \\
5.2 \\
2.0 \\
4.4 \\
0.25 \\
0.25 \\
0.50 \\
0.50 \\
24.0 \\
10.4 \\
0.4 \\
\end{array}$ & $\begin{array}{c}29.0 \\
7.7 \\
2.9 \\
6.5 \\
7.2 \\
5.4 \\
2.2 \\
5.7 \\
0.20 \\
0.13 \\
0.61 \\
0.50 \\
18.8 \\
8.5 \\
0.6 \\
\end{array}$ \\
\hline Total & 99.41 & & 101.24 & & 99.7 & 104.42 & 99.60 & 94.94 \\
\hline
\end{tabular}

a Ater hot pressing, samples were crushed to $-300 \mu \mathrm{m}$ powder for analysio.

b Hot pressed at $1050^{\circ} \mathrm{C}$ for one hour at $20.7 \mathrm{MPa}$ (3 ksi).

c Hot presaed at $1025^{\circ} \mathrm{C}$ for one hour at $20.7 \mathrm{MPa}$ (3 ksi).

d thot pressed at $1100^{\circ} \mathrm{C}$ for one hour at $20.7 \mathrm{MPa}$ (3 ksi).

e Electron microprobe broad-beam analyais of 521 matrix phase on $2 y$. Values normalized to exclude 7.04 wtY hollandite for $\$ 21-\$ 18$ comparigon. 
SRl sludge in the slurry. In this regard, we believed that the preferential dissolution of radwaste components in actual SRP sludges could make an important contribution to homogeneous wixing before the material was spray dried and that this possibility should receive additional study. We were also concerned that no water-soluble titanium salt was available, which required us to add titanium as pigment-grade $\mathrm{TiO}_{2}$ consisting ố submicron-sized particles. We found, however, that we could achieve goce densification and mineralization using dried SRL simulated sludges and pigment-grade $\mathrm{TiO}_{2}{ }^{*}$

A portable spray dryer with centrifugal atomization and single-point collection in a cyclone separator (Niro Atomizer, Columbia, MD) was used to process all waste-form slurries (Fig. 4). In order to provide feed for spray drying, portions of the slurry were transferred to a large 4-1 beaker and stirred mechanically. The slurry supply to the ciryer was about $70 \mathrm{~cm} / \mathrm{min}$, wich allowed an exit-gas temperature in the range of $132-136^{\circ} \mathrm{C}$. In some cases, however, temperature excursions did occur to a maximum of $150^{\circ} \mathrm{C}$ and a minimum $125^{\circ} \mathrm{C}$. Dried pouder was collected at the base of the cyclone separator in 500-ml bottles (Fig. 4a). The powder production rates of dried uncalcined powder ranged between 9 and $13 \mathrm{~g} / \mathrm{min}(6$ to $9 \mathrm{~g} / \mathrm{min}$ of oxide equivalent, based on an average $30 \%$-weight losses incurred during calcination).

In the laboratory, the spray-dried powders wera calcined in two stages: air calcination and redox calcination. Two-stage calcination made it easier to disposed of decomposition gases; the powders were first air calcined in furnaces inside vented enclosures and then redox calcined in a rotary calciner. In actual processing of defense wastes, a single calcination step would be used.

A total of $4.4 \mathrm{~kg}$ of $\mathrm{S} 21$ powder was produced by the spray dryer. The total solids input to the spray dryer was:

$\begin{array}{ll}\text { Sludge } & 2.0 \mathrm{~kg} \\ \text { Aluminum nitrate } & 3.3 \\ \text { Calcium nitrate } & 0.7 \\ \mathrm{TiO}_{2} & 0.6 \\ \mathrm{ZrO}_{2} & 0.2 \\ \mathrm{SiO}_{2} & \underline{0.7} \\ & \\ \text { Total } & 7.5(3.0 \mathrm{~kg} \text { oxide equivalent })\end{array}$




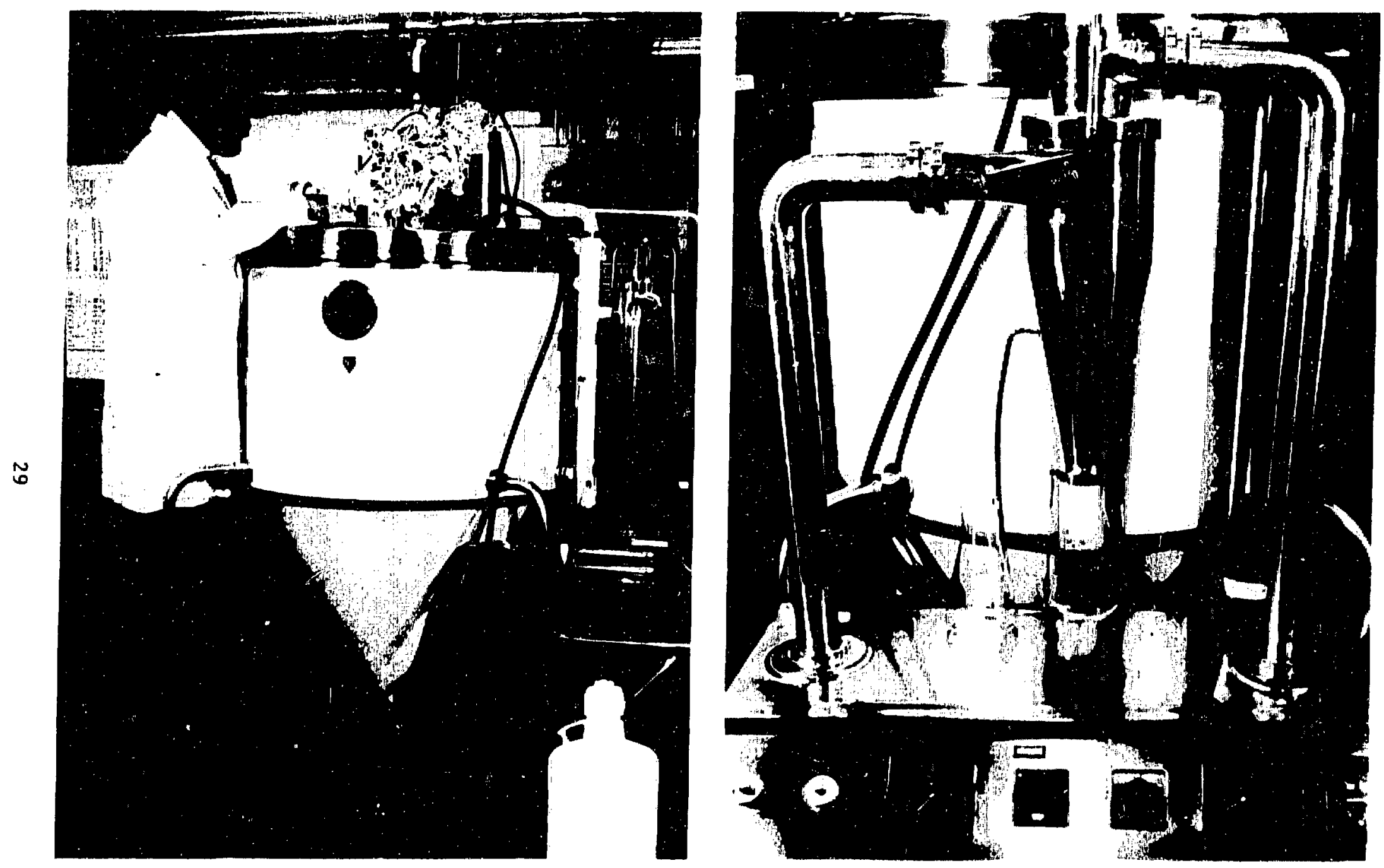

Figure 4. (a) Portable spray dryer with centrifugal atomization that was used to process al1 waste-form slurries. (b) Cyclone separator; dried powder was collected at the separator's base in $500-\mathrm{ml}$ bottles. 
Assuming total loss of water of hydration during drying, the pouder yield would have been $5.33 \mathrm{~kg}$. Our yield of $4.4 \mathrm{~kg}$ indicates that some nitrate decomposition in addition to dehydration occurred during drying.

The spray-died powders were then loaded into large alumina crucibles so that each one was half full and contained about $1 \mathrm{~kg}$ of pouder. The powders were calcined in air to constant weight at $650^{\circ} \mathrm{C}$ for periods of 40 to $53 \mathrm{~h}$. We had previously determined that smaller samples heated in air at $650^{\circ} \mathrm{C}$ achieved a constant weight in 16 hours. The temperature of $650^{\circ} \mathrm{C}$ was selected because earlier work had shown that some mineralization begins at higher calcination temperatures; because we did not want spinel to form under the oxidizing conditions of an air calcine, temperatures at this stage were 1 imited to $650^{\circ} \mathrm{C}$.

The average weight loss for $\mathrm{S} 21$ batches was $38.2 \pm 0.1 \%$. The total oxide weight was $2.7 \mathrm{~kg}$ vs $3.0 \mathrm{~kg}$ oxide calculated from the original formulation. This represents a possible $10 \%$ stack loss (neglecting minor handling losses) in the spray-dryer operation. Since the spray-dryer specifications indicate only a nominal $95 \%$ recovery using this equipment, we were satisfied with our recovery.

The $2.7 \mathrm{~kg}$ of air-calcined $\mathrm{S} 21$ powder was then redox calcined in a rotary kiln-type furnace system (Fig. 5). The reaction vessel was heated in a three-zone split-hinged furnace (Model 54657, Lindberg Furnace Co., Chicago, IL) having $\mathrm{Cr}-\mathrm{Al}-\mathrm{Fe}$ alloy heating elements capable of $1200^{\circ} \mathrm{C}$. The reaction vessel (Fig. 6) was rotated at about one rpm. The powder load limit for this chamber (filled a third full) was about $1 \mathrm{~kg}$. Three batches of 521 powder were calcined at $965^{\circ} \mathrm{C}$ for periods of 5-16 hours in a carbon dioxide-carbon monoxide $(10: 1)$ reducing atmosphere at a total flow rate of about $461 / \mathrm{h}$. Calcination times varied with batch size $(0.85$ to $1.0 \mathrm{~kg})$ and each batch was redox calcined until the $\mathrm{FeO} / \mathrm{Fe}_{2} \mathrm{O}_{3}$ mol ratio was about 2.1 , as determined by wet-chemical analysis. 26

After redox calcination, all three powder batches were blended for $2 \mathrm{~h}$ in a rotating-cone blender with a rapidly rotating disintegrator bar traveling at $2800 \mathrm{rpm}$ (Patterson Industries, Inc., Easi Liverpool, $0 H$ ). Samples were then taken for $x$-ray analysis and some small-scale test hot pressings.

The x-ray analysis of redox-calcined 521 powder indicated some crystallinity. The major phases were two spinels $\left(a^{\circ}=8.45 \AA\right.$ and $\left.a^{\circ}=8.18 \AA\right)$ and perovskite; secondary phases were ilmenite $\left(\mathrm{FeTiO}{ }_{3}\right.$ ) and $\mathrm{ZrO}_{2} \cdot$ Because 

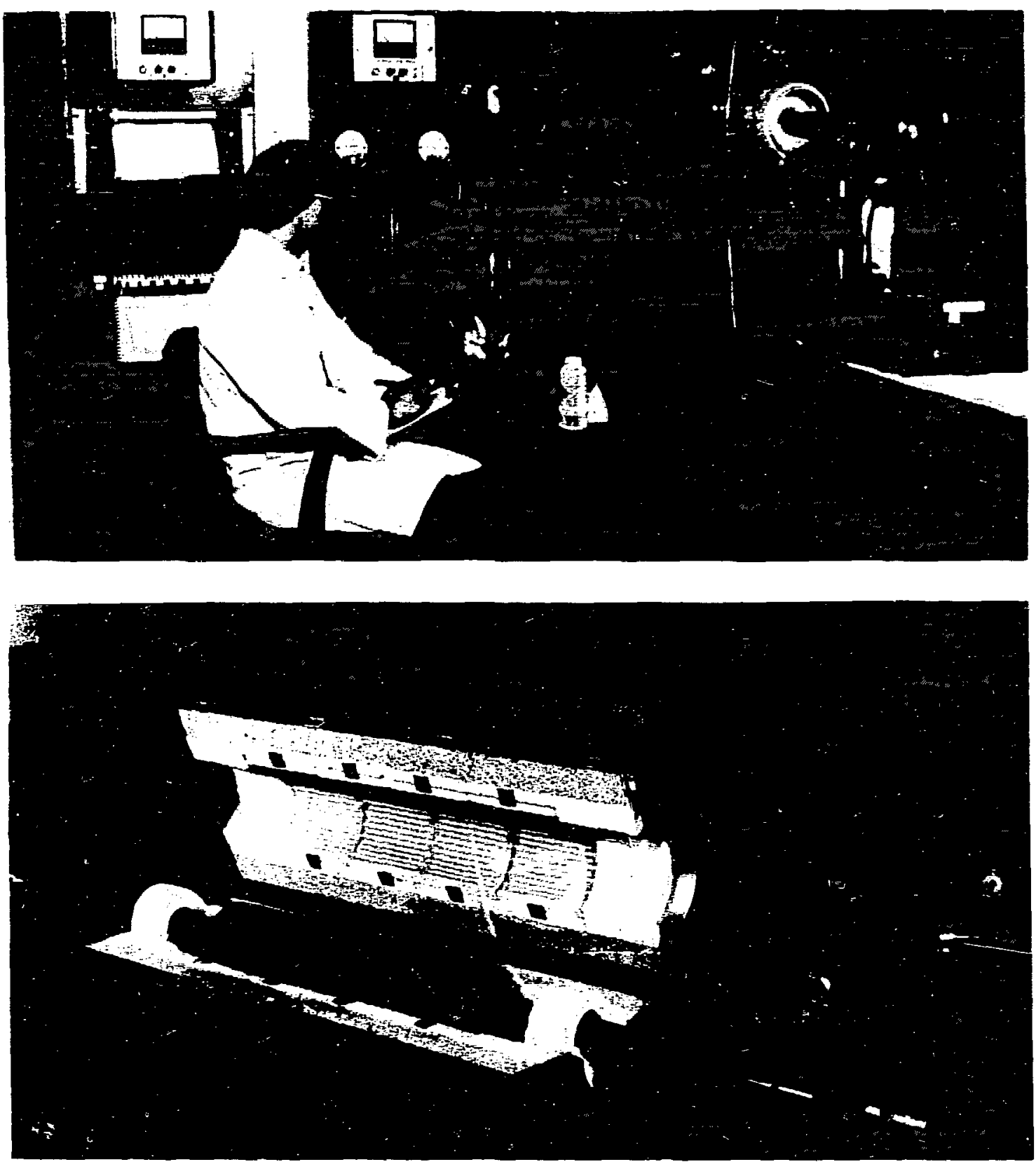

Figure 5. Rotary kiln-type furnace system used to redox calcine air-calcined powders. The reaction vessel was heated in a three-zone split-hinged furnace capable of $1200^{\circ} \mathrm{C}$. 
64 in.
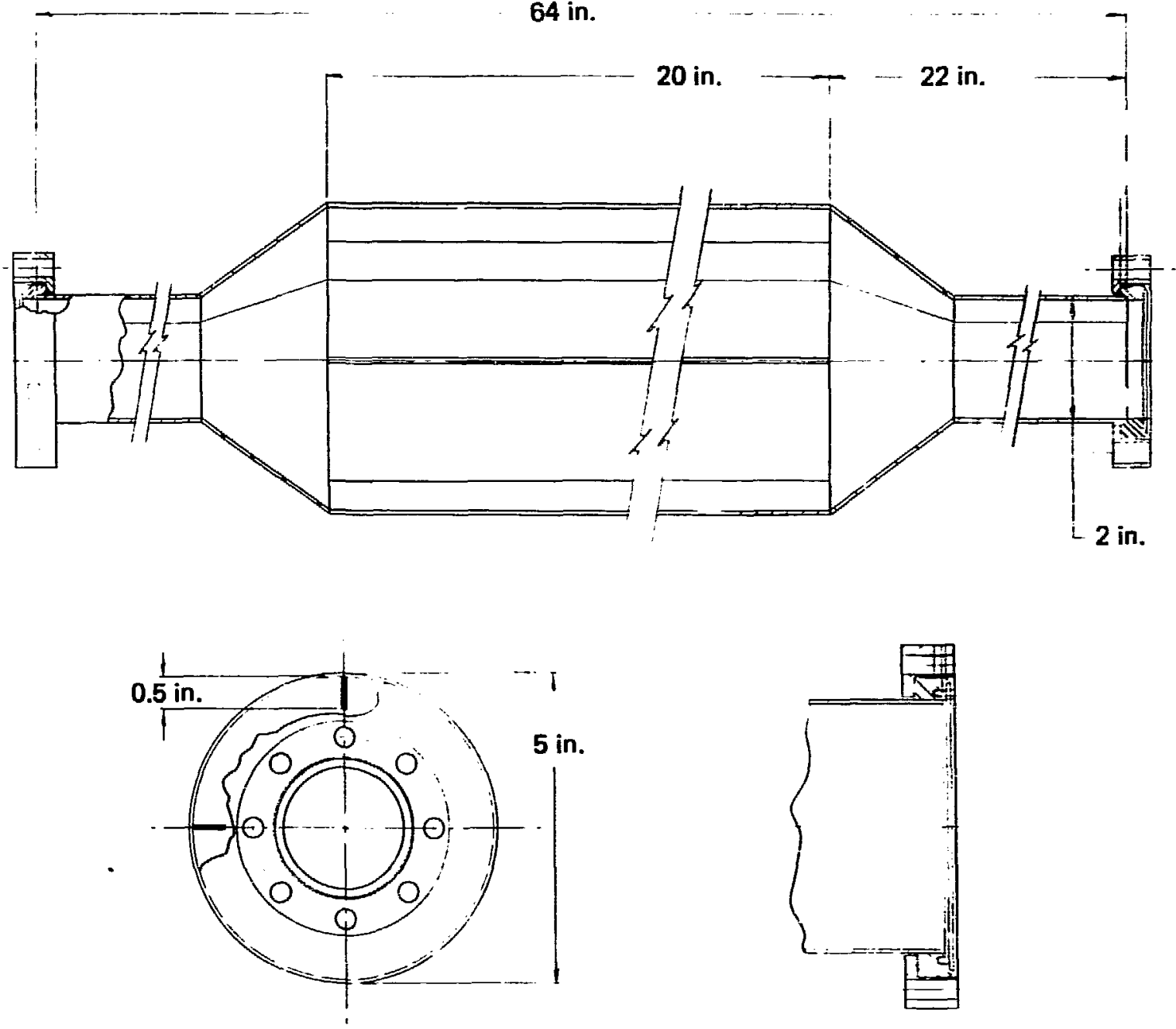

Figure 6. Reaction vessel ( 316 stainless steel) in in ich air-calcined powders were redox calcined. The vessel, filled about one-third full, was rotated in the furnace at about one rpm at $965^{\circ} \mathrm{C}$ for $5-1 f$ hours wilile a carbon dioxide-carbon monoxide $(10: 1)$ reducing atmosphere flowed through it at flow rates of about $461 / \mathrm{h}$ (AAA81-101445-00).

we were concerned about the formation of ilmenite in our calcined powder, we made small-scale hot pressings of this powder at 1000 and $1050^{\circ} \mathrm{C}$ in graphite at $27.6 \mathrm{MPa}(4 \mathrm{ksi})$ to evaluate the consequences of ilmenite in our calcined powder.

$X$-ray analysis of these hot-pressed samples showed goa' Synroc phase formation and no ilmenite. Leach-screening tests also indicated no adverse behavior. However, microstructural analysis indicated some free $\mathrm{ZrO}_{2}$ as a 
minor phase. X-ray analysis did not show free $\mathrm{ZrO}_{2}$. We elected to grind S2l powder in a Sweco Vibro-Energy mill (Model M18L, Sweco Inc., Los Angeles, CA). Powders were milled with alumina balls in isopropyl alcohol for $46 \mathrm{~h}$. Weighing the alumina balls before and after milling indicated no loss of alumina. Additional hot pressings were made of this milled powder, and misrostructural analysis indicated that all the $2 \mathrm{rO}_{2}$ had been incorporated into zirconolite. We did not find it necessary to grind any of the remaining CLT powder batches. Additionally, the redox-calcination temperature for all remaining waste-form powders was reduced from 965 to $800^{\circ} \mathrm{C}$, eliminating ilmenite formation.

After the S21 powders were ground, they were blended a second time. During blending, the powders naturally granulated into free-flowing spheroidal shapes 0.5-1.5 min diam (Fig 7a). This same powder when dispersed

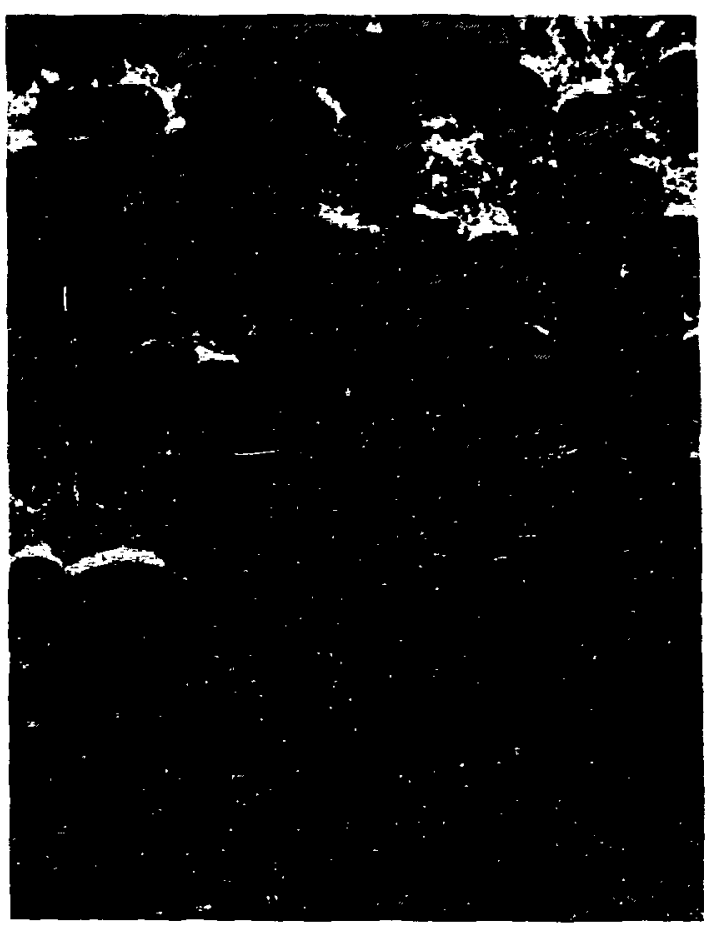

(a) $\underset{0.8 \mathrm{~mm}}{L}$

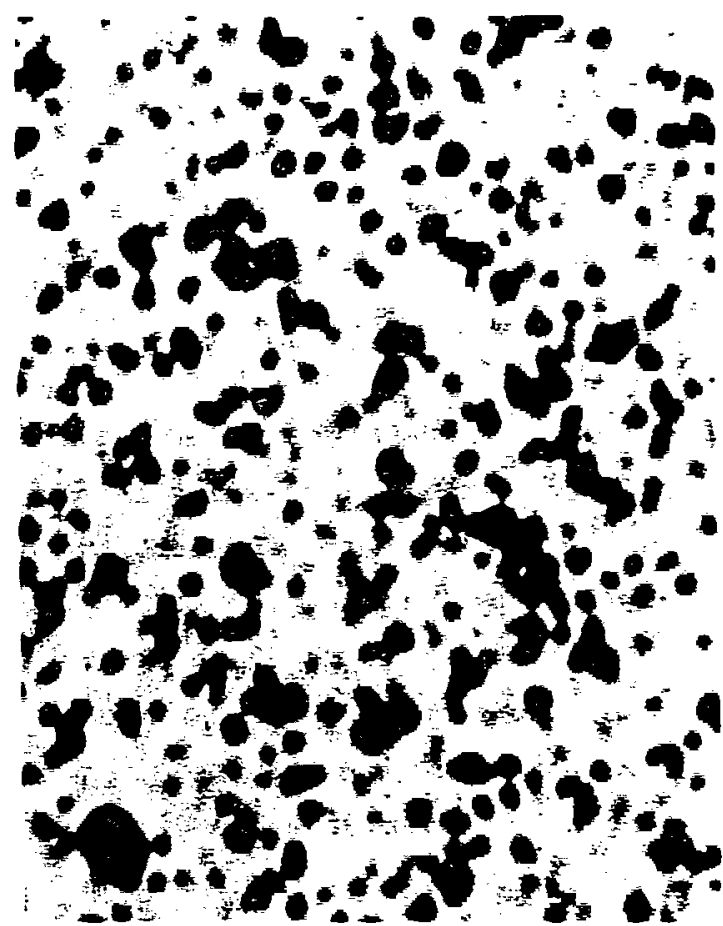

(b) $\underset{0.6 \mu \mathrm{m}}{L}$

Figure 7. The S21 powders (a) after grinding, blending a second time, and granulation into free-flowing spneroidal particles $0.5-1.5 \mathrm{~mm}$ in diam and (b) after ultrasonic dispersion in a liquid medium. 
ultrasonically in a liquid medium is shown in Fig. 7b. We cannot tell in Fig. 7b if all agglomerates have been dispersed, but we can say that all particles are less than $1 \mu m$ in diam. The 521 powder density measured by helium pycnometry was $4.07 \mathrm{~g} / \mathrm{cm}^{3}$. The $\$ 21$ powder surface area, determined by nitrogen gas adsorption (BET), was $7.59 \mathrm{~m}^{2} / \mathrm{g}$. This powder was now ready to be blended with our crushed $\mathrm{S} 18$ cesium-hollandite waste form to make S2 1-s18.

HOLLANDITE PREPARATION

In preparing hollandite (S18), a base composition of $\mathrm{BaO} \cdot \mathrm{Al}_{2} \mathrm{O}_{3} \cdot 7 \mathrm{TiO}_{2}$ having a BaO/Cs $\mathrm{s}_{2} \mathrm{O}$ mol ratio of $9 / 1$ was mixed as an aqueous slurry of $\mathrm{TiO}_{2}$ (pigment-grade anatase), barium and aluminum hydroxides, and cesium nitrate. This slurry was spray dried and air calcined at $900^{\circ} \mathrm{C}$ for $15 \mathrm{~h}$. An $x$-ray analysis indicated hollandite and anatase. The surface area of the calcined powders by nitzogren BET was $8.29 \mathrm{~m}^{2} / 8$. An earlier study ${ }^{27}$ of hollandite preparations of this kind showed no cesium loss during air calcination. This was later confirmed by an analysis of hot-pressed material. Initially, a small amount of powder (S18-HP1A) was hot pressed in graphite at $1200^{\circ} \mathrm{C}$ for $2 \mathrm{~h}$ at $27.6 \mathrm{MPa}$ (4 ksi) for screening ach tests.

Screening leach tests were conducted in deionized water at $150^{\circ} \mathrm{C}$ for 1,2 and 3 days on crushed aggregate $(-48$ to +100 mesh, 300-150 $\mu \mathrm{m})$. They showed cesium losses of $2.2,1.5$, and $1.1 \%$ for each successive day. In an effort to improve the cesium laach behavior, the air-calcined powder was milled a second time in isopropyl alcohol for $71 \mathrm{~h}$. The additional grinding increased the surface area from 8.29 to $12.48 \mathrm{~m}^{2} / \mathrm{g}$. A second small hot pressing (S18-HP2A) was completed in graphite at $1200^{\circ} \mathrm{C}$ for $2 \mathrm{~h}$ at $27.6 \mathrm{MPa}$ (4 ksi). The finer particle size resulted in a higher pressed density that was $99.0 \%$ of theoretical. However, the leaching behavior of this materiai was not improved.

The balance of $\mathrm{S} 18$ powder (about $400 \mathrm{~g}$ ) was then hot pressed in preparation for the S21-S18 formulation. This larger sample (S18-HP3A) was inductively hot pressed in graphite at $1200^{\circ} \mathrm{C}$ for $2 \mathrm{~h}$ at $20.7 \mathrm{MPa}$ (3 ksi).

The sample was then crushed to -16 to +35 mesh $(0.4$ to $1.0 \mathrm{~nm})$ and submitted for characterization. Figure 8 shows crushed S18-HP3A hollandite. The helium pycnometric density of the aggregate was $4.23 \mathrm{~g} / \mathrm{cm}^{3}$. The surface area was $0.042 \mathrm{~m}^{2} / \mathrm{g}$. About $160 \mathrm{~g}$ of hollandite aggregate containing 3.3 wt\% 


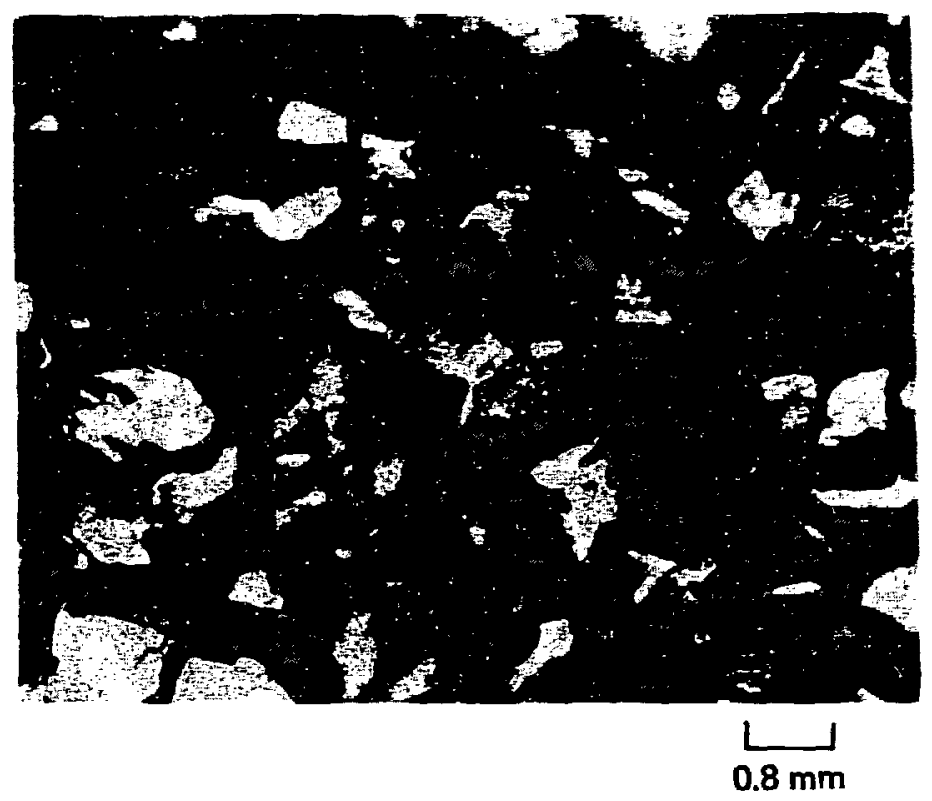

Figure 8. S18-HP3A hollandite crushed to -16 to +35 mesh $(0.4$ to $1.0 \mathrm{~mm})$ particles.

$\mathrm{Cs}_{2} \mathrm{O}$ was cone blended with $2100 \mathrm{~g}$ of $\mathrm{S} 21$ powder to make up the final s21-S18 waste-form composition. This mixture was then uniformly blended for $1 \mathrm{~h}$ before hot pressing. We selected a temperature of $1050^{\circ} \mathrm{C}$ for the hot pressing of S21-S18 because of our concern that higher temperatures would cause extensive hollandite-S21 matrix interactions that could have detrimental effects on leaching. Ryerson ${ }^{28}$ studied the hollandite-Synroc $\mathfrak{D}$ boundary in samples hot pressed in graphite at $1050^{\circ} \mathrm{C}$ for $1 \mathrm{~h}$ at $2 \mathrm{ksi}$. He identified a minor 1-2 $\mu \mathrm{m}$ reaction layer of ilmenite. No radwaste elements were found in this boundary, and it did not affect the leach resistance of S21-s18.

\section{HOT PRESSING}

Small test samples (about $10 \mathrm{~g}$ ) were densified with a resistance-heated hot press (Fig. 9). In this system, electrical currents are passed directly through the insulated graphite pressing die. A calibrated thermocouple $(\mathrm{Pt} / \mathrm{Pt}+10 \% \mathrm{Rh})$ was placed in a tight-fitting hole next to the sample. The thermocouple hole was not drilled through the graphite wall. Gold point calibrations were made at the melting point $\left(1063^{\circ} \mathrm{C}\right)$ and were accurate to $\pm 10^{\circ} \mathrm{C}$. The approximate power to reach temperatures of 1100 to $1200^{\circ} \mathrm{C}$ was $8.1 \mathrm{~kW}$ at $4.5 \mathrm{~V}$ and $1800 \mathrm{~A}$. 


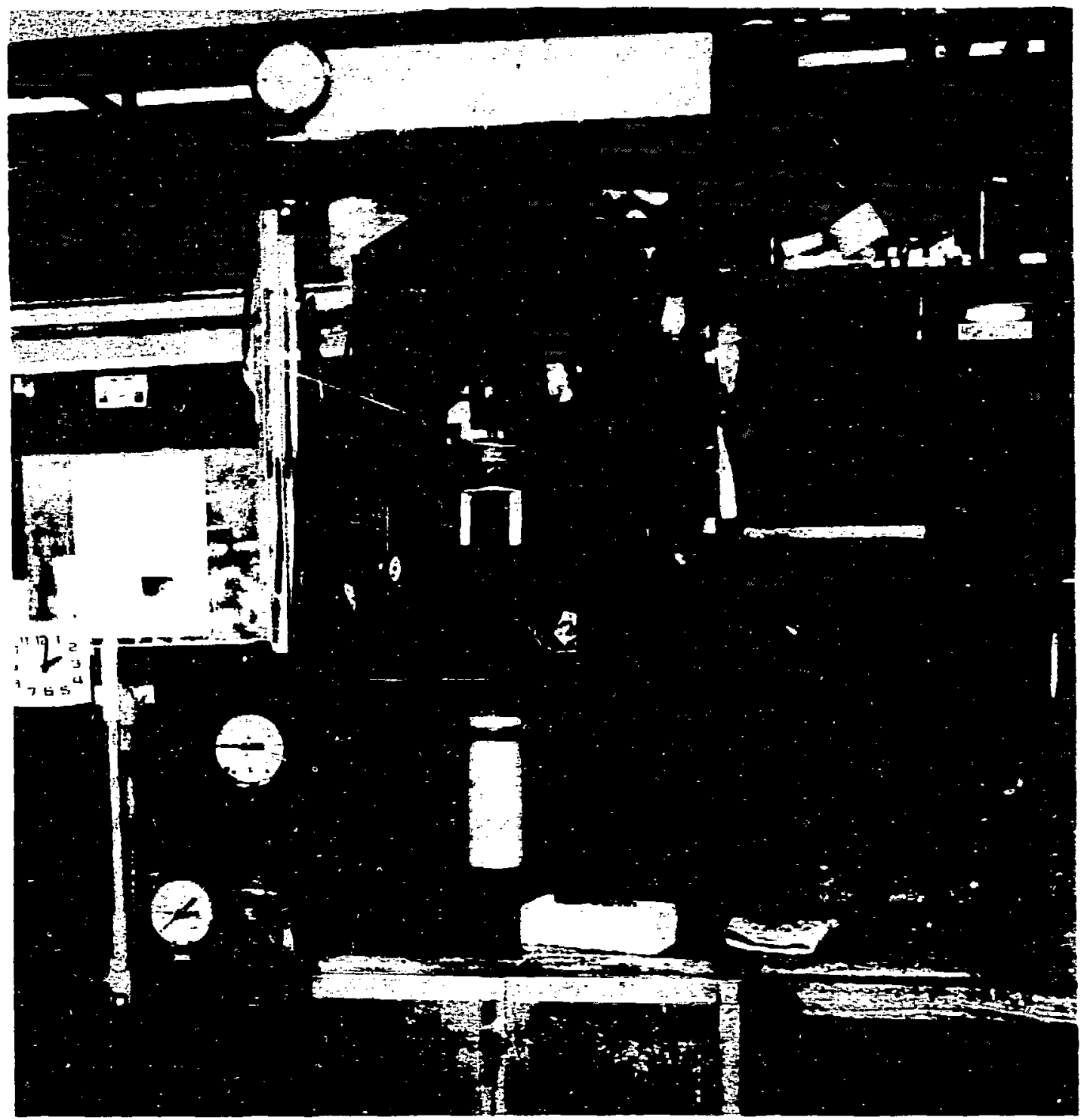

Figure 9. Resistance-heated hot press used to densify small test samples of about $10 \mathrm{~g}$.

Figure 10 shows the graphite die punches and metal capsule inserts. Metal capsules were used in some experiments where closely controlled redox conditions were needed. This was not the case for Synroc $D$ that had been redox calcined. Figure 10 also shows coatings of $\mathrm{Y}_{2} \mathrm{O}_{3}$ made on the inside die wall and on one metal capsule to prevent metal-graphite reactions at higher temperatures. We found this necessary only when nickel capsules were 

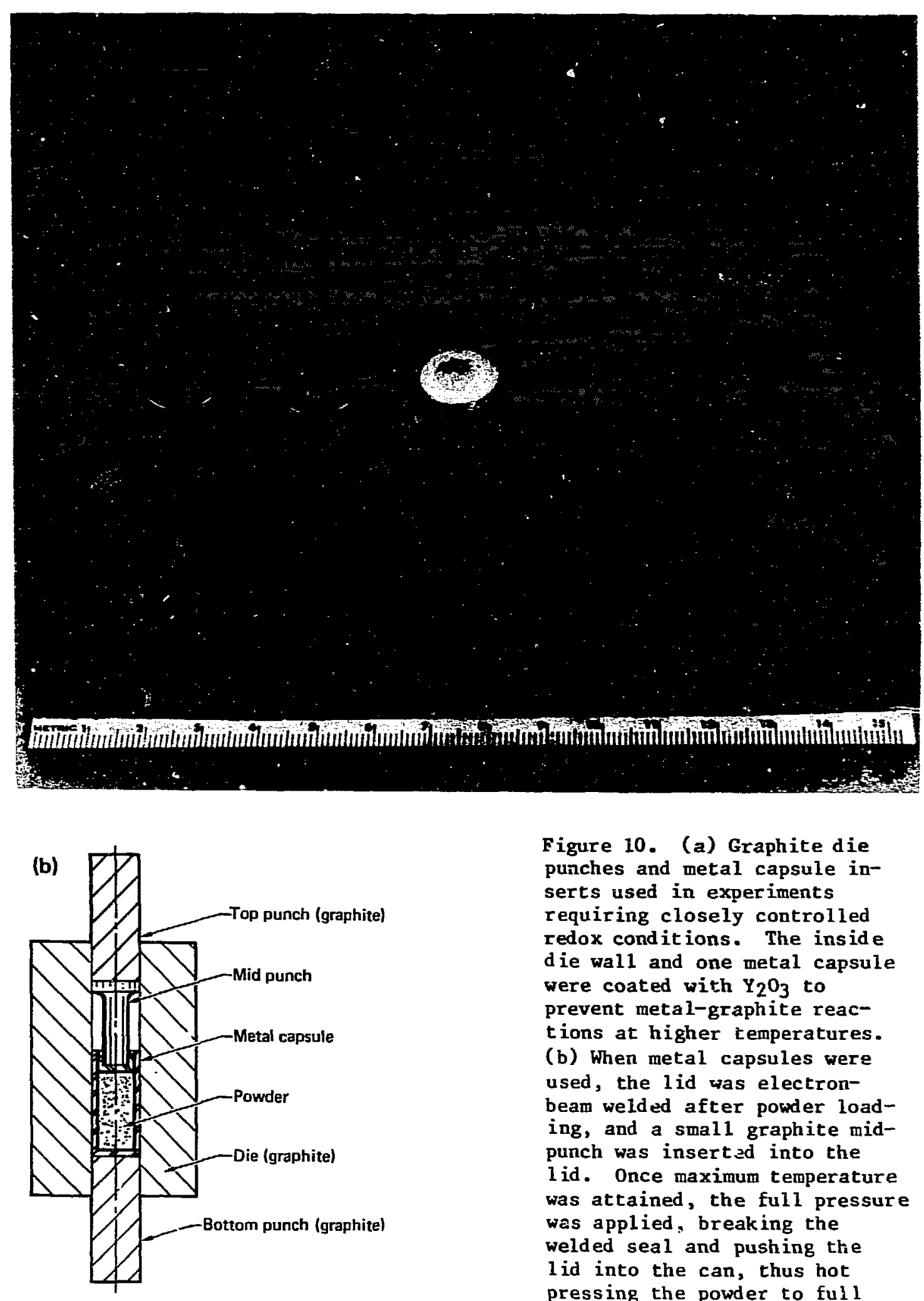

Figure 10. (a) Graphite die punches and metal capsule inserts used in experiments requiring closely controlled redox conditions. The inside die wall and one metal capsule were coated with $\mathrm{Y}_{2} \mathrm{O}_{3}$ to prevent metal-graphite reactions at higher temperatures. (b) When metal capsules were used, the lid was electronbeam welded after powder loading, and a small graphite midpunch was insertad into the 1id. Once maximum temperature was attained, the full pressure was applied, breaking the welded seal and pushing the 1 id into the can, thus hot pressing the powder to full density. 
heated to more than $1300^{\circ} \mathrm{C}$ in graphite. When metal capsules were used, the 1 id was electrol-icem welded after powder loading. Then a small graphite mid-punch shown at the center of Fig. $10 \mathrm{a}$ was inserted into the $1 \mathrm{id}$. The mid-punch was designed to apply pressure only on the lid and not the can wall. After maximum temperature was attained, the full fressure was applied, breaking the welded seal and pushing the lid into the can, which hot pressed the powder to full dersity.

Most of the CLT samples were densified in an induction hot press (Fig. 11). A 7.62-murdiam die was coated with $\mathrm{Y}_{2} \mathrm{O}_{3}$ before loading the powder as a precaution to prevent sample-die reactions. Figure 12 shows a

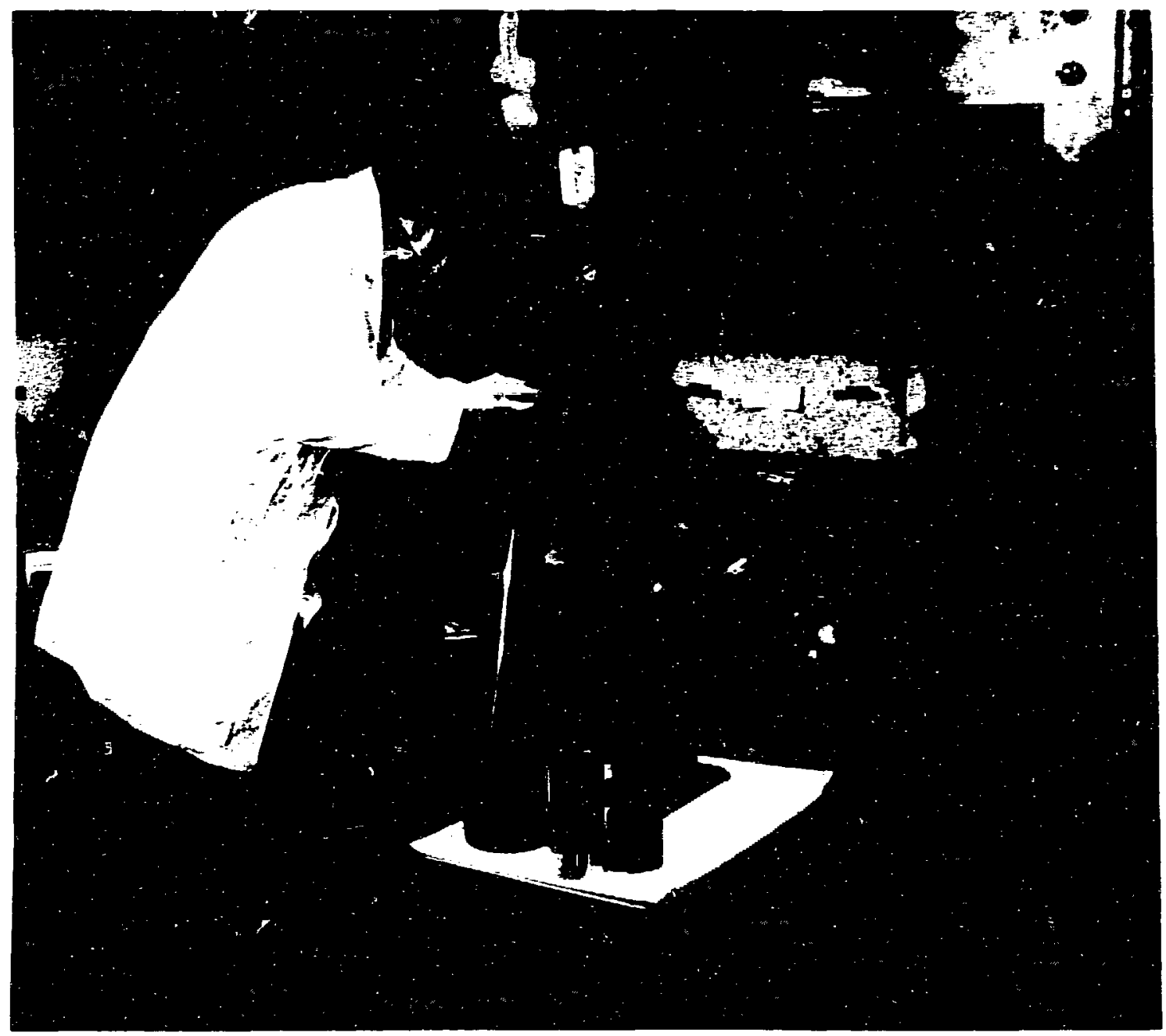

Figure 11. Induction hot press used to densify CLT samples. 

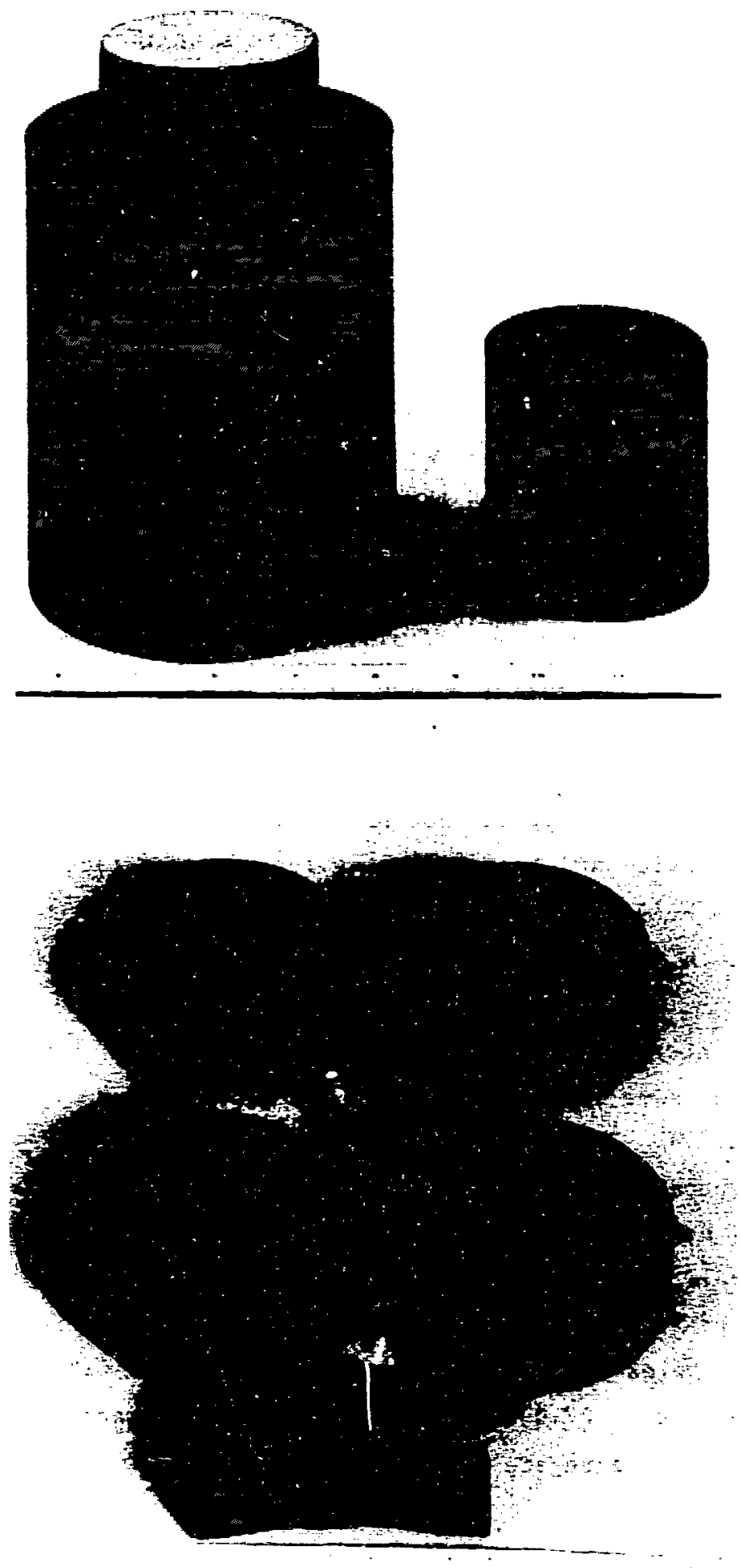

Figure 12. Typical CLT sample after removal from the die; the $\mathrm{Y}_{2} \mathrm{O}_{3}$ coating is still visible. A calibrated optical pyrometer was inserted in the black-body hole in the die to measure the temperature.

Figure 13. Five samples of S2l-S18 composite waste after hot pressing. Four cylinders are show with core drillings removed; these core drillings were used for leach testing and characterization. 
typical CLT sample after removal from the die. The $\mathrm{Y}_{2} \mathrm{O}_{3}$ coating was still visible and was easily removed from the surface by brushing. Also show in Fig. 12 is the blaci hody hole for temperature measurement with a calibrated optical pyrometer.

Five samples of $\mathrm{S} 21-\mathrm{S} 18$ composite waste were hot pressed and sent to SRL for testing (Fig. 13). The weights and immersion densities of each sample are given in Append $i x B$. In Fig. 13, two samples have a small amount of $\mathrm{Y}_{2} \mathrm{O}_{3}$ coating remaining that was not brushed off. Four cylinders are shown with core drillings removed; these core drillings were used for leach testing and characterization at LLNL.

All S2 1-S18 composite samples were hot pressed in graphite dies at $1055^{\circ} \mathrm{C}$ for $1 \mathrm{~h}$ at $13.8 \mathrm{MPa}(2 \mathrm{ksi})$. This temperature is well below $1180^{\circ} \mathrm{C}$, where a major phase change (as determined by differential thermal analysis) occurs in the composite composition. All hot-pressed samples achieved densities (measured by immersion) greater than $3.93 \mathrm{~g} / \mathrm{cm}^{3}$. Mercury porosimetry showed a total open porosity of $0.2 \%$ down to a pore size of $0.0146 \mu \mathrm{m}$ and a maximum pressure density of $3.953 \mathrm{~g} / \mathrm{cm}^{3}$. On this basis, we assign $4.0 \mathrm{~g} / \mathrm{cm}^{3}$ as the theoretical density of S21-S18, and all CLT samples were $>98 \%$ of theoretical.

Table 14 gives a complete account of typical hot-pressing parameters for S21-S18-HP8A, and Fig. 14 plots density and temperature as functions of $t$ ime.

In addition, S21-S18 samples HP10A, HP1LA, and HP12A were annealed at $800^{\circ} \mathrm{C}$ for $30 \mathrm{~min}$ during cooling. All sampies lost about $1.3 \%$ of their weight during hot pressing.

The data plotted in Fig. 14 are typical for waste-form compositions covered in this report except that some compositions were hot pressed at a slightly higher temperature $\left(1100^{\circ} \mathrm{C}\right)$. The data show that no significant densification occurred until temperatures of about $900^{\circ} \mathrm{C}$ vere reached. If full pressure [13.8 MPa (2 ksi)] had been applied at the onset, the threshold temperature for densification would have been lower. These data compare very well with results reported earlier for composite synroc D. 20 In that work, density-vs-time plots for small samples $(10 \mathrm{~g})$ of Synroc D without hollandite addition were given at three pressures: $27.6,13.8$, and $6.9 \mathrm{MPa}(4,2$, and $1 \mathrm{ksi}$, respectively). The hollandite aggregate additions had little effect on the hot-pressing behavior.

Samples were taken from both edge and center positions on one CLT sample (S21-S18-HP8A) for $x$-ray and microstructural analysis. We could find no 
Table 14. Hot-pressing parameters for Synroc D composite S21-S18-HP8A.a,b

\begin{tabular}{|c|c|c|c|}
\hline $\begin{array}{l}\text { Time } \\
(\min )\end{array}$ & $\begin{array}{l}\text { Temperature } \\
\left({ }^{\circ} \mathrm{C}\right)\end{array}$ & $\begin{array}{l}\text { Pressure } \\
\text { (ksi) }\end{array}$ & $\begin{array}{l}\text { Percent theoretical } \\
\text { density }\end{array}$ \\
\hline 0 & 23 & 1 & 47 \\
\hline 51 & 740 & 1 & 47 \\
\hline 65 & 810 & 1 & 47 \\
\hline 85 & 940 & 1 & 47 \\
\hline 95 & 997 & 1 & 52 \\
\hline 106 & $1050^{\circ} \mathrm{C}$ & 2 & 76 \\
\hline 110 & 1054 & 2 & 86 \\
\hline 113 & 1052 & 2 & 89 \\
\hline 116 & 1055 & 2 & 93 \\
\hline 120 & 1055 & 2 & 95 \\
\hline 125 & 1055 & 2 & 97.0 \\
\hline 130 & 1055 & 2 & 97.5 \\
\hline 140 & 1055 & 2 & 98.0 \\
\hline 155 & 1056 & 2 & 98.5 \\
\hline 167 & $1050^{d}$ & 0 & 98.5 \\
\hline 170 & 1004 & 0 & \\
\hline 175 & 950 & 0 & \\
\hline 180 & 895 & 0 & \\
\hline 185 & 850 & 0 & \\
\hline 190 & $820 \mathrm{e}$ & 0 & \\
\hline
\end{tabular}

a The sample was hot pressed in a $7.62-c m-d i a m$ graphite die under a flowing argon atmosphere.

b All S21-S18 hot pressings ( $8 \mathrm{~A}, 9 \mathrm{~A}, 10 \mathrm{~A}, 11 \mathrm{~A}$ and 12A) were hot pressed under similar conditions except that $10 \mathrm{~A}, 1 \mathrm{AA}$, and $12 \mathrm{~A}$ were annealed for 30 min at $800^{\circ} \mathrm{C}$ during cooling.

c Begin l-h hold at maximum pressure.

d End 1-h hold; power turned off and pressure released.

e Overnight cooling to room temperature.

significant compositional differences between these locations. Figure 15 shows $x$-ray patterns of samples from both positions. As indicated, all peaks in a $2 \theta$ span of 10 to 74 have been identified except for a few small peaks. In addition, the edge-section $x$-ray pattern shows the presence of a metallic iron alloy, which indicates that more graphite reduction does occur in the outer regions of the sample. We did not find any difference in the leaching behavior of samples taken from both locations.

The microstructurai characterization of this waste form is discussed in an earlier report. 28 Table 13 shows the results of chemical analysis of a sample of ground hot-pressed material. We did not determine the $\mathrm{Fe}^{+2} / \mathrm{Fe}^{+3}$ ratio of the hot-pressed materials. 


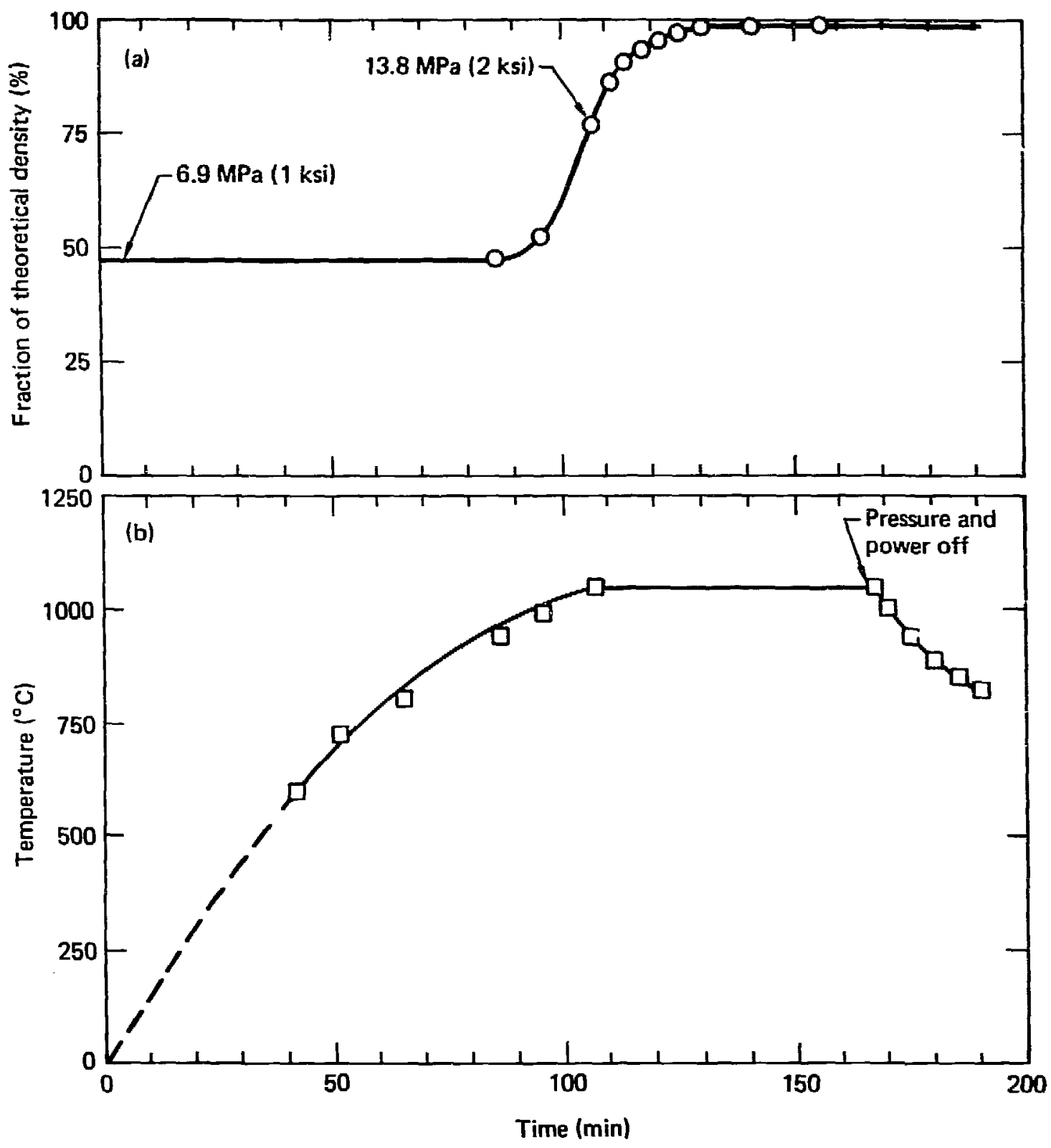

Eigure 14. Hot pressing data for Synroc D composite (S21-S18-HP8A). Densification (a) and temperature (b) as functions of $t$ ime at an initial pressure of $6.9 \mathrm{MPa}(1 \mathrm{ksi})$ and a final pressure of $13.8 \mathrm{MPa}$ (2 ksi). 


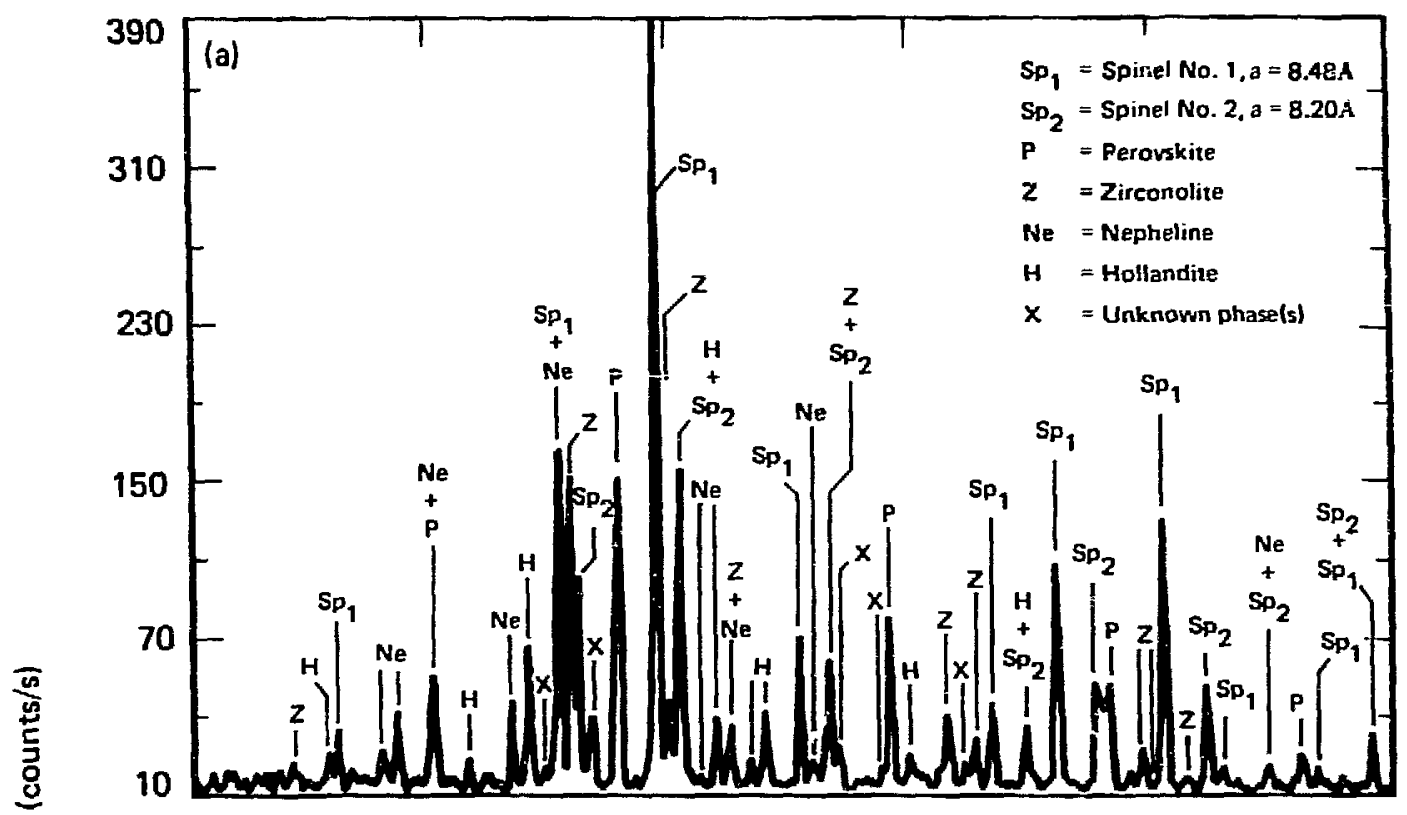

壱

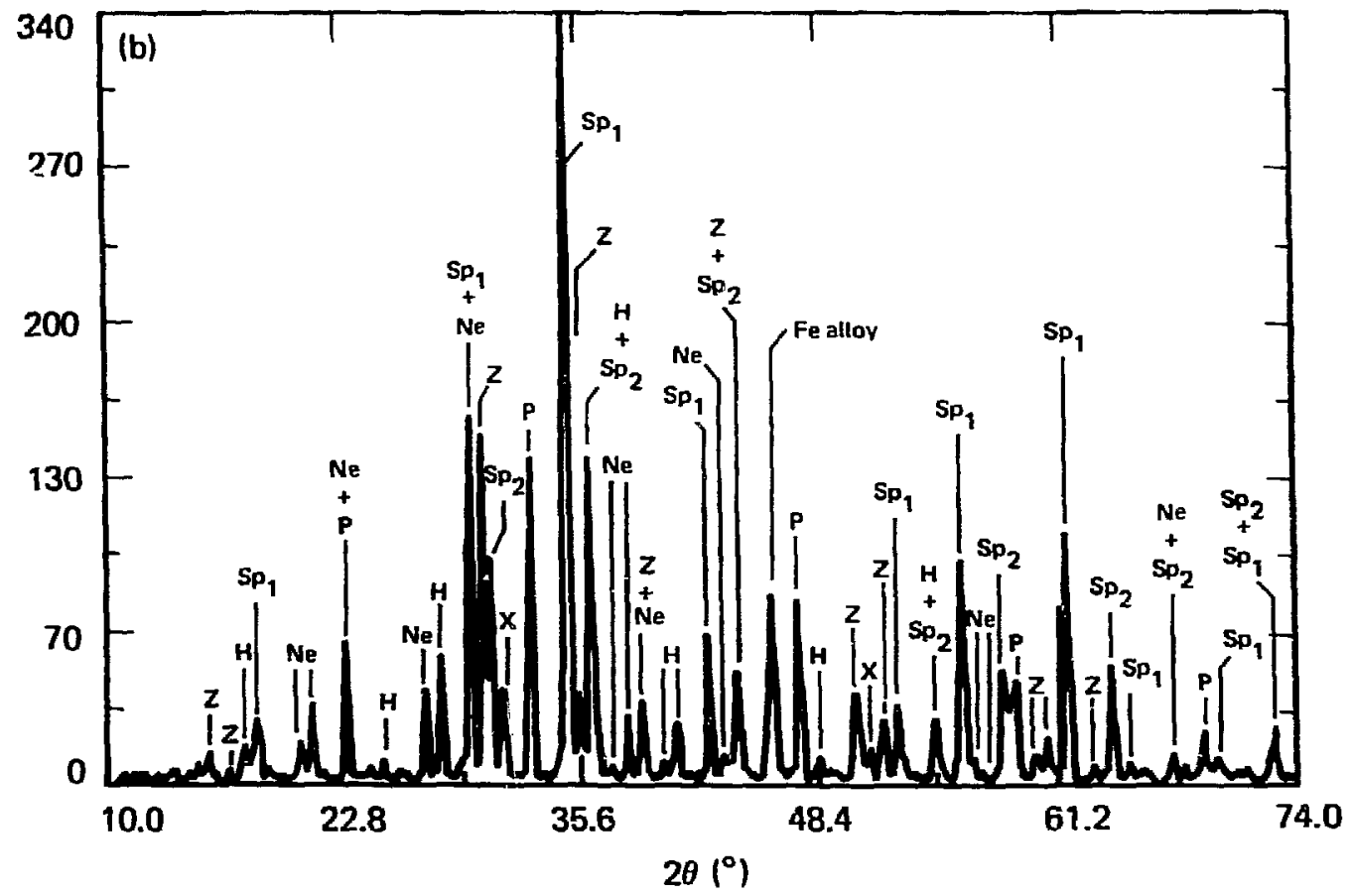

Figure 15. X-ray patterns of a CLT sample (S21-S18-HP8A) taken from (a) center and (b) edge locations. Except for a few small peaks, all peaks in the $2 \theta$ span of 10 to 74 were identified, and we found no significant compositional differences between these locations. 
Just before preparing samples for CLT using SRL sludges, we formulated a larger batch of Synroc D composite called S20-\$03a. This was done both as a final preparation step for the CLT program and also to prepare larger samples for mechanica1- and thermophysical-properties studies.

For S20-503a, we used a simulated sludge supplied by Southwestern Analytical Chemical, Inc. A composite composition equivalent to about $3.5 \mathrm{~kg}$ of oxide was made up in three slurry batches, spray dried, and air calcined at $650^{\circ} \mathrm{C}$ to constant weight. The powders were then redox calcined in 0.7-to-1.0-kg batches at 800 to $915^{\circ} \mathrm{C}$ and analyzed for iron oxidation state. Powder batches were then blended before adding crushed hollandite (\$03a, -16 to +35 mesh) and hot pressing.

Two smaller 3-in.-diam hot pressings (S20-S03a-HP1A and S20-S03-HP2A) were prepared for the impact studies at Argonne National Laboratory (Appendix B). A larger 6-in.-diam hot pressing (S20-S03a-AP4A) was also prepared for mechanical-property studies at LLNL. Figure 16 shows the hot press and gives the time-temperature history of this sample. Figure 17 shows the sample after hot pressing; about $1.6 \mathrm{~kg}$ powder with hollandite was hot pressed in a 6-in.-diam graphite die at $1050^{\circ} \mathrm{C}$ in vacuum at $13.8 \mathrm{MPa}$ (2 ksi) for $1 \mathrm{~h}$. Temperatures were measured both optically and with a thermocouple. A calibrated optical pyrometer was manually sighted into a black-body hole drilled into the die wall. A sheathed thermocouple was positioned so that it touched the outer surface of the graphite die. After hot pressing, the large disk was cut with a diamond saw and cores were drilled into smaller test specimens to measure flexural and compressive strengths, ultrasonic elastic constants, thermal expansion, and thermal conductivity. Figure 18 shows some of these test samples.

\section{MECHANICAL AND THERMOPHYSICAL PROPERTIES}

The general test procedures for this property study of Synroc $D$ were described in an earlier report ${ }^{29}$ in which we evaluated Synroc B in a similar manner.

\section{ULTRASONIC ELASTIC CONSTANTS}

Water-immersion densities and ultrasonic elastic constants were measured on four samples (Fig. 18a) taken from separate regions of the large 

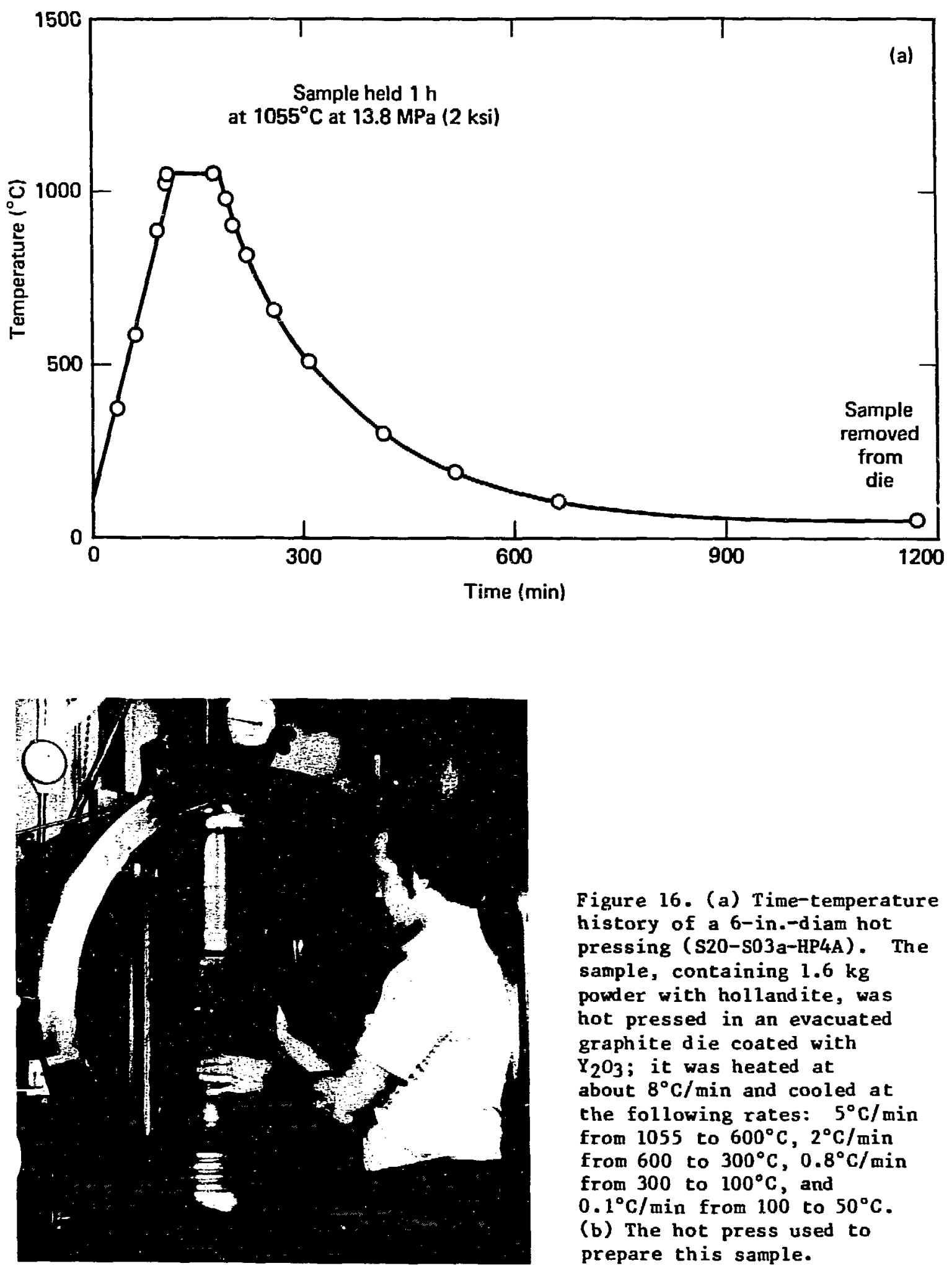

Figure 16. (a) Time-temperature history of a 6-in.-diam hot pressing (S20-S03a-HP4A). The sample, containing $1.6 \mathrm{~kg}$ powder with hollandite, was hot pressed in an evacuated graphite die coated with $\mathrm{Y}_{2} \mathrm{O}_{3}$; it was heated at about $8^{\circ} \mathrm{C} / \mathrm{min}$ and cooled at the following rates: $5^{\circ} \mathrm{c} / \mathrm{min}$ from 1055 to $600^{\circ} \mathrm{C}, 2^{\circ} \mathrm{C} / \mathrm{min}$ from 600 to $300^{\circ} \mathrm{C}, 0.8^{\circ} \mathrm{C} / \mathrm{min}$ from 300 to $100^{\circ} \mathrm{C}$, and $0.1^{\circ} \mathrm{C} / \mathrm{min}$ from 100 to $50^{\circ} \mathrm{C}$. (b) The hot press used to prepare this sample. 
Figure 17. The sample after hot pressing.

Figure 18. Smaller test specimens cut from the disk and cores. (a) Samples on which water-imersion densities and ultrasonic elastic constants were measured. (b) Samples cut for flexural-strength testing. (c) Samples cut for linear thermal expansion studies. (d) Samples prepared for compressive testing.

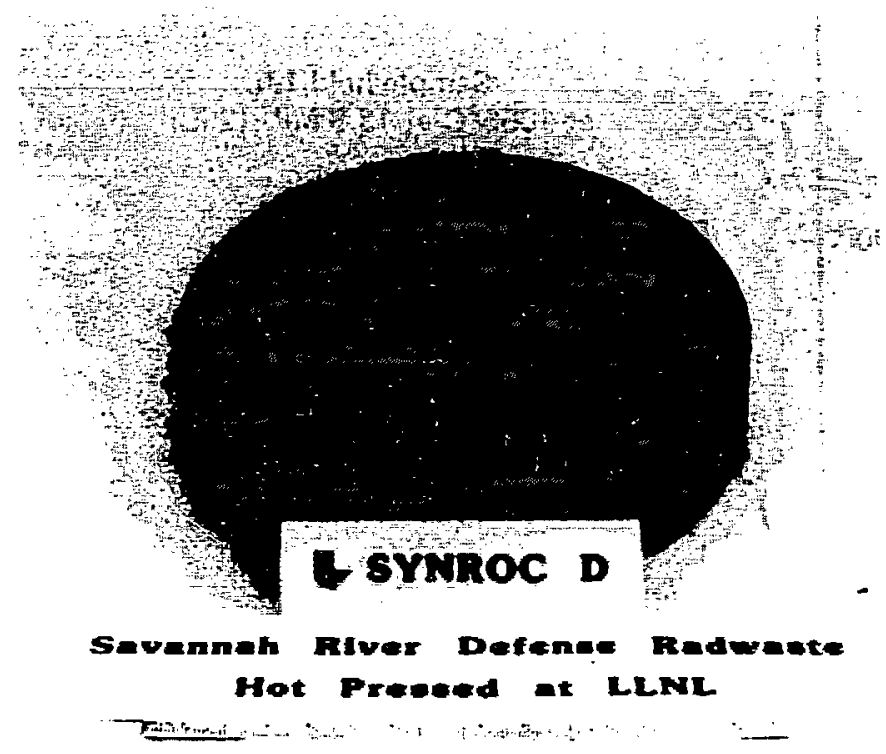

(d)

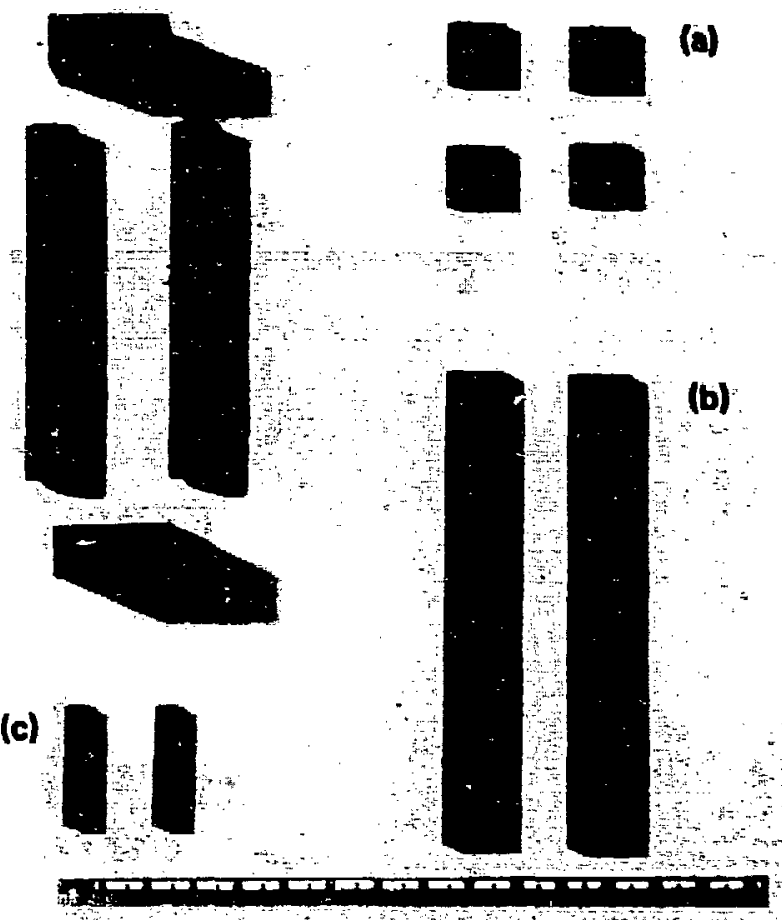


hot-pressed sample. These samples (E-1 to $E-4)$ were $1 / 2$ in square and $0.150 \mathrm{in}$. thick, and the large faces were ground flat and parallel to $<0.0005$ in. deviation across the flat surfaces. Table 15 1ists the results of these measurements. The mean density of $4.00 \pm 0.01 \mathrm{~g} / \mathrm{cm}^{3}$ indicates good density homogeneity throughout the sample. Ultrasonic measurements were made at $20 \mathrm{MHz}$ (longitudinal) and $10 \mathrm{MHz}$ (shear). The mean values and eirors calculated as the standard deviation from the mean also indicated good homogeneity across the sample in regard to elastic properties. The average Young's Modulus of $138.93 \mathrm{GPa}$ compares well with an average ferrite body ${ }^{30}$ having a modulus of about $140 \mathrm{GPa}\left(P=4.7 \mathrm{~g} / \mathrm{cm}^{3}, n 7 \%\right.$ porosity).

ELEXURAL STRENGTH

Figure 18b shows two of the four samples cut for flexural-strength testing. Sample dimensions were nominally 4.00 by 0.50 by 0.19 in., and tests were conducted in four-point bending with a 3-in. span. After samples were tested with a 3-in. span, four broken segments were tested a second time with a 1.5-in. span. Resuits of 3-in.-span testing are available for only two of the four specimens because of equipment malfunctions. Only the data for

Table 15. Immersion density and ultrasonic elastic constants of Synroc D composite (S20-S03a-HP4A)

\begin{tabular}{|c|c|c|c|c|c|c|c|c|}
\hline $\begin{array}{l}\text { Samr } \\
\text { ple } \\
\text { No. }\end{array}$ & $\begin{array}{l}\text { Thick- } \\
\text { ness } \\
\text { (mm) }\end{array}$ & $\begin{array}{l}\text { Density } \\
\left(\mathrm{g} / \mathrm{cm}^{3}\right)\end{array}$ & $\begin{array}{l}\text { Longi- } \\
\text { tudinal } \\
\text { velocity } \\
(\mathrm{m} / \mathrm{s})\end{array}$ & $\begin{array}{l}\text { Shear } \\
\text { velocity } \\
(\mathrm{m} / \mathrm{s})\end{array}$ & $\begin{array}{l}\text { Poisson's } \\
\text { ratio }\end{array}$ & $\begin{array}{l}\text { Bulk } \\
\text { modulus } \\
\text { (GPa) }\end{array}$ & $\begin{array}{l}\text { Shear } \\
\text { modulus } \\
\text { (GPa) }\end{array}$ & $\begin{array}{l}\text { Young's } \\
\text { modulus } \\
\text { (GPa) }\end{array}$ \\
\hline $\begin{array}{l}E-1 \\
E-2 \\
E-3 \\
E-4\end{array}$ & $\begin{array}{l}3.860 \\
3.870 \\
3.879 \\
3.713\end{array}$ & $\begin{array}{l}3.992 \\
3.998 \\
4.009 \\
4.012\end{array}$ & $\begin{array}{l}6688 \\
6691 \\
6725 \\
6684\end{array}$ & $\begin{array}{l}3683 \\
3676 \\
3677 \\
3667\end{array}$ & $\begin{array}{l}0.282 \\
0.284 \\
0.287 \\
0.285\end{array}$ & $\begin{array}{l}106.4 \\
106.9 \\
109.0 \\
107.3\end{array}$ & $\begin{array}{l}54.14 \\
54.03 \\
54.21 \\
53.96\end{array}$ & $\begin{array}{l}138.86 \\
138.72 \\
139.50 \\
138.63\end{array}$ \\
\hline $\begin{array}{l}\text { Mean } \\
\text { ob }\end{array}$ & value & $\begin{array}{r}4.00 \\
+0.01\end{array}$ & $\begin{array}{r}6697 \\
+19\end{array}$ & $\begin{array}{r}3676 \\
\pm 7\end{array}$ & $\begin{array}{r}0.285 \\
+0.002\end{array}$ & $\begin{array}{r}107.4 \\
\pm 1.1\end{array}$ & $\begin{array}{r}54.09 \\
+0.11\end{array}$ & $\begin{array}{r}138.93 \\
+0.39\end{array}$ \\
\hline
\end{tabular}

a Longitudinal frequency $=20 \mathrm{MHz}$, shear frequency $=10 \mathrm{Mz}$ (A. E. Brown, Lawrence Livermore National Laboratory, Livermore, CA, Materials Test Engineering Report No. 81-149, March 27, 1981).

b Standard deviation. 
3-in.-span testing meets the required specifications of ASTM $^{31}$. Data were taken over the shorter span only to demonstrate the degree of homogeneous strength throughout the samples (Table 16). The mean strengths were 65 and $55 \mathrm{MPa}(9.4$ and $8.0 \mathrm{ksi})$ for 3-in. and 1.5-in. spans, respectively. Both values fall within the error band of the 1.5-in. span. Accordingly, we averaged all six values to give a mean value of $59 \pm 12 \mathrm{kPa}(8.5 \pm 1.7 \mathrm{ksi})$ for the flexural strength. The values for bulk modulus, however, varied significantly for the two spans. We believe the bulk modulus of 159 MF a $(23,000 \mathrm{ksi})$ for the $3-\mathrm{in}$. span is the more reliable value because samples tested at the shorter $1.5-i n$. span are subjected to relatively high shear forces that are present at the support fixtures.

Table 16. Flexural strength of Synroc D composite ( $20-\mathrm{S} 03 a-H P 4 A) .{ }^{a}$

\begin{tabular}{|c|c|c|c|c|c|c|}
\hline $\begin{array}{l}\text { Sam } \\
\text { ple } \\
\text { No.b }\end{array}$ & $\begin{array}{l}\text { Support } \\
\text { span } \\
\text { (in.) }\end{array}$ & $\begin{array}{l}\text { Width } \\
\text { (in.) }\end{array}$ & $\begin{array}{l}\text { Depth } \\
\text { (in.) }\end{array}$ & $\begin{array}{l}\text { Fracture } \\
\text { load } \\
\text { (1b) }\end{array}$ & $\begin{array}{l}\text { Fracture } \\
\text { stress } \\
\text { (ksi) }\end{array}$ & $\begin{array}{l}\text { Bending } \\
\text { modulus } \\
\left(10^{-3} \mathrm{ksi}\right)\end{array}$ \\
\hline $\begin{array}{l}3 A \\
4 A\end{array}$ & $\begin{array}{l}3.0 \\
3.0\end{array}$ & $\begin{array}{l}0.4002 \\
0.5073\end{array}$ & $\begin{array}{l}0.1882 \\
0.1773\end{array}$ & $\begin{array}{l}45.6 \\
47.6\end{array}$ & $\begin{array}{l}9.7 \\
9.0\end{array}$ & $\begin{array}{l}23.0 \\
23.0\end{array}$ \\
\hline $\begin{array}{l}\text { Mean } \\
\sigma^{c}\end{array}$ & & & & & $\begin{array}{r}9.4 \\
+0.5\end{array}$ & 23.0 \\
\hline $1 A-2$ & 1.5 & 0.4018 & 0.1928 & 65.6 & 6.6 & 14.7 \\
\hline $\begin{array}{l}2 A-2 \\
3 A-2 \\
4 A-2\end{array}$ & $\begin{array}{l}1.5 \\
1.5 \\
1.5\end{array}$ & $\begin{array}{l}0.5080 \\
0.4002 \\
0.5073\end{array}$ & $\begin{array}{l}0.1890 \\
0.1882 \\
0.1773\end{array}$ & $\begin{array}{r}79.2 \\
101.6 \\
85.8\end{array}$ & $\begin{array}{r}6.6 \\
10.8 \\
8.1\end{array}$ & $\begin{array}{l}14.2 \\
16.3 \\
14.3\end{array}$ \\
\hline $\begin{array}{l}\text { Mean } \\
\sigma^{c}\end{array}$ & & & & & $\begin{array}{r}8.0 \\
+2.0\end{array}$ & $\begin{array}{r}14.9 \\
+0.9\end{array}$ \\
\hline
\end{tabular}

a Data taken from R. L. Brady, Lawrence Livermore National Laboratory, Livermore, CA, Materials Test Engineering Report No. 81-183, ET \#6775, May 7, 1981.

b Samples $3 \mathrm{~A}-2$ and $4 \mathrm{~A}-2$ tested using a 1.5-in. support span were taken from broken samples $3 A$ and $4 \mathrm{~A}$.

c standard deviation. 
Figure 18d shows two long core-drilled samples prepared for compressive testing are shown. These two samples were then cut into smaller sizes ( 13.2 min diam by 63.5 m long) according to ASTM test specifications. 32 Also shown in Fig. 18d are rectangular bearing blocks cut from the same material in order to match the elastic moduli at the loading points. Copper was also used as a bearing block in some tests. Table 17 gives the results of these tests. The average compressive strength was $353 \pm 30 \mathrm{MPa}$ $(51.2 \pm 4.3 \mathrm{ksi})$. For comparison, the compressive strengths of porous ferrites $^{27}\left(\mathrm{P}=4.7 \mathrm{~g} / \mathrm{cm}^{3}, 7 \%\right.$ porosity) fall between 400 to $700 \mathrm{MPa}$.

\section{THERMAL EXPANSION}

Figure $18 \mathrm{c}$ shows two samples $(25.4$ by 4.8 by $4.8 \mathrm{~mm}$ ) clit from the same location for linear thermal expansion studies. The equipment and test procedures have been described in an earlier report. 29 Measurements were performed in accordance with ASTM E-228-71 for a Vitreous Silica Dilatometer.

Table 17. Compressive strength of Synroc D composite ( $220-\mathrm{S} 03 a-H P 4 A) .^{a}$

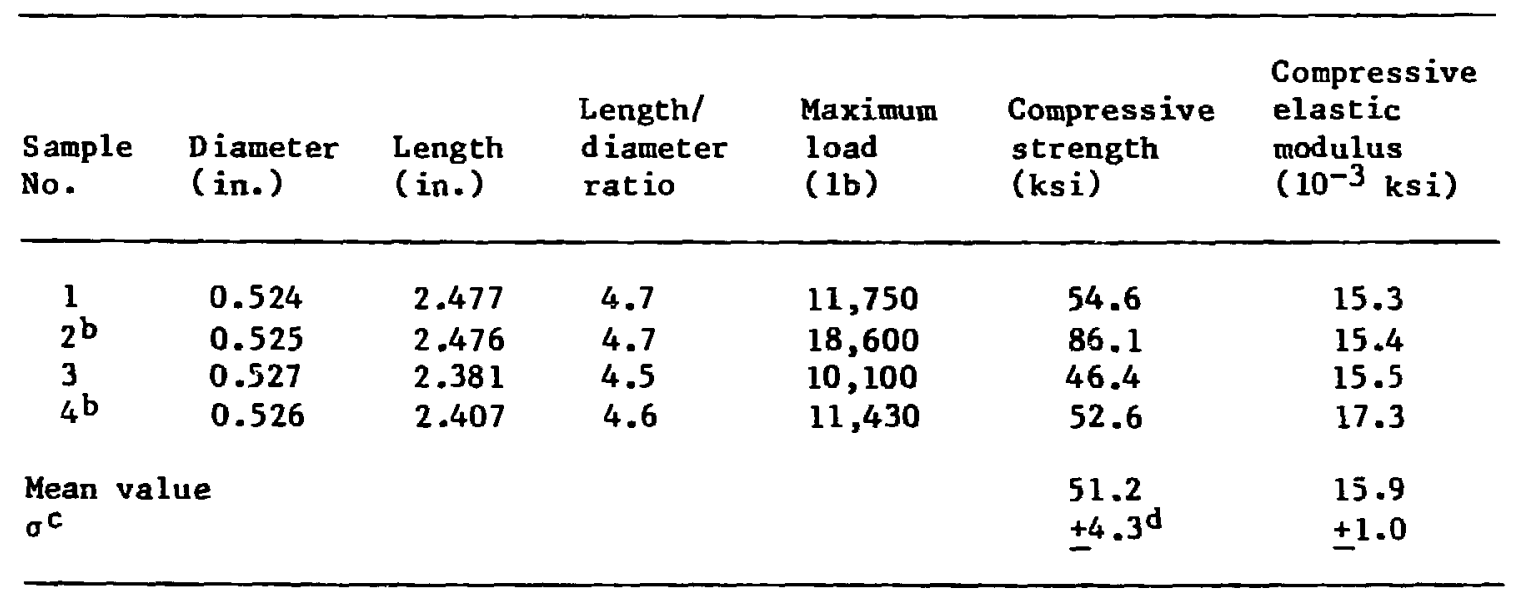

a Data taken from R. L. Brady, Lawrence Livermore National Laboratory, Livermore, CA, Materials Test Engineering Report No.81-183, ET \$6787, May 19 , 1981.

b Copper metal was used as bearing block material instead of Synroc D.

c standard deviation.

d The high value for specimen No. 2 was not included in the average and standard deviation calculations. 
Figure 19 shows one sample heated to $950^{\circ} \mathrm{C}$ that maintained excellent structural integrity after testing; the hollandite inclusions are clearly visible.

Four therma' expansion runs for two samples $(\mathrm{C}-1$ and $\mathrm{c}-2$ ) are plotted in Fig. 20. Thermal expansion coefficients calculated at several temperature intervals are tabulated in Table 18. Overall the expansion coefficients listed in Table 18 fall in the range of coefficients reported for Hnzn ferrites $\left(\alpha=11 \times 10^{-6}, 0-200^{\circ} \mathrm{C}\right)$ and for Nizn ferrites $\left(a=8 \times 10^{-6}, 0-200^{\circ} \mathrm{C}\right) .30$

As snown in Fig. $20 \mathrm{a}$, the first and second runs of sample $\mathrm{C}-1$ (heated to $950^{\circ} \mathrm{C}$ ) differ significantly. The expansion coefficients for all temperature ranges are on the order of $17-25 \%$ higher in the initial test run than in the second test run. This behavior indicates that an annealing effect (relieving internal stresses) took place during the initial run. This same behavior is typical of strained glass where differences as small as $5 \%$ in the thermal expansion coefficients have been measured between strained and annealed soda-lime-silica glasses. ${ }^{33}$ In these tests to $950^{\circ} \mathrm{C}$, the cooling rates vere approximately ten times faster than the original hot-pressed cooling rate shown in Fig. 17. Therefore, some of the internal stress shown in Fig. 20a may have been induced during the rapid cooling after run 1 .

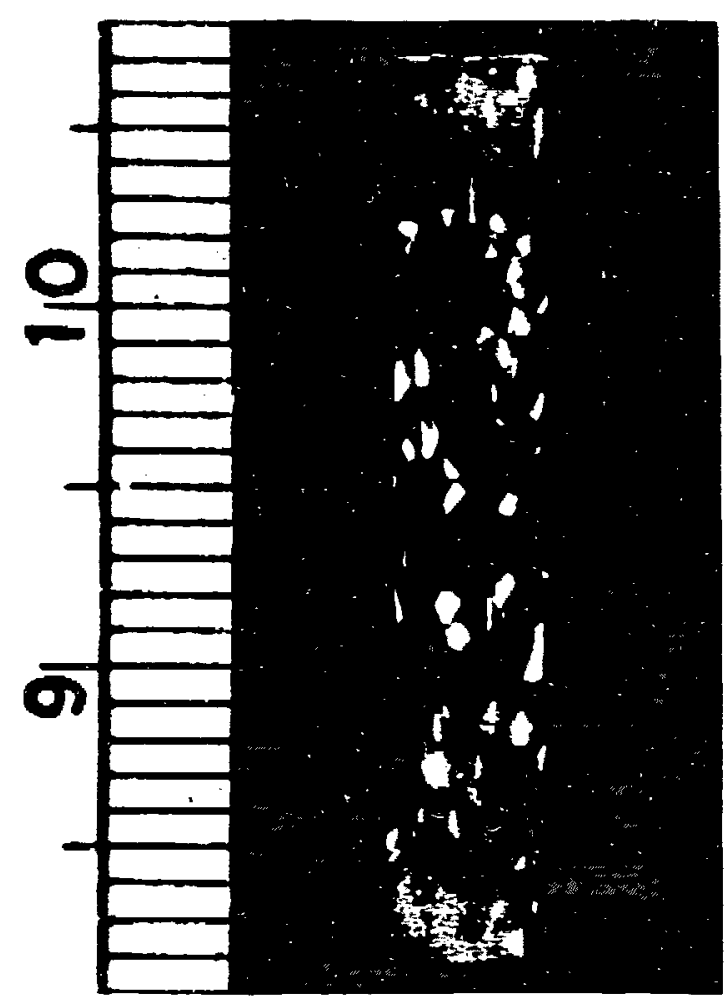

Figure 19. Synroc D compasite ( $220-$ S03a-HP4A) sample C-1 after two thermal expansion runs in argon to $950^{\circ} \mathrm{C}$. 


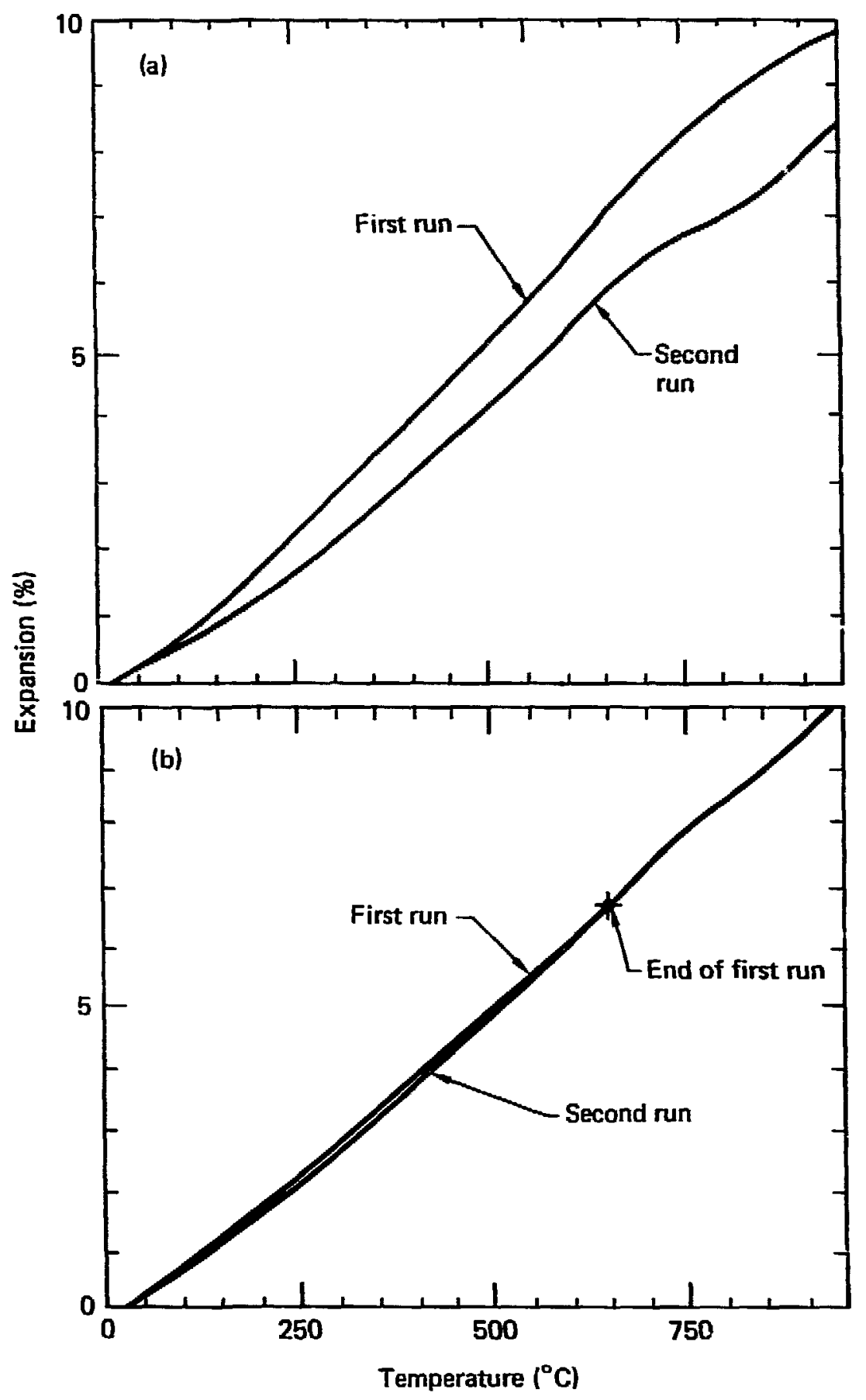

Figure 20. Thermal expansion and thermal cycling effects of sample S20-S03a-HP4A as a function of temperature. (a) The first and second runs of test sample C-1 differ significantly, indicating that annealing occurred during the initial run. (b) Repeat of the runs in (a) except that c-2, the second test sample, was heated under argon to only $650^{\circ} \mathrm{C}$ in the initial run; in this case, no significant difference in the expansion behavior of runs 1 and 2 was observed. 
Table 18. Linear thermal expansion coefficients ${ }^{a}$ for Synroc $D$ composite ( S20-S03a-HP4A).

\begin{tabular}{|c|c|c|c|c|}
\hline \multirow{3}{*}{$\begin{array}{l}\text { Temperature } \\
\text { range }\left({ }^{\circ} \mathrm{C}\right)\end{array}$} & \multicolumn{4}{|c|}{ Expansion coefficient $\left(a \times 10^{6}\right)$} \\
\hline & \multicolumn{2}{|c|}{ Sample C-1 } & \multicolumn{2}{|c|}{ Sample $C-2^{b}$} \\
\hline & Test No. 1 & Test No. 2 & Test No. 1 & Test No. 2 \\
\hline $22-79.8$ & 6.92 & 5.71 & 8.65 & 6.23 \\
\hline $22-207.1$ & 9.19 & 6.81 & 9.40 & 8.70 \\
\hline $22-319.3$ & 9.92 & 7.90 & 9.89 & 9.42 \\
\hline $22-425.0$ & $10 . ! \cdot 7$ & 8.51 & 10.15 & 9.80 \\
\hline $22-526.8$ & 10.72 & 8.82 & 10.36 & 10.16 \\
\hline $22-625.7$ & 11.07 & 9.34 & 10.40 & 10.40 \\
\hline $22-721.4$ & 11.22 & 9.37 & - & 10.74 \\
\hline $22-814.3$ & 11.15 & 8.99 & - & 10.68 \\
\hline $22-949.0$ & 10.57 & 9.06 & - & 10.82 \\
\hline
\end{tabular}

a Two tests were performed under an argon atmosphere on each sample. Testing was performed by R. C. Lum. Mechanical Engineering Department, Lawrence Livermore National Laboratory, Livermore, CA.

$\mathrm{b}$ Test No. 1 was taken to $650^{\circ} \mathrm{C}$ only.

As a test to explore the temperature dependence of stress relief, the second specimen, $\mathrm{C}-2$, was heated to only $650^{\circ} \mathrm{C}$ in the first run. As shown in Fig. 20b, there was no significant difference in the expansion behavior of runs 1 and 2. Also, the expansion coefficients for both runs 1 and 2 are nearly the same as the initial run for sample $\mathrm{C}-1$.

These results indicate that in the temperature region of 650 to $950^{\circ} \mathrm{C}$, internal stresses can be relieved and that cooling rates in this temperature interval are important in the preparation of a stress-free Synroc $D$ waste form of this composition. We believe that these data indicate the presence of a strained glass matrix in our Synroc D composite waste form. In an earlier report, ${ }^{28}$ we reported a nominal $25-v o 1 \%$ nepheline phase in Synroc D, and there is a strong likelihood that some of this nepheline phase may not have fully crystallized.

THERMAL CONDUCTIVITY

The thermal conductivity of S21-S18 composite Synroc D was measured at room temperature using a thermal comparator. In this method, the cooling rate 
of Synroc $D$ is determined by touching the surface of the sample with the $t$ ip of a heated probe. This rate is then compared to those of standard materials of known thermal conductivity. The details of this method were covered in an earlier report ${ }^{29}$ in which the thermal conductivity of Synroc $B$ was given as $2.0 \mathrm{~W} / \mathrm{m}-\mathrm{K}$.

A large sample of $521-518$ with a polished surface was used for these tests. Nine determinations gave an average value of $1.7 \pm 0.2 \mathrm{~W} / \mathrm{m}-\mathrm{K}$ for Synroc D.

\section{MICROHARDNESS}

We measured the Knoop microhardness of both $\mathrm{Sl} 18$ hollandite as single-phase material and the combined S2I-S18 Synroc D composite. In the latter case, measurements were made at edge and center locations to assess sample homogeneity. Three indenter loads $(50,100$, and $500 \mathrm{~g})$ were used in the evaluation to assess loading effects. Table 19 lists the mean values and calculated errors. The hardness typically decreases with increasing load for all samples. We found no significant difference between the edge and center values of two S2l-S18 samples nor any difference in hardness between the

Table 19. Microhardness of hollandite (S18) and Synroc D composite (S21-S18).

\begin{tabular}{|c|c|c|c|c|}
\hline \multirow{2}{*}{$\begin{array}{l}\text { Sample } \\
\text { number }\end{array}$} & \multirow{2}{*}{$\begin{array}{l}\text { Metallo- } \\
\text { graph } \\
\text { number }\end{array}$} & \multicolumn{3}{|c|}{ Microhardness $\left(\mathrm{kg} / \mathrm{mm}^{2}\right)^{b}$} \\
\hline & & $\mathrm{HKN}_{50}$ & $\mathrm{HKN}_{100}$ & $\mathrm{HKN}_{500}$ \\
\hline $\begin{array}{l}\text { Holland ite } \\
\text { S18-HP3A }\end{array}$ & 2450 & $959 \pm 23$ & $841 \pm 6$ & $774 \pm 5$ \\
\hline $\begin{array}{l}\text { Synroc D } \\
\text { S21-S18-HP8A }\end{array}$ & $\begin{array}{l}2466 \\
\text { (center) }\end{array}$ & $953 \pm 20$ & $867 \pm 25$ & $689 \pm 21$ \\
\hline $\begin{array}{l}\text { Synroc D } \\
\text { S21-S18-HP 12A }\end{array}$ & $\begin{array}{l}2472 \\
\text { (edge) }\end{array}$ & $941 \pm 24$ & $869 \pm 13$ & $701 \pm 10$ \\
\hline Synroc BC & $\begin{array}{l}\text { (center) } \\
\text { (edge) }\end{array}$ & $\begin{array}{l}1109 \pm 13 \\
1079 \pm 35\end{array}$ & $\begin{array}{r}1017 \pm 10 \\
1028 \pm 9\end{array}$ & $\begin{array}{l}875 \pm 21 \\
884 \pm 37\end{array}$ \\
\hline
\end{tabular}

a Metallographic filing number. Measurements were made by Al Ulrich.

b Error calculated as the standard deviation from the average of three values.

c Reference 27. 
single-phase hollandite (S18) and the composice vaste form (S21-S18) after hollandite additions.

Table 19 also shows the wicrohardness values of Synroc B taken from an earlier report. 29 synroc $B$ is significantly harder than synroc $D$. This is

not surprising since the other mechanical properties reported for Synroc $\mathrm{B}^{26}$ were about $50 \%$ greater than Synroc D properties.

\section{LEACHING CHARACTERISTICS}

Bazan has already presented leaching data on $\mathrm{S} 21-\mathrm{S} 18$ composite, $^{28}$ and, in Ref. 34, he gives additional detailed CLT leach results on all of the Synroc D samples covered in this document.

We have only sumnarized some of the data, which are given in Tables 20 and $21 .^{34}$ In Table 20 , we chose to 1 ist our high-temperature $\left(150^{\circ} \mathrm{C}\right)$ leaching data for strontium, cesium, and uranium in deionized water for all waste forms. These data were taken using a MCC-3 type test in which hot-pressed monoliths were crushed and sized to 150-300 $\mu$ m. A mean equivalent spherical diameter was used to calculate surface areas for determining leach rates (LR) normalized to the initial elemental concentration. Leach rates are given for each day in three successive days of testing.

In Table 21, we have listed only the 28 day normalized elemental LR for MCC-l cesting at $90^{\circ} \mathrm{C}$. For these experiments, unpolished monoliths were tested and geometric surface areas were used to calculate leach rates. Leaching data for three leachants (deionized water, silicate water, and salt brine) are reported.

Figure 21 shows monolithic leaching samples after leaching for s2 1-S18. Before leaching, core-drilled cylinders were wax mounted on a metal rod. Thin disks about 3 mo thick were then sliced with a diamond saw. Finally, the diaks were cut again to give the proper geometric area for the leach tests. The surfaces of composite samples were tested in both the unpolished and polished state. All samples exhibited excellent structural integrity after testing. 
Table 20. xcc-3-type ${ }^{a, b}$ static leach rates ${ }^{c}$ on crushed Synroc D at $150^{\circ} \mathrm{C}$ using deionized water.

Synroc D waste form

Initial concentration in Synroc D (wt $z$ )

Strontium

Cesium

Uranium

S2 1-518-HPBA

S29-HP8A

S26-SAN7A

0.14

0.23

1.3

0.15

0.22

1.4

S30-HP3A

0.15

0.23

4.2

S3 1-HP IA

0.19

0.22

4.2

0.029

0.046

0.24

\section{Leach rate $(L R)\left(g / m^{2} \cdot d\right)$}

\begin{tabular}{|c|c|c|c|c|c|c|c|c|c|}
\hline \multirow{2}{*}{$\begin{array}{l}\text { Synroc D } \\
\text { waste form }\end{array}$} & \multicolumn{3}{|c|}{ Strontium } & \multicolumn{3}{|c|}{ Cesium } & \multicolumn{3}{|c|}{ Uranium } \\
\hline & Day 1 & Day 2 & Day 3 & Day 1 & Day 2 & Day 3 & Day 1 & Day 2 & Day 3 \\
\hline S21-S18-HP8A & 0.14 & 0.15 & 0.16 & 1.85 & 1.10 & 0.79 & $<0.007$ & $<0.007$ & $<0.007$ \\
\hline $\begin{array}{l}\text { S29-HP8A } \\
\text { S26-SAN7A } \\
\text { S30-HP3A } \\
\text { S31-HP 1A }\end{array}$ & $\begin{array}{l}0.26 \\
0.10 \\
0.53 \\
0.40\end{array}$ & $\begin{array}{l}0.24 \\
d \\
0.48 \\
0.44\end{array}$ & $\begin{array}{l}0.30 \\
d \\
0.48 \\
d\end{array}$ & $\begin{array}{l}3.73 \\
0.46 \\
1.87 \\
3.97\end{array}$ & $\begin{array}{l}0.74 \\
d \\
1.20 \\
2.35\end{array}$ & $\begin{array}{l}0.51 \\
d \\
1.20 \\
d\end{array}$ & $\begin{array}{l}<0.008 \\
d \\
d \\
d\end{array}$ & $\begin{array}{l}<0.008 \\
d \\
d \\
d\end{array}$ & $\begin{array}{l}<0.008 \\
d \\
d \\
d\end{array}$ \\
\hline
\end{tabular}

a Leaching studies were done by $C$. Bazan and S. McLean.

b Crushed size range was 150-300 $\mu \mathrm{m}$. A geometric surface area (SA) of $0.0068 \mathrm{~m}^{2} / \mathrm{g}$ for leach-rate calculations was derived using a mean spherical diameter of $225 \mathrm{\mu m}$ and a density of $3.94 \mathrm{~g} / \mathrm{cm}^{3}$.

c The leach rates (LR) were normalized for each elemental mass fraction according to

$L R=\frac{M_{i}^{o}}{f_{i}^{\circ} \cdot S A^{\circ}(1 \text { day })}$

where

$M_{i}^{\circ}$ is the elemental mass loss (in $g$ ) during each day $(1,2$, and 3 ) of leaching,

$f_{i}^{\circ}$ is the initial mass fraction of element,

$\mathrm{SA}$ is the geometric surface area $\left(\mathrm{m}^{2}\right)$.

d Not analyzed. 


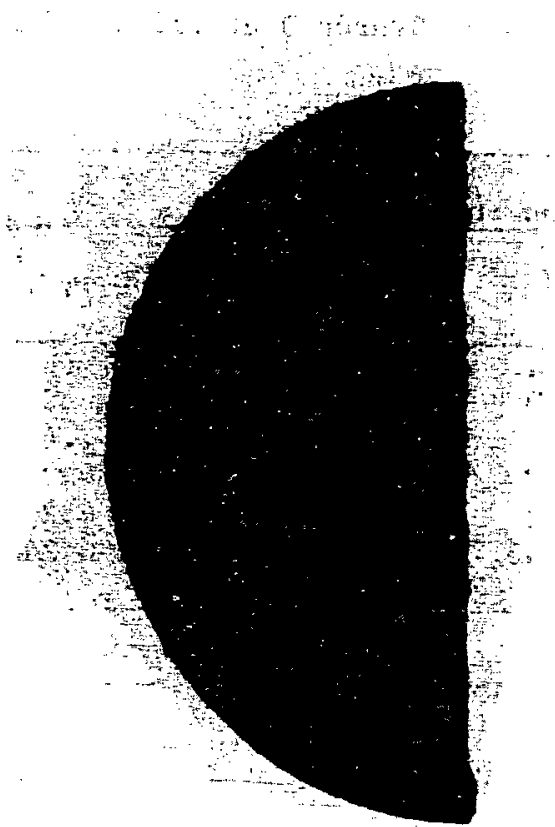

(a)

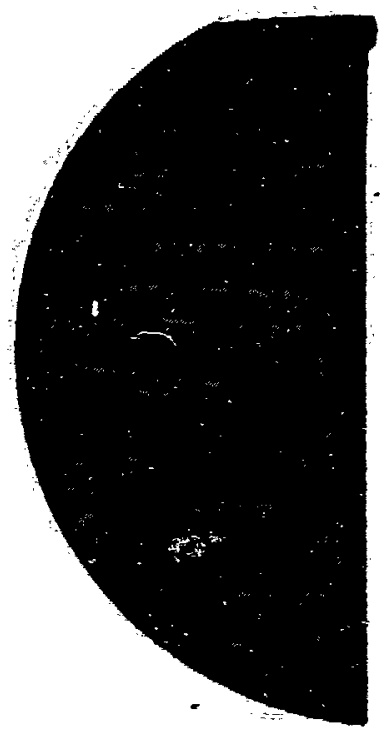

(b)

Figure 21. Monolithic leaching samples (S21-S18) after leaching for 28 days at $90^{\circ} \mathrm{C}$ (magnified $5 x$ ). (a) $521-518-H P 9 A$ after leach testing; unpolished, silicate solution. (b) S21-S18-HP8A after leach testing; polished, deionized water.

Table 21. MCC-1 static leach rates ${ }^{a, b}$ on Synroc $D$ monoliths ${ }^{c}$ in deionized water, silicate water, and brine.

\begin{tabular}{|c|c|c|c|c|c|c|c|c|c|}
\hline \multirow{3}{*}{$\begin{array}{l}\text { Synroc D } \\
\text { waste form }\end{array}$} & \multicolumn{9}{|c|}{ Leach rate $(L R)\left(g / m^{2} \cdot d\right)$} \\
\hline & \multicolumn{2}{|c|}{ Deionized } & water & \multicolumn{3}{|c|}{ Silicate water $^{e}$} & \multicolumn{3}{|c|}{ Brine $^{\bar{f}}$} \\
\hline & $\mathbf{S r}$ & Cs & $\mathbf{U}$ & Sr & Cs & $\mathrm{U}$ & $\mathrm{Sr}$ & Cs & $\mathbf{U}$ \\
\hline S21-518 & 0.35 & 0.11 & 0.00019 & 0.06 & 0.11 & 0.00016 & $<0.2$ & 0.09 & $\mathbf{g}$ \\
\hline S29 & 0.38 & 0.79 & 0.00011 & 0.099 & 0.54 & 0.00034 & $<0.1$ & 0.45 & $\$ 0.00025$ \\
\hline S26-SAN7A & 0.23 & 0.11 & $\mathbf{g}$ & 0.05 & 0.10 & $\mathbf{g}$ & $<0.7$ & $<0.1$ & g \\
\hline \$30 & 0.56 & 0.80 & g & 0.13 & 0.20 & 8 & 0.05 & 0.17 & $g$ \\
\hline S31-HP1A & $<0.13$ & 3.86 & g & $<0.13$ & 2.95 & 8 & $<3.2$ & 1.50 & 8 \\
\hline
\end{tabular}

a Leaching studies were done by $\mathrm{C}$. Bazan and S. Mchean.

$b$ Hormalized leach rates were calculated according to Table 20 , footnote $c$.

c Monoliths were sliced using a diamond saw from core drills taken from larger 7.62-cm-diam CLT samples having geometric surface areas (SA) of $400 \mathrm{~mm}^{2}$ and leachant volumes of $10 \mathrm{~cm}^{3}$.

d Samples were leached 28 days at $90^{\circ} \mathrm{C}$.

e Simulated silicate ground water (

f Salt brine containing sodium, potassium, and magnesium chlorides.

8 Not analyzed. 
1. Strategy Document. Long-Term High Level Waste Technology Program, Savannah River Laboratory, Aiken, SC, DOE/SR-WH-79-3, Rev. 5/81 (May 1981).

2. Alternatives For Long-Term Management of Defense High-Level Radioactive Waste, Energy Research and Development Administration, Savannah River Plant, Aiken, SC, vol. 1, ERDA 77-42/1 (May 1977).

3. J. A. Stone, S. T. Goforth, and F. K. Smith, Preliminary Evaluation of Alternate Forms For Immobilization of Savannah River Plant High-Level Waste, Savannah River Laboratory, Alren, SC, DP-1545 (Dec. 1979).

4. A. E. Ringwood, W. Sinclair, and G. M. McLaughlin, Nuclear Waste Immobilization, Lawrence Livermore National Laboratory, Livermore, CA, UCKL-15147 (1979).

5. J. A. Stone, Separation of SRP Waste Sludge and Supernate, Savannah River Laboratory, Aiken, SC, DP-1441 (Nov. 1976).

6. J.A. Stone, J. A. Kelley, and T. S. McMillan, "Sampling and Analysis of SRP High-Level Waste Sludges," Savannah River Laboratory, Aiken, SC, DP-1399 (Aug. 1976).

7. T. H. Gould, Jr., Savannah River Laboratory, Aiken, SC, private communication (June 5, 1980).

8. J. D. Tewhey, Lawrence Livermore National Laboratory, Livermore, CA, private communication (July 9, 1980).

9. J. A. Stone, Program Plan: Comparative Leach Testing of Alternate Waste Forms, Savannah River Laboratory, Aiken, SC, private communication (Oct. 17, 1980).

10. M. J. Plodinec, Development of Glass Composition for Imobilization of SRP Waste, Lawrence Livermore National Laboratory, Livermore, CA, DP-1517, February 1979.

11. P. B. Macedo, D. C. Tran, J. H. Simmons, M. Saleh, A. Barkatt, C. J. Simmons, N. Lagakos, and E. DeWitt, "Porous Glass Matrix Method for Encapsulating High-Level Nuclear Wastes," in Ceramics in Nuclear Waste Management (American Ceramics Society, Cincinnati, OH), CONF-730420 (1979), p. 321 .

12. G. J. McCarthy, "Crystalline Ceramics from Defense High-Level Wastes," Nuc 1. Tech. 44, 451 (1979). 
13. A. E. Ringwood, S. E. Kesson, and N. G. Ware, "Immobilization of US Defense Nuclear Wastes Using SYNROC Process," Scientific Basis for Nuclear Waste Management, Vol. 2 (Plenum Press, New York, NY, 1980), P. 265.

14. J. M. Rusin, M. F. Browning, and G. J. HcCarthy, "Development of Multibarrier Nuclear Waste Forms," Scientific Basis for Nuclear Waste Management, Vol. 1, G. J. McCarthy, Ed. (Plenum Press, New York, NY, 1979), p. 169 .

15. W. J. Lackey, P. N. Angelini, F. L. Layton, D. P. Stinton, and J. S. Vavruska, "Sol-Gel Technology Applied to Glass and Crystalline Ceramics," Waste Management ' 80 (in press).

16. J. G. Moore, G. C. Rogers, J. H. Paehler, and H. E. Devaney, "FuETAP (Formed Under Elevated Temperature And Pressures) Concretes as Hosts for Radioactive Wastes," in Proc. Intern. Symposium Ceramics in Nuclear Waste Management (American Ceramic Society and U.S. Department of Energy, Cincinnati, OH, April 30-May 2, 1979), U.S. Technical Information Center CONF-790420, p. 132 .

17. J. E. Mendel, H. A. Ross, D. M. Strachen, R. P. Turcotte, and J. H. Westsik, Jr., Materials Characterization Center: Horkshop on Leaching of Radioactive Waste Forms, Summary Report, Battelle Pacific Northwest Laboratory, Hanford, WA, PNL-3318/UC-70 (April 1980).

18. J. E. Mendel, R. D. Nelson, R. P. Turcotte, W. J. Gray, M. D. Merz, F. P. Roberts, W. J. Weber, J. H. Westsik, Jr., and D. E. Clark, Materials Characterization Center: A State-of-the-Art Review of Materials Properties of Nuclear Waste Eorms, Battelle Pacific Northwest Laboratory, Hanford, WA, PNL-3802/UC-70 (April 1981).

19. R. A. Van Konynenburg and M. W. Guinan, Radiation Effects in Synroc-D, Lawrence Livermore National Laboratory, Livermore, CA, UCRL-86679 Preprint ( 1981 ).

20. H. W. Newkirk, C. L. Hoenig, F. J. Ryerson, J. D. Tewhey, G. S Smith, C. S. Rossington, A. J. Brackmann, A. E. Ringwood, Status of SYNROC D Technology for Immobilizing U.S. Defense Wastes, Lawrence Livermore National Laboratory, Livermore, CA, UCRL-84395 Rev. 2 (1981).

21. F. Ryerson and G. Smith, Phase Characterization of SYNROC D, Lawrence Livermore National Laboratory, Livermore, CA (in press).

22. F. Ryerson, K. Burr, and R. Rozsa, Formulation Program for SYNROC D, Lawrence Livermore National Latoratory, Livermore, CA, UCRL-53237 (1982). 
23. J. W. Greig, and T. F. W. Barth, "The System, $\mathrm{Na}_{2} \mathrm{O} \cdot \mathrm{Al}_{2} \mathrm{O}_{3} \cdot 2 \mathrm{SiO}_{2}$

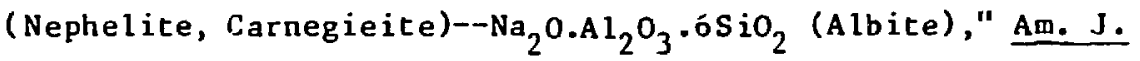

Sci., Sth Ser., 35A, 94 (1938).

24. R. G. Dosch, Sandia National Laboratories, Albuquerque, NM, private communications (DeC. 2, 1980 and Jan. 17, 1981).

25. R. B. Rozsa and C. L. Hoenig, SYNROC Processing Options, Lawrence

Livermore National Laboratory, Livermore, CA, UCRL-53187 (1981).

26. R. Lim, Aralytical Methods for the Determination of Some Elements and $\mathrm{Fe}^{+2}$ to $\mathrm{Fe}^{+3}$ Ratio in simulated Sludges and sYNROC Formulations,

Lawrence Livermore National Laboratory, Livermore, CA, UCID-19218 (1981).

27. C. Hoenig, R. otto, C. Bazan, R. Rozsa, J. Owens, R. Lim, and G. Smith, Preparation History and Analytical Results for SYNROC Powders:

Hollandite (S03), Nephel ine (S06), and SYNROC C (504, S05, S08, 509),

Lawrence Livermore National Laboratory, Livermore, CA, UCID-18845 (1980).

28. J. Campbell, C. Hoenig, F. Ryerson, F. Bazan, T. Wolery, M. Guinan,

R. Rozsa, R. Van Konynenburg, Immobilization of High-Level Defense Wastes

in SYNROC: An APpraisal of Product Performance, Lawrence Livermore

National Laboratory, Livermore, CA, UCRL-85913 (1981).

29. C. Hoenig, H. W. Newkirk, R. Otto, R. L. Brady, A. E. Brown, A. R. Ulrich, and R. C. Lum, The Mechanical and Thermophysical Properties of

Hot Pressed SYNROC B, Lawrence Livermore National Laboratory, Livermore, CA, UCRL-53143 (1981).

30. E. C. Snelling, Soft Ferrites--Properties and Applications (London Iliffe Books Ltd., London, 1969).

31. "Standard Test Methods for Flexural Properties of Plastics and Electrical Insulating Materials, Specification D-790-71" in Part 35, Plastics

General Test Methods, (American Society for Testing Materials,

Philadelphia, PA, 1979), p. 329.

32. "Standard Test Method for Compressive Strength of Fired Whiteware

Materials, Specification C-773-74," in Part 43, Electronics (American

Society for Testing Materials, Philadelphia, PA, 1979), pp. 15-18.

33. G. W. Morey, The Properties of Glass (Reinhold Publishing Corp., New York, NY, 1954), P. 267.

34. J. Campbell, C. Hoenig, F. Bazan, F. Ryerson, M. Guinan, R. Van

Konynenberg, and R. Rozsa, Properties of SYNROC-D: A State-of-the-Art

Review, Lawrence Livermore National Laboratory, Livermore, CA, JCRL-53240 (1982). 


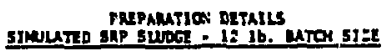

The dircals, shown bolow ar: thos! setwelly ubed for the proparation of

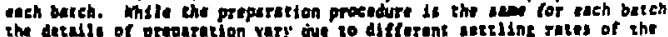

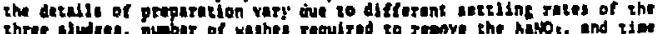
required to dry exch bateh.

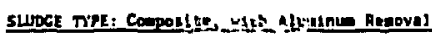

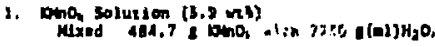

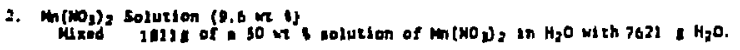

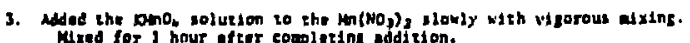

4. Nated $15.53 \mathrm{~L}$ of $\mathrm{H}_{2} \mathrm{O} 20$ ine $\mathrm{HnO}_{2}$ Alurty.

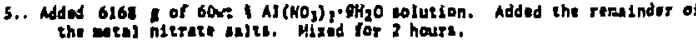

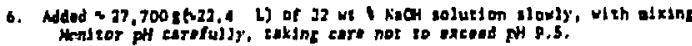

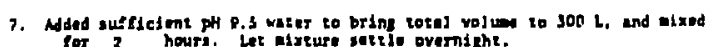

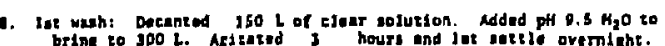

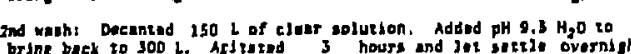
bring batk to 300

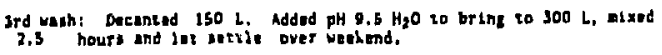
4th wesh: Decenead 230 $\mathrm{L}$.

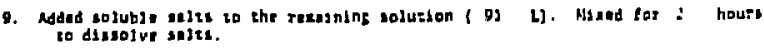

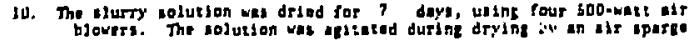

11. The dried sludge cer pulvertind in a ractry bell allt cor a hours, using

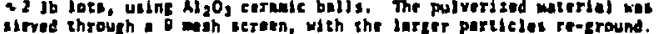

12. Vuejd frou SRL preparation

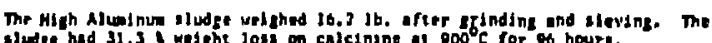

13. Coseulexion of Ney

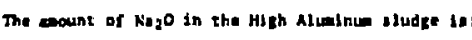

wish feetor: $\frac{170}{300} \times \frac{130}{300} \times \frac{250}{300} \times \frac{250}{5000} \times \frac{150}{500} \times \frac{130}{3000}=0.0135$

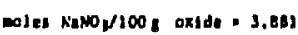

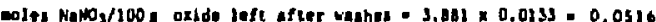

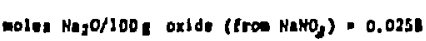

moles Nago/100: exidrt

$$
\begin{aligned}
& \text { - Kaso, }=0.0258 \\
& \text { - Naysto, }=0.0301 \\
& \text { - } \mathrm{NaHO}_{2}=0.000 \mathrm{~s} \\
& \text { - } \mathrm{Nn}_{2} \mathrm{C}_{2} \mathrm{O}_{4}=0.0001 \\
& \text { - } \mathrm{Ka}_{2} \mathrm{CO}_{3} \frac{0.00 \mathrm{l}}{.0615} \text { (BO.20 Ns, } \mathrm{CO}_{3} \text { edded) }
\end{aligned}
$$




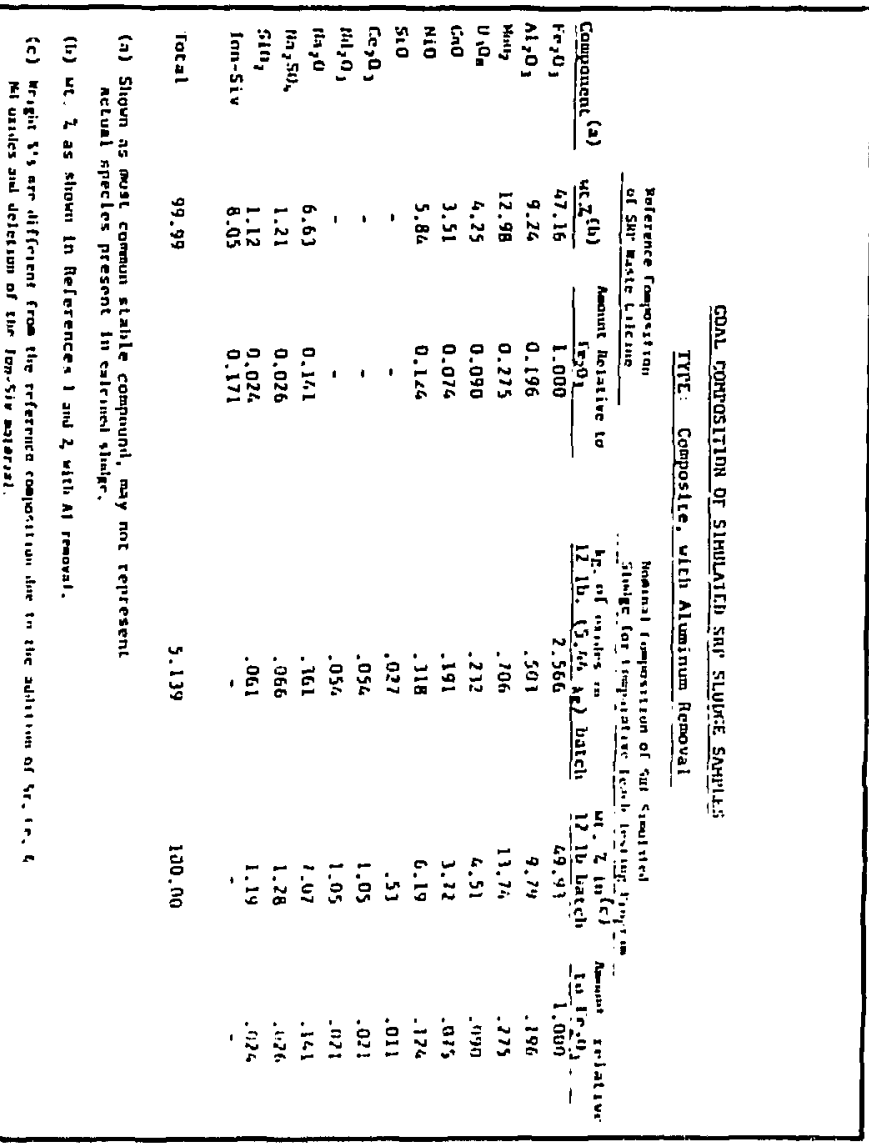

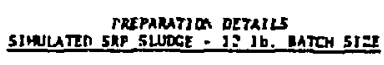

The dessls show belov are those actually used for the proparation of

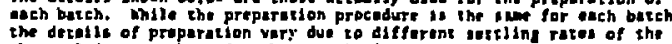

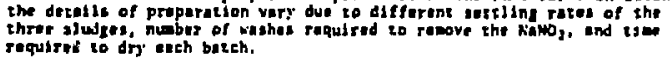

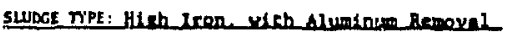

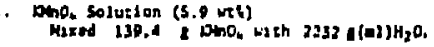

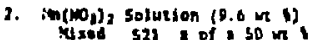

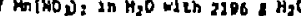

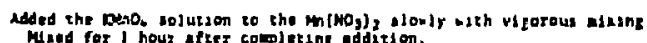

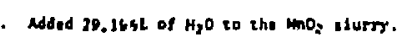

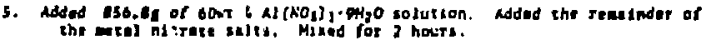

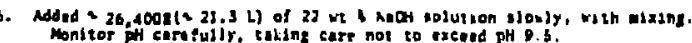

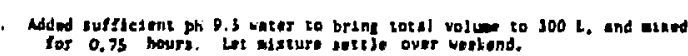

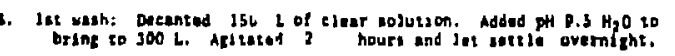

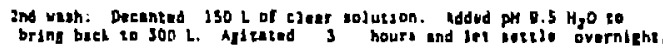

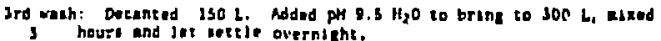

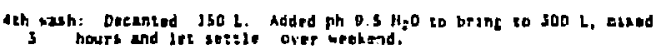
Sth sinsu: Decented $130 \mathrm{~L}$.

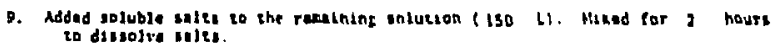

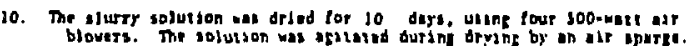


COAL COAPOSITION OF SIMULAIED SAP SLUDGE SAMPLES

TYCE: High Iron ulch Aiuelnue Resoval

\begin{tabular}{|c|c|c|c|c|c|}
\hline \multirow[b]{2}{*}{ Copponent (a) } & \multicolumn{2}{|c|}{$\begin{array}{l}\text { Eefereace Comostiton } \\
\text { of snp wasle Gicial }\end{array}$} & \multicolumn{2}{|c|}{ 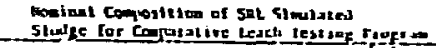 } & \multirow{2}{*}{$\begin{array}{l}\text { newol relative } \\
\text { cofe, fe }\end{array}$} \\
\hline & $w c . z^{(b)}$ & $\begin{array}{c}\text { Nount Iflative to } \\
\mathrm{F}_{22} \mathrm{O}_{1} \\
\end{array}$ & $\begin{array}{l}\text { 16. of axites } 10 \\
12 \text { 16. }(5.44 \text { (s) bately }\end{array}$ & 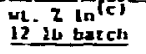 & \\
\hline $\mathrm{re} \mathrm{O}_{1}$ & 55.90 & 1.000 & 3.042 & 58.60 & 1.000 \\
\hline $\mathrm{Al}_{\mathrm{N}_{1} \mathrm{ON}_{2}} \mathrm{O}$ & $\begin{array}{l}1.29 \\
3.74\end{array}$ & $\begin{array}{l}0.023 \\
0.067\end{array}$ & $\begin{array}{l}-070 \\
.204\end{array}$ & $\begin{array}{l}1.35 \\
3.93\end{array}$ & $\begin{array}{l}.023 \\
.061\end{array}$ \\
\hline $\mathrm{H}_{1} \mathrm{O}_{2}$ & 12.98 & 0.232 & .706 & 13.60 & .232 \\
\hline$\Leftrightarrow 0$ & 3.80 & 0.068 & .207 & 3.98 & .068 \\
\hline 110 & 9.54 & 0.171 & .519 & 10.00 & $.1: 1$ \\
\hline $\operatorname{sio}$ & - & - & .021 & 0.52 & .099 \\
\hline $\mathrm{Cr}_{2} \mathrm{O}_{3}$ & - & - & .054 & 1.04 & .016 \\
\hline $\mathrm{M}_{2} \mathrm{O}_{3}$ & - & - & $.05 i$ & 1.04 & .018 \\
\hline $\mathrm{H}_{2}, 0$ & 6.75 & 0.085 & .259 & 4.99 & .n8s \\
\hline $\mathrm{Sta}_{\mathbf{3}} \mathrm{SO}$ & $0.50^{(d)}$ & $0.009^{(d)}$ & .027 & 0.52 & .009 \\
\hline sio, & $0.40^{(d)}$ & $0.007^{(a)}$ & .022 & 3.42 & . \\
\hline $\operatorname{lnn} \cdot 5 i^{\circ}$ & 8.00 & 0.163 & - & - & - \\
\hline
\end{tabular}

$\begin{array}{lrrr}\text { Total } & 100.90 & 5.191 & 99.99\end{array}$

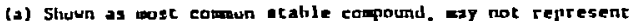
actual specles present in exlelinrs sliviles.

(b) we. $Z$ as glown in Reterences 1 and 2 with $\mathrm{Al}$ renaral.

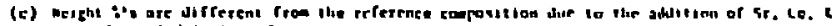

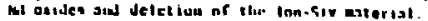

(d) Upper limik.

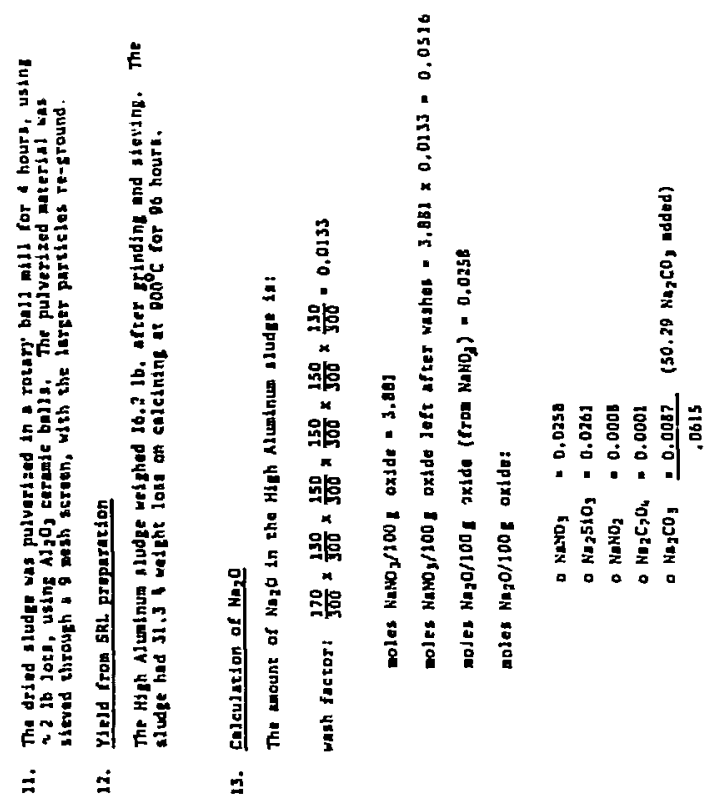




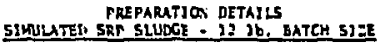

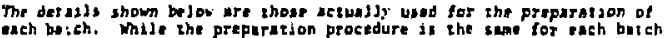

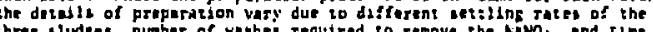
requised to disy wash bazch.

5LUDGE TPR: HSPh Aluminum, AS th Uluminum removel

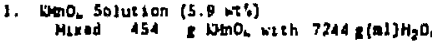

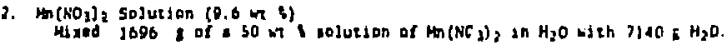

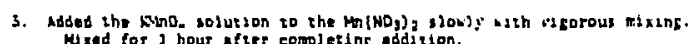

4. Ndad $6.0 \mathrm{~L}$ of $\mathrm{H}_{3} \mathrm{O}$ to the $\mathrm{HnO}_{2}$ Elurg

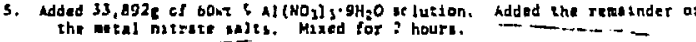

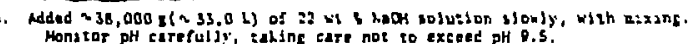

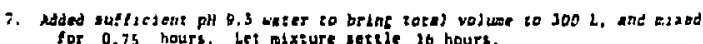

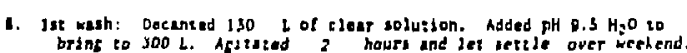

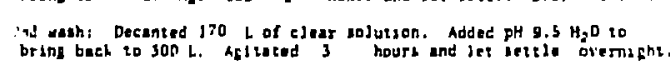

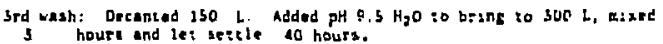

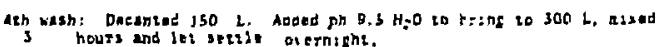

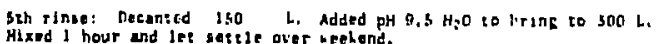
6sh wath: Desenesd $179 \mathrm{~L} \mathrm{HaO}$.

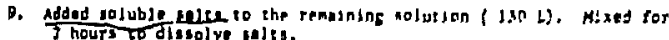

10. The elurry solution was dried fas 10 deys, using sla 500 -nats ayr
11. The cried sludge was pulverized 20 atary bels mill for a hours, wsing

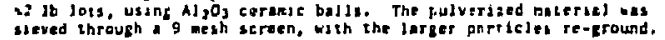

12. Vield fron SRL prupuration

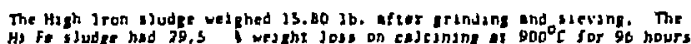

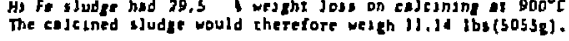

\section{1] Colculation of $\mathrm{Me}_{2} \mathrm{CO}_{2}$ iddation}

The seount of $\mathrm{Na}_{3} \mathrm{CO}_{3}$ added in Step 9 wal ealculnted al follows:

wash factor $=\frac{150}{300} \times \frac{150}{300} \times \frac{150}{300} \times \frac{150}{300} \times \frac{150}{300}=0.0313$

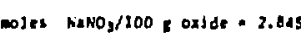

moles saNO $y / 100$ oxide efter washes = 2.045 \& 0.0313 0,0018

majes $k_{3}, 0 / 100 \sum$ Dxide $=4,0,0889 \cdot 0,0445$

Goll amount of Na, $0=0.0766$ moles/100 s oxidr.

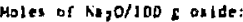

- Neros $\cdot 0.0445$

$0.54,510 \cdot 0.0008$

$0 \mathrm{KanO}=0.0010$

O $\mathrm{NH}_{2} \mathrm{C}_{2} \mathrm{O}+\mathrm{O}, \underline{0.0001}$

0.0526

G0.25 $\mathrm{xa}_{2} \mathrm{O}=0.0766$

$\underline{0.0528}$

.0:36 males hat 60,1700 g onide so and

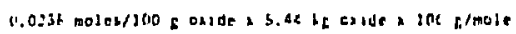

- $13 \mathrm{siz}_{\mathrm{i}}=\mathrm{Mn}_{3} \mathrm{CO}^{2}$ 
STAFthe MTERTus ros

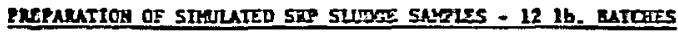

Cooporond Used

Khon

$\operatorname{tn}\left(\mathrm{FO}_{1}\right)_{3}$

$\mathrm{Al}(\mathrm{HO},)_{3}-9 \mathrm{H}_{2} \mathrm{O}$

Fe $\left(\mathrm{NO}_{3}\right)_{3} \cdot 91120$

$\mathrm{UO}_{2}\left(\mathrm{NO}_{1}\right)_{2} \cdot 6 \mathrm{ll}=\mathrm{O}$

$\mathrm{Ca}\left(\mathrm{NO}_{1}\right)_{2} \cdot 411, \mathrm{O}$

$\mathrm{HL}\left(\mathrm{HO}_{3}\right)_{2} \cdot 6 \mathrm{u}_{2} \mathrm{O}$

$\mathrm{Sr}\left(\mathrm{HO}_{3}\right)_{2}$

$\operatorname{Ce}\left(\mathrm{BO}_{3}\right)_{1} \cdot 6 \mathrm{H}_{2} \mathrm{O}$

$\mathrm{Hd}\left(\mathrm{HO}_{1}\right)_{3} .6 \mathrm{H}_{2} \mathrm{O}$

$\mathrm{HaOH}$

$\| \mathrm{ILStO}_{1}-9 \mathrm{I}_{2} \mathrm{O}$

$\mathrm{Iin}_{2} \mathrm{CO}_{3}$

HaxD,

Nis, $5 \mathrm{O}_{6}$

$\mathrm{Ha}_{3} \mathrm{C}_{2} \mathrm{O}_{4}$

\begin{tabular}{|c|c|c|}
\hline \multicolumn{3}{|c|}{ geancicy. } \\
\hline Cooposite & Iish Iron & 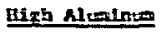 \\
\hline 486.7 & 139.4 & 458.0 \\
\hline 905.4 & 260.7 & 848.0 \\
\hline 3.700 .0 & 314.1 & 20.315 .0 \\
\hline 12.959 .3 & $15,396.0$ & 4.076 .0 \\
\hline 413.9 & 1.262 .0 & 3450 \\
\hline 804.5 & aro.c & 2210 \\
\hline 1.231 .3 & 2.020 .0 & 459.0 \\
\hline 55.6 & 55.7 & 53.7 \\
\hline 144.0 & 146.1 & $2<4.0$ \\
\hline 141.8 & 941.7 & 142.0 \\
\hline 6.100 .0 & $=6.000$ & 28.400 \\
\hline 288.4 & 102.1 & $\angle 0 \leqslant .0$ \\
\hline 190.4 & 137.2 & 50.2 \\
\hline 3.7 & 5.9 & 50 \\
\hline 65.9 & 2) 0 & 210 \\
\hline 0.7 & 0.1 & 0.1 \\
\hline
\end{tabular}

GOAL COAPOSITION OF SIRULAIED SAP SWUDE SANTLES

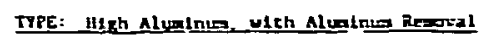

Deference Coopovithen or 5 gri teste Getc ibe

Crmonenen $(a)$ Fe, 0 , $\mathrm{Al}_{2} \mathrm{O}_{3}$

$\operatorname{lng}$

U,0.

CaO

NiO

Sro

$\mathrm{Ce}_{2} \mathrm{O}_{3}$

$\mathrm{Hu}_{2} \mathrm{O}_{3}$

$\tan _{3} \mathrm{O}$

$\mathrm{Na}_{2} \mathrm{SO}$

$\mathrm{SIO}_{2}$

Ion-Siv

Totel

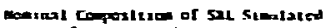

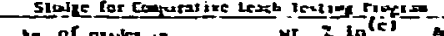

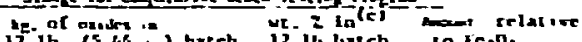

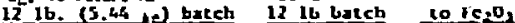

$0.006 \quad 15.55 \quad 1.000$

$2.763 \quad 5=60$

$.652 \quad 13.10 \quad .821$

$196 \quad 3.740 .241$

.053 $\quad: .05 \quad .065$

$118 \quad 2.34 \quad .147$

.027 .033

$\begin{array}{lll}.056 & 1.07 & .07\end{array}$

$.054 \quad 2.07 \quad .057$

$.200 \quad 4.12 \quad .251$

$027 \quad .37 \quad .033$

$\begin{array}{lll}.085 & 1.79 & .02\end{array}$

$-$

5.05299 .99

(a) Show an atet comon seble conound, wh not tepresent

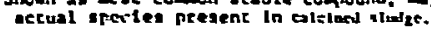

(b) ut. Z as show in Eaferences 1 and 2 eith at moorsl.

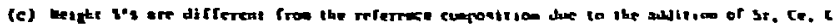

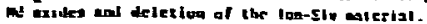

(d) Upper linke. 
APPENDIX B 
February 6, 1981

Or. John A. Stone

Suef Cycle Technology division

Alken, SC 29801

Dear Or. Stone:

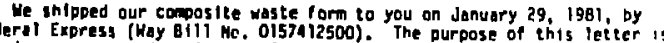
to give a sumary destription of the preparation and camposition of the to give somary description of the preparation and composition
waste form. A mire detalled report will follow at a later date.

We ish to enphas lze that these samples of Synrac do not necessarily ments may sstil be made in the overali performance of synroc as applied

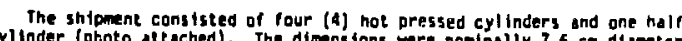
$2.5 \mathrm{~cm}$ he 1 ghe and the total mass was opgrontmately $1.911 \mathrm{~kg}$ gased on

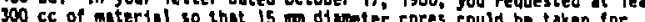

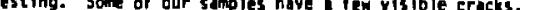
bel teve that - surfic lent number of cores can be taken in the untracked

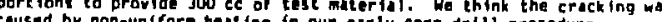
Cyinders mere secured to a cera of plete with loy melting wax or tor to core drilling by medns of a hot plate. When samples were hededed

A breakdoun of the nominal composit fons of as reectued 5al enmpos 110

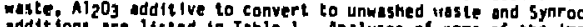

suleted the

Addielonel enclysos will be syallebile masuremens inderte closed ooresity in all samples. Mercury porast. metry messurements are in progress.
The preparation steps used were as follows:

STEP 1: MIXIMG AMO SPRAY DAYIMG

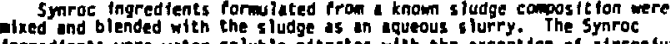
ingredients were water soluble nitral el with the exception of zirconium - Ir. titennium which was coded as pioment grade inatase ( $\mathrm{THO}_{2}$ ) and silica (S102) which was added as colloidal silices. The combined slurry ainture was blended for doout 16 hours. The slurry was then properly i proct.

SIEP 2: CALCIMATION AKD GRIMDIMG

The spray dried powder was I Irst air calcined at b500C for opproxlateiy if hourf to a constant we iglit. The powder was then redox calc In to on forf decualely reduced in aporoniastely $12-16$ hours ot $9650 \mathrm{C}$ and $\mathrm{CO}_{2} / \mathrm{CO}$

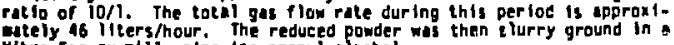

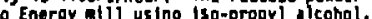

Monally grinding would not be necessury depending on the nature of - ifudge, ilielnated by the grinding step.

\section{STEP 3: HOT PRESSING}

The redox calcined powder was then blended nomogeneously with crushed

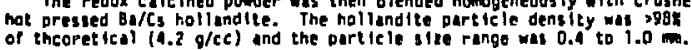

Hickel pouder was not added becaute the $\mathrm{Fe}^{42} / \mathrm{Fe}^{+3}$ rat lo had been

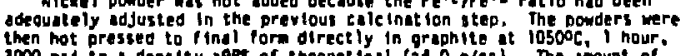

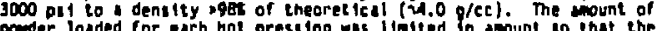
pouder loaded for etch hol pressing wit 


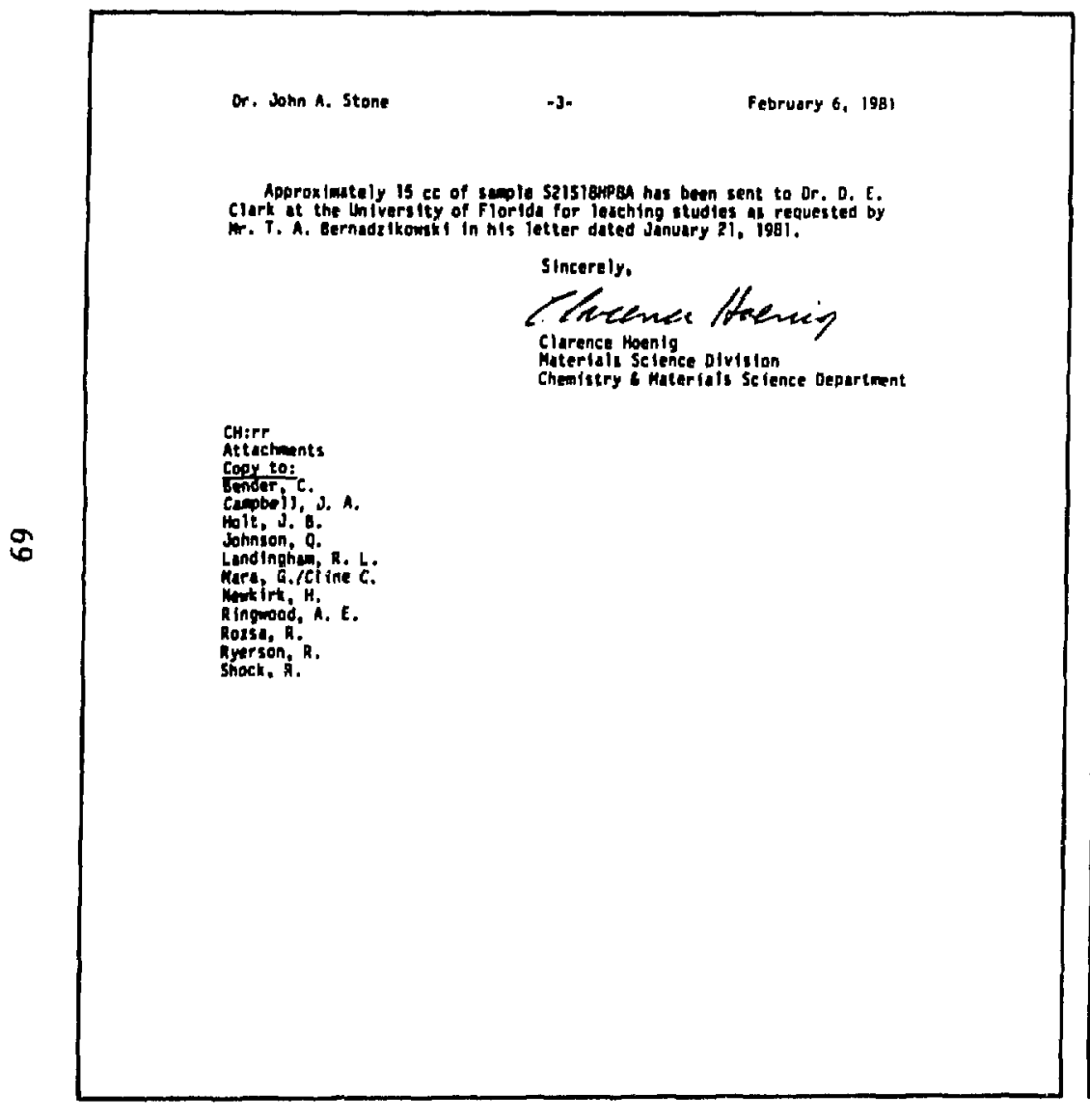

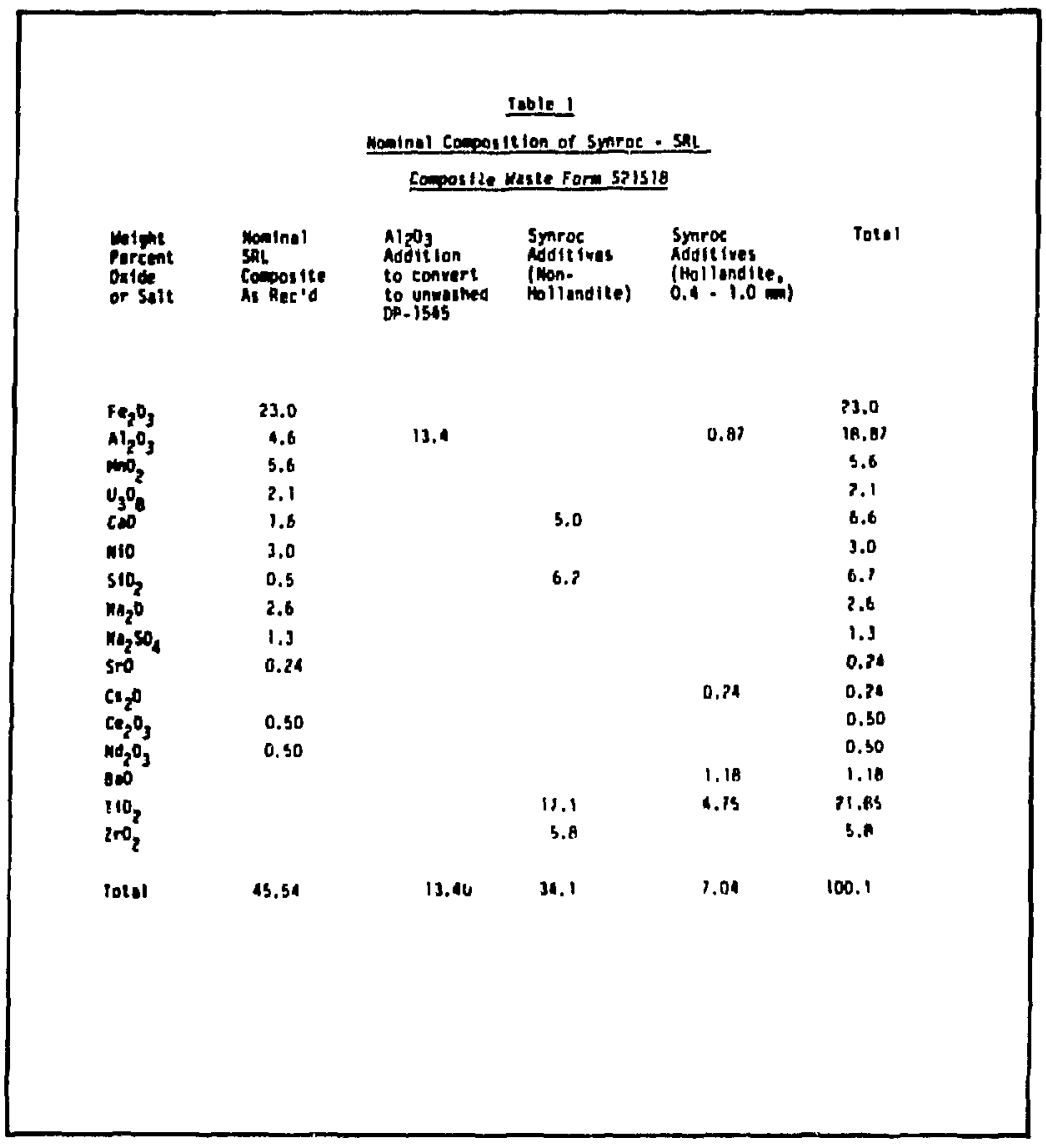


Teble 2

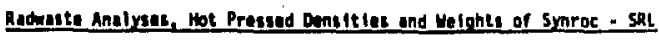
Comorite Wuste Forn 521518

\begin{tabular}{|c|c|c|c|c|c|}
\hline Suplo Mo. & (oright & $\begin{array}{l}\text { Tomersion }(1) \\
\text { Density } \\
(\mathrm{g} / \mathrm{cec})\end{array}$ & sto & $\underset{C_{320}}{\text { Weight }}$ & $\mathrm{V}_{3} \mathrm{O}_{\mathrm{B}}$ \\
\hline S215184PA & 178.38 & 3.938 & $\begin{array}{l}0.16 \\
0.16\end{array}$ & $\begin{array}{l}0.23(c) \\
0.21(E)\end{array}$ & $\begin{array}{l}1.5 \\
1.5\end{array}$ \\
\hline 52151E4G9A & 434.11 & 3.929 & 0.15 & 0.24 & 1.5 \\
\hline$\$ 215$ Iapian & 432.13 & 3.930 & 0.16 & 0.22 & 1.5 \\
\hline S21S18up 111 A & 131.98 & 3.910 & 0.13 & 0.26 & 1.5 \\
\hline 5215104 12A & 434.45 & 3.931 & 0.16 & 0.26 & 1.6 \\
\hline
\end{tabular}

1. Theoretical dens 1 ty is imen as $4.0 \mathrm{~g} / \mathrm{kc}$.

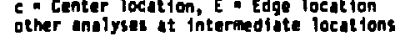

Pebruary 12, 1801

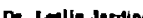

coratory

groo Bo. Caw Avenue

Dear Dr. Jurdiner

Under ceparate cover we are zending you semples of SY NHOC D for your brutle

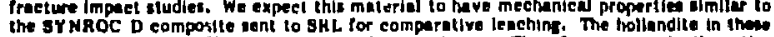

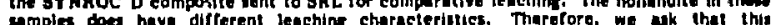
material nol be werd for any leaching studies.

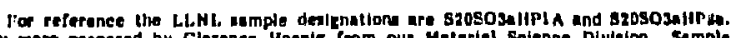
They were propared by clerence lloenif from our Material science Divation. Sampla Theoretical Density No. of Sampleat

Preperation

Bample Dealknations

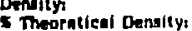
Mes of Bamples: Ho. of samplat

Preperation

\section{4hplA}

$9.98 \%$

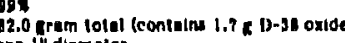
one "dingreler

somples hos presued in araphice die $11000 \mathrm{c} / \mathrm{s}$ minules/40no $\mathrm{mi}$

s20503a!p $2 A$

3.76

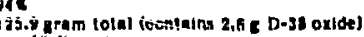

lour $1 / 2^{\text {n }}$ disminter

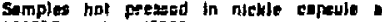
I050" C/Ono hut $/ 9000$ pal

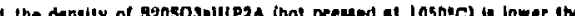

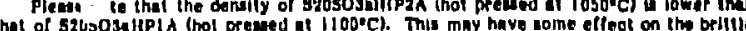
eroeture behavior of the materlat.

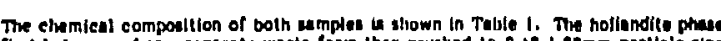

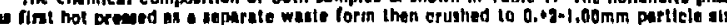
and added to the copostle alude for final hol preasing.

e will be anxinus to learn about the resulte of your atudy. Please feel free to eall

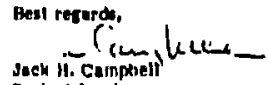

sach it. Carnpiath

Project Lander Porm Develooment Profect 

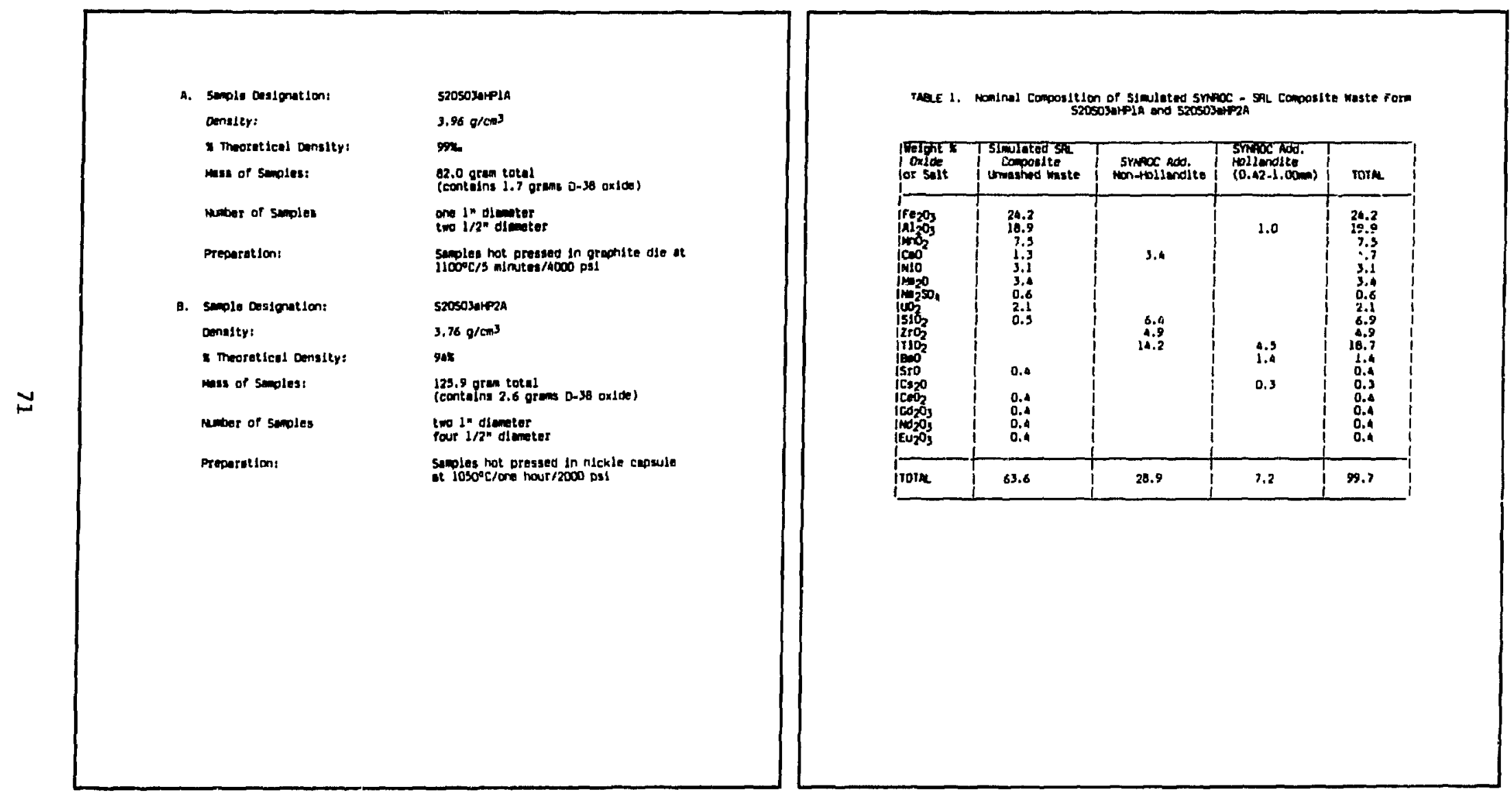
Dr, John A. Slone

Suvannah River Laboratory Alkan, SC 29801

Dear Johns

We shipped our hlgh Fe BYMROC wasth form to you on April 10, 1981 by Federal

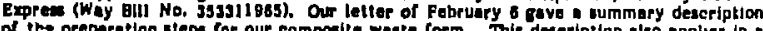
Tneral venes to our high po warle form There ape some exceptions, howeves thipment consisted of two hat presised oylinckeps. The dimensions wore nominally $7.8 \mathrm{~cm}$

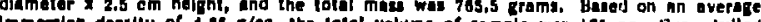
Immerzion densily of 4.36 a/ee, the lotal volume of sample way $173 \mathrm{ece}$. Cope drilled

The high Fe material has ollterent microstrueture than the composite waste form. Large graln boundarles were devaloped during the hat prossing nop using magnetic

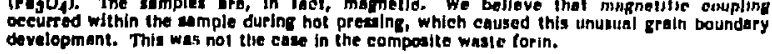

Our lenething studies do not ahow iny adverse effects due to this linge grain development. However, we have found that the inalepial has Jower strength then the composite waste rorm. This makes il more dirficult to propares somplem for teach testing.

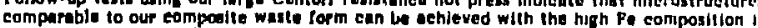
Pesist ance rather than Induction healline molhods ope used during hol pressing

$A$ brankdawn of the nouninal compoeltions af actsceived SRL composile waste

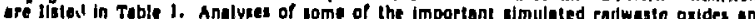

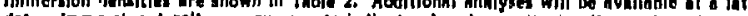
date. Immersion denelly measurementy indicale closed porosity in all semplat. Murcury
The preps. whon steps used were us followss

Scos it Mixily end Spray Drvagr

BYNROC ingredlents formulated from a known bludre composition were mixed and hlended wilh the aludze at an aqueous slurry. The SY NHOC ingedlents

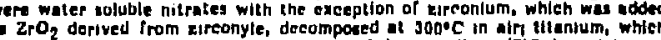
16 hours. The glupry wat then properly agiented to ensure tioniogeneous particle suspenalon and eprey dried al i $130^{\circ} \mathrm{C}$.

Siep 2: Calaination and Grindig:

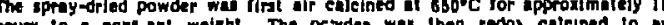

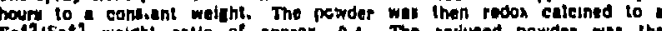

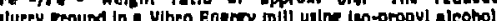

Normally, grindine would not be neceunry, depending on the nature of ine slucke. We round in preslminary hat pressing avaluation: of sprey drite by the trinding step.

\section{Sime 1: Hol Preaning}

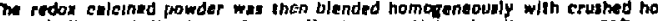

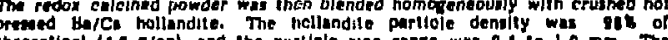

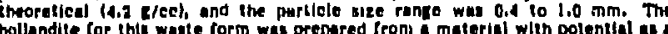

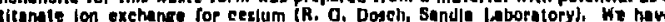

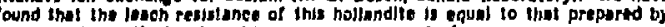
ine sprey dery melhod und usto in ouf remposite while form.

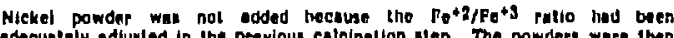
odequately sdjusted in the previlous cateination ntep. The powders were then hot preased to final form dimetly in traphlite of lazsec, i hp, 9000 pal, to

Gach Camplecte hom

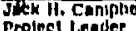

Mineral Wuste Forn Development Projeet 


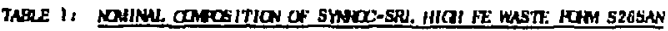

\begin{tabular}{|c|c|c|c|c|c|}
\hline $\begin{array}{l}\text { Molghe } \\
\text { Pareent } \\
\text { Orise } \\
\text { or Eult }\end{array}$ & 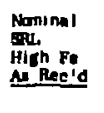 & 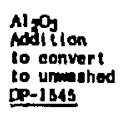 & 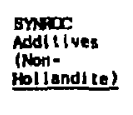 & 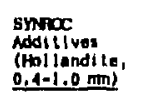 & Dotal \\
\hline $\mathrm{Fa}_{2} \mathrm{O}_{3}$ & 28.9 & - & . & - & 28.9 \\
\hline $\mathrm{Al} / 2 \mathrm{OJ}$ & 0.7 & 2.0 & 3.6 & 0.6 & 6.9 \\
\hline $\mathrm{mol}_{3}$ & 1.9 & . & - & - & 1.9 \\
\hline$u_{5} x_{8}$ & 0.7 & - & - & - & 6.7 \\
\hline$\infty$ & 1.3 & - & 0.0 & - & 2.3 \\
\hline No & 9.2 & - & - & - & 5.2 \\
\hline $\mathrm{SIO}_{3}$ & 0.2 & - & 4.2 & - & 4.4 \\
\hline$w_{20}$ & 1.9 & - & " & - & 1.9 \\
\hline $\mathrm{Nm}_{2} \mathrm{SO}_{4}$ & 0.3 & - & . & - & 0.3 \\
\hline Sro & 0.25 & - & - & - & 0.23 \\
\hline$a_{20}$ & . & - & - & 0.23 & 0.23 \\
\hline $\mathrm{gr}_{2} \mathrm{OO}_{3}$ & 0.30 & - & - & . & 0.50 \\
\hline Noy & 0.30 & - & - & - & 0.50 \\
\hline $8 m$ & - & - & - & 0.4 & 0.4 \\
\hline $\mathrm{THO}_{2}$ & - & - & 20.6 & 3.4 & 21.0 \\
\hline $2 \mathrm{rO}_{2}$ & $=$ & - & 10.1 & - & 10.4 \\
\hline TUThL. & 48. 35 & 7.0 & 44.8 & 1.05 & 99. \\
\hline
\end{tabular}

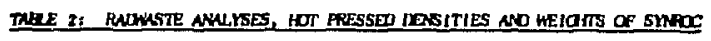
SPL HIOI FE WISTE POHA S26SN

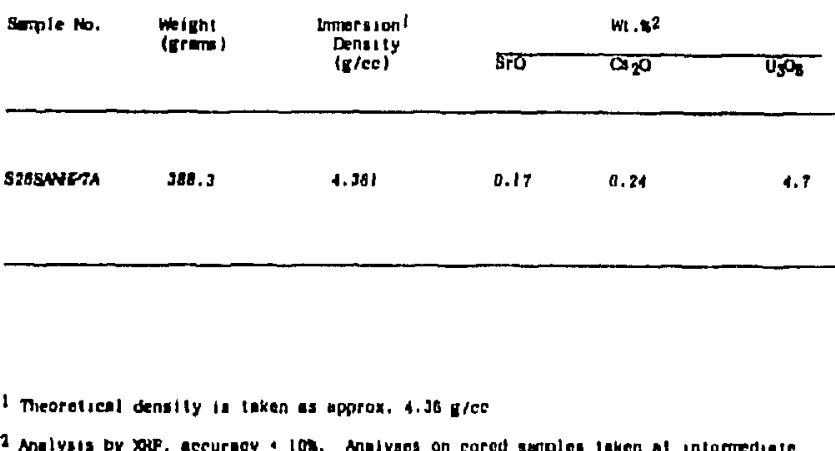

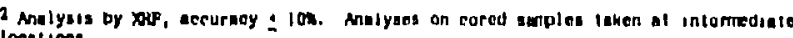
locstions. 
May 6, 1981

Mr. John A. Flone

E. L. dupont de Nemours and Company

Fuel Cycle 7 eer Laboratory Com

Puel Cycle Tectinoloty Division

Dear john:

Our work on a gecond SYNROC $\mathrm{D}$ campozition formulation in wheth cesium has deen thu herogremed very well.

Whieti cesium has

We unloped a single unmple S29HPas 10 you on May 6, 1081, by Federal Express". The dimensions were nominally $7.6 \mathrm{em}$ diameter $\times 2.0 \mathrm{~cm}$ nelght and the total mass was Weximately 230 grams.

We have taken two cors drills for our leaching studies. We had no difficulty coring

The nominel composittion of thit materlat is as tollows

\begin{tabular}{|c|c|c|}
\hline $\begin{array}{l}\text { WIs } \\
\text { Oxide or Sell }\end{array}$ & $\begin{array}{l}\text { SRL Cornpositv } \\
\text { (unwestred) }\end{array}$ & $\begin{array}{l}\text { SYNROC } \\
\text { Additives }\end{array}$ \\
\hline 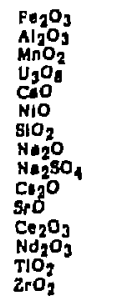 & 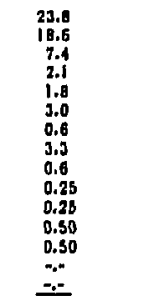 & 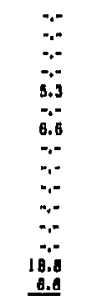 \\
\hline & 62.7 & 37.3 \\
\hline
\end{tabular}

ïr. J. A. Sione

May 6 , 1981

The preparation stops used were as tollowsi

Step is Mixing end Sproy Drying

SY KROC

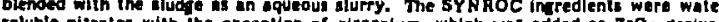
irome grade anatese ITLO, and silies IStO

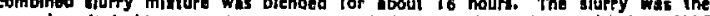
Slep z Calegnellon and Oriading

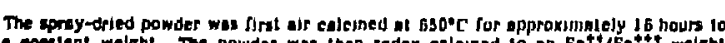
constant wely. The powder was in

\section{Stepe 2: Hol Pressing}

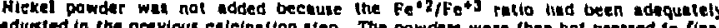

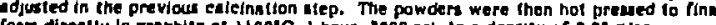

sincerely,

gack H. Campbellemal

sinck hi. cicmptoull

Projeat Lendar 
June 12. 1981

\section{Dr John A. Stong
E. l. duPorit de Nemoun and Company
Sevennnth Hiver Laboratory \\ Fual Cyolo Technology Division \\ Alken, South Carollna 29801 \\ Dear Johns}

We ghjpped for comparative leach testing our high AI SYNROC and a second high Fe SY NROC (both with in -itu cealum) by Federal Express (SRL No. NPMJ1240, Waybill No. 35331 5826) on Jisne A, 18B1.

The high Al anple (A3) HPI A) was nomlnally $7.8 \mathrm{em}$ diameter $\times 2.5 \mathrm{~cm}$ height with a cord iection removed for our samples. The total mass was 32 ud 8 and the nominal

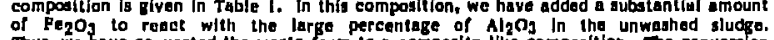
mus, we have converted the wasto form to a composilto-tike composition. The converston

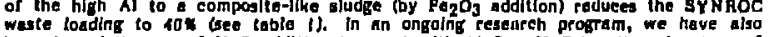
waste loading to 10\% (see table 1 . in $\mathrm{hn}$ ongoing researeh program, we have aiso guving higher waste loadings isD-EDN) due to its lower molecular weight and invariant

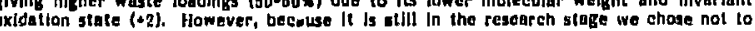
pespare the CLT sample in this mantier.

II has olso been broughe to our attention that in nll Ilxesllhood the sludge will be

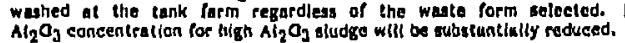

The nigh Fe stmple (SJoHP.iN) was taken from a large $15.2 \mathrm{em}$ dismater sample, hot pressed with restist ive heating enther than Induclive heating. The Iample was nominally $\mathrm{em} \times 4.5 \mathrm{~cm} \times 1.3 \mathrm{~cm}$. The Latal mass was $142.3 \mathrm{grams}$ and the nominal componttion is given In Table 2.

An earlier anmple S265A NHPPA (see iolter dated April 13, 1861) was hat pressed

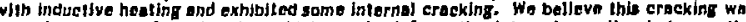
cawed by non-trifform healing which rasulted from the internal coupling between tis large emouni of magnetite in oroekling by visunl analyals. Thereforo, we bolieve we have solved the problem of eracklng axhiolted in umple SzeSANIIPTA.
Mr. J. A. Stane
Juns 12. S 1981

Page 2

The preparation Steps used for boin SJOHPiA and BSI HPI A were us followi Slep 1: Mixingend Spray Drying

SYMROC ingredients formulated from a known studgo composition wers mued and biended with the sludges as aqueous Mlurrics. The SYN ROC Ingredients were water TTO preparstions the Eireonium nitrate wat firat decomposed to oxide at J00"C to indure nitrote decomposilion. We have found this is no longer necesary and zirconium hes beton

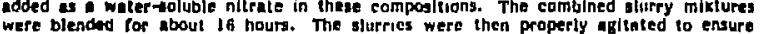
hamogeneous partlcle suspenslon and speay dreed at $130^{\circ} \mathrm{C}$.

Step_ 2i_caleination

The spray defed powders were first hir calcined al 658"C for approkimately if hours

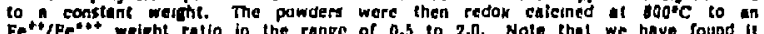

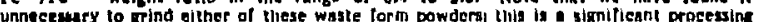
imprave ment over estler smmples.

Step 3 Hol Preving

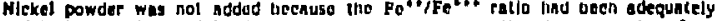

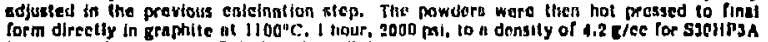

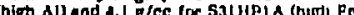

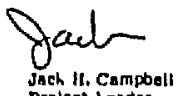

Propecr lenctor

JHorma

eq C. Hoenis 


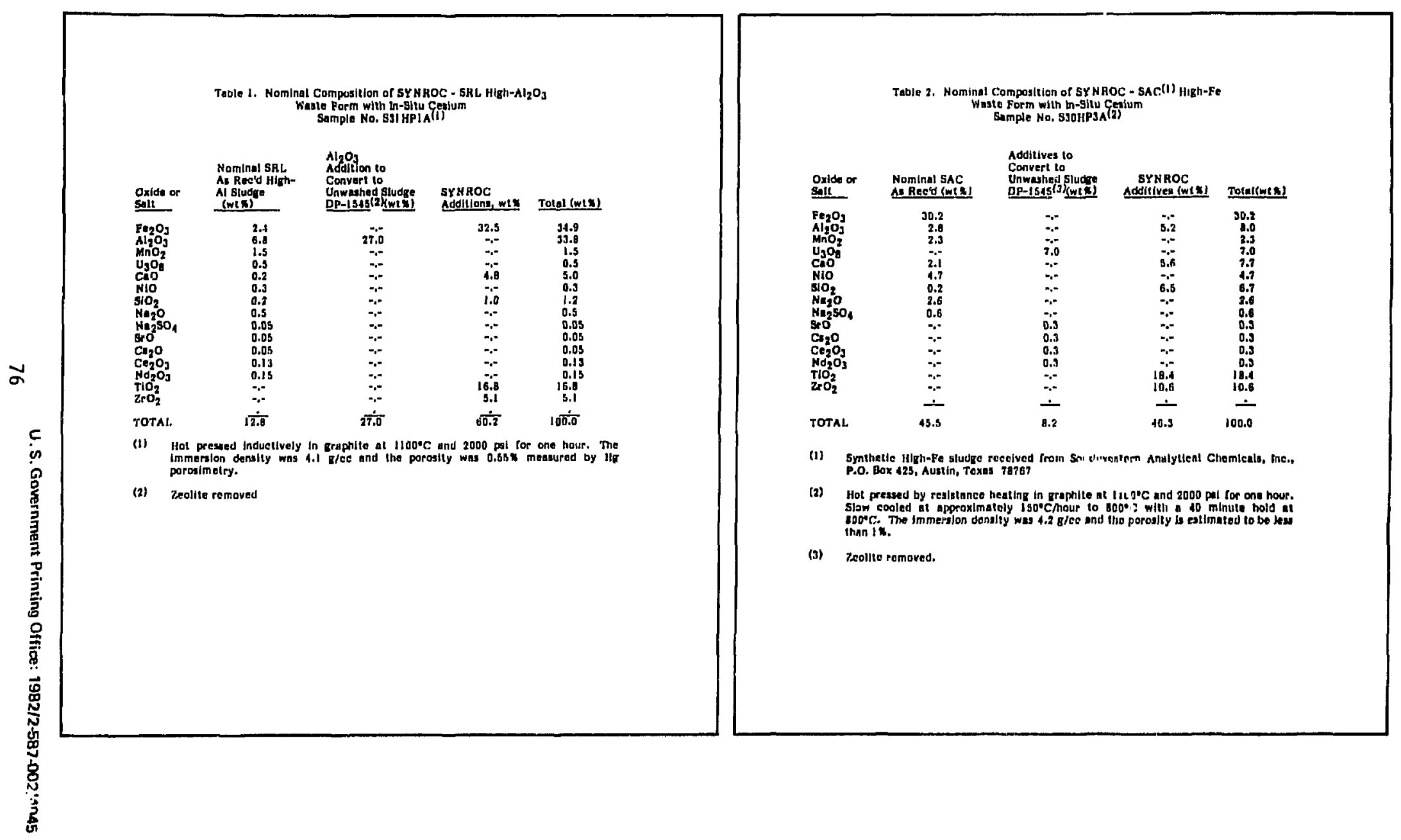

